\title{
Ligand Engineering for the Efficient Dye-Sensitized Solar Cells with Ruthenium Sensitizers and Cobalt Electrolytes
}

\author{
Sadig Aghazada, ${ }^{\dagger}$ Peng Gao, ${ }^{\dagger}$ Aswani Yella, ${ }^{\ddagger}$ Gabriele Marotta, ${ }^{\S, \perp}$ Thomas Moehl, ${ }^{\ddagger}$ Joël Teuscher, $\|$ \\ Jacques-E. Moser, "Filippo De Angelis, ${ }^{\S, \#}$ Michael Grätzel, ${ }^{\dagger}$ and Mohammad Khaja Nazeeruddin ${ }^{* \dagger}$ \\ ${ }^{\dagger}$ Group for Molecular Engineering of Functional Materials, École Polytechnique Fédérale de Lausanne (EPFL), CH-1950 Sion, \\ Switzerland \\ ${ }^{\ddagger}$ Laboratory of Photonics and Interfaces and "Group for Photochemical Dynamics (GDP), EPFL, CH-1015 Lausanne, Switzerland \\ ${ }^{\S}$ Computational Laboratory for Hybrid Organic Photovoltaics, Istituto CNR di Scienze e Tecnologie Molecolari, via Elce di Sotto 8, \\ I-06123 Perugia, Italy \\ ${ }^{\perp}$ Dipartimento di Chimica, Biologia e Biotecnologie, Università di Perugia, via Elce di Sotto 8, I-06123 Perugia, Italy

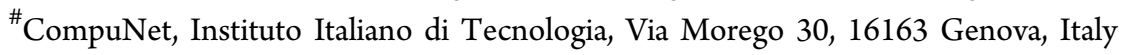

Supporting Information

ABSTRACT: Over the past 20 years, ruthenium(II)-based dyes have played a pivotal role in turning dye-sensitized solar cells (DSCs) into a mature technology for the third generation of photovoltaics. However, the classic $\mathrm{I}_{3}^{-} / \mathrm{I}^{-}$redox couple limits the performance and application of this technique. Simply replacing the iodine-based redox couple by new types like cobalt $(3+/ 2+)$ complexes was not successful because of the poor compatibility between the ruthenium(II) sensitizer and the cobalt redox species. To address this problem and achieve higher power conversion efficiencies (PCEs), we introduce here six new cyclometalated ruthenium(II)-based dyes developed through ligand engineering. We tested DSCs employing these ruthenium(II) complexes and achieved PCEs of up to $9.4 \%$ using cobalt $(3+/ 2+)$ based electrolytes, which is the record efficiency to date featuring a ruthenium-based dye. In view of the complicated liquid DSC system, the disagreement found between different characterizations enlightens us about the importance of the sensitizer loading on $\mathrm{TiO}_{2}$, which is a subtle but equally important factor in the electronic properties of the sensitizers.

\section{INTRODUCTION}

The global challenge to develop carbon-neutral renewable energy sources can be addressed by harnessing solar power using photovoltaics. ${ }^{1}$ As an alternative to conventional solar cells, third-generation photovoltaic devices with dye-sensitized solar cells (DSCs) at the forefront have been extensively studied. ${ }^{2}$ In standard DSCs, mesoporous $\mathrm{TiO}_{2}$ is sensitized by a ruthenium(II) complex or an organic dye, and $\mathrm{I}_{3}{ }^{-} / \mathrm{I}^{-}$is widely employed as the most effective redox couple. ${ }^{3,4}$ Congruence between the dye molecule chemisorbed on a mesoporous oxide and redox pair in the electrolyte in DSCs should be fine-tuned to obtain fast dye regeneration and ideally slow charge recombination. The present certified record power conversion efficiencies (PCEs) of up to $11.1 \%$ were achieved with $\mathrm{I}_{3}^{-} / \mathrm{I}^{-}$ and heteroleptic ruthenium dyes. ${ }^{5-7}$ However, regeneration of a ruthenium(II) complex by electron donation from the $\mathrm{I}_{3}^{-} / \mathrm{I}^{-}$ redox couple entails a loss of around $500 \mathrm{mV}$, with over 300 $\mathrm{mV}$ of that being directly related to the complicated sequence of reactions associated with the two-electron oxidation of iodide that do not involve the sensitizer molecule. ${ }^{8-10}$ The estimated lowest potential loss for the ruthenium metal complex/iodide system is around $750 \mathrm{mV}$, which limits the maximum obtainable conversion efficiency to $13.4 \%$., 11

To boost the efficiencies further, redox couples with a smaller loss in potential were introduced. Among the one-electron redox pairs, ${ }^{12,13}$ cobalt $(3+/ 2+)$ is the most promising for the following two reasons: (i) DSCs with organic dyes and cobalt electrolytes are more stable in comparison to the cells with other one-electron shuttles; ${ }^{14}$ (ii) it is possible to obtain cobalt complexes with various redox potentials just by ligand modification. $^{15,16}$ It is worth noting that the recent advances with copper $(2+/ 1+)$ phenantroline-based electrolytes may result in an improved performance. ${ }^{17,18}$ Contrary to the reduction of $\mathrm{I}_{3}^{-}$, the unwanted recapture of the conductionband electrons by the cobalt $(3+)$ complex is a simple oneelectron outer-sphere redox reaction, which can attain fast rates depending on the driving force, even though the cobalt $(3+/ 2+)$ self-exchange reaction is slow due to spin change. This is prominent, in particular, for conventional ruthenium dyes such

Received: April 7, 2016

Published: June 20, 2016 
as N3, N719, and N749. ${ }^{19-23}$ This caveat was ascribed to (i) the net negative charge on NCS-containing complexes causing columbic attraction between the positively charged cobalt complex and sensitizer, which results in adsorption of the cobalt complexes on the semiconductor surface ${ }^{24}$ and (ii) the quenching of the triplet metal-to-lignad charge-transfer $\left({ }^{3} \mathrm{MLCT}\right)$ state of ruthenium dyes by cobalt $(3+)$ species, giving rise to a lower photocurrent. ${ }^{25}$ To alleviate this problems, new ruthenium-free dye structures were accommodated with long alkyl or alkoxy chains to keep the redox pairs away from the surface. ${ }^{14,26,27}$ In this manner, PCEs of over $14 \%$ and open-circuit voltage higher than $1 \mathrm{~V}$ were achieved by employing bulky $\mathrm{D}-\pi-\mathrm{A}$ dyes with a cobalt-based electrolyte. ${ }^{28-31}$ A similar strategy was introduced for ruthenium dyes to improve their compatibility with the cobalt-based electrolyte. ${ }^{32-34}$

On the other hand, the bulky nature of the cobalt-based complexes compels one to use thinner mesoporous films in order to avoid mass-transport limitations of the photocurrent. This, in turn, requires the use of dyes with higher extinction coefficients. Ruthenium(II)-based sensitizers generally suffer from relatively low extinction coefficients, which motivated us to design and synthesize new cyclometalated tris-heteroleptic ruthenium(II) complexes. Through modification of the auxiliary ligands by attaching polyaromatic moieties, we can fine-tune the photophysical properties of the complexes, especially the extinction coefficient, and consequently the incident photon-to-current conversion efficiency (IPCE) in a device. It is known that the highest occupied molecular orbital (HOMO) in a cyclometalated ruthenium(II) complex involves the auxiliary ligand to a lesser degree than the cyclometalated ligand. $^{23,32}$ This provides a wide window for modification of the auxiliary ligand without destabilization of the HOMO's energy.

Here, we introduce six new tris-heteroleptic cyclometalated ruthenium(II) dyes (SA22, SA25, SA246, SA282, SA284, and SA285; Figure 1). All of these complexes possess the same

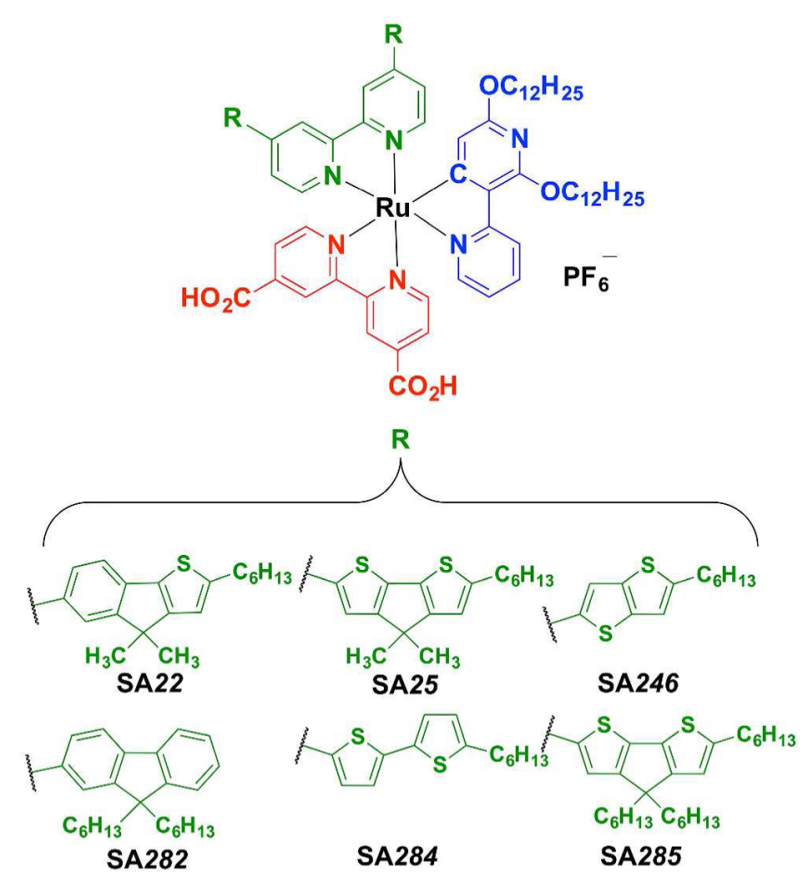

Figure 1. Molecular structures of cyclometalated ruthenium(II) complexes. anchoring ligand, 4,4'-dicarboxy-2,2'-bipyridine, and the same cyclometalated ligand as previously optimized. ${ }^{32}$ 2,2'-Bipyridines substituted in the 4 and $4^{\prime}$ positions with polyaromatic rings were used as auxiliary ligands. With these sensitizers, we systematically investigated the influence of the auxiliary ligand by optical and electrochemical measurement, theoretical calculation, transient absorbance spectroscopy (TAS), and electrochemical impedance spectroscopy (EIS).

In the presence of cobalt $(3+/ 2+)$ tris-phenantroline-based redox electrolytes, the highest PCE came from SA246, which possesses an insignificant absorption spectrum and the lowest electron lifetime. These contradictory results motivated us to unravel the critical parameters among the intricate effect of the kinds of factors. Through desorption experiments, we show that a proper substitution on the auxiliary ligands can dramatically increase the dye loading, which will play a decisive role in boosting the current density and quasi-Fermi level of $\mathrm{TiO}_{2}$ and lead to an overtaking efficiency.

\section{RESULTS AND DISCUSSION}

Synthesis. We have previously reported ${ }^{32}$ 2,6-didodecyloxy$3,2^{\prime}$-bipyridine as a superior cyclometalating ligand over 2,6dimethoxy-3,2'-bipyridine because of its ability to keep the redox shuttle away from the semiconductor surface. ${ }^{32}$ The synthesis of the auxiliary ligands was carried out through palladium(0)-catalyzed cross-coupling of $4,4^{\prime}$-dibromo-2,2' bipyridine with corresponding adducts of polyaromatic substituents. For the synthesis of tris-heteroleptic cyclometalated ruthenium(II) complexes, we adopted the procedures developed by Bomben et al., which starts from reacting the cyclometalating ligand with $\left[\mathrm{Ru}\left(\mathrm{C}_{6} \mathrm{H}_{6}\right) \mathrm{Cl}_{2}\right]_{2}$ or $[\mathrm{Ru}(p-$ cymene $\left.\mathrm{Cl}_{2}\right]_{2}$ (Scheme 1). ${ }^{36}$ After that, the intermediates were

Scheme 1. Synthesis of the Tris-heteroleptic Cyclometalated Ruthenium(II) Complexes

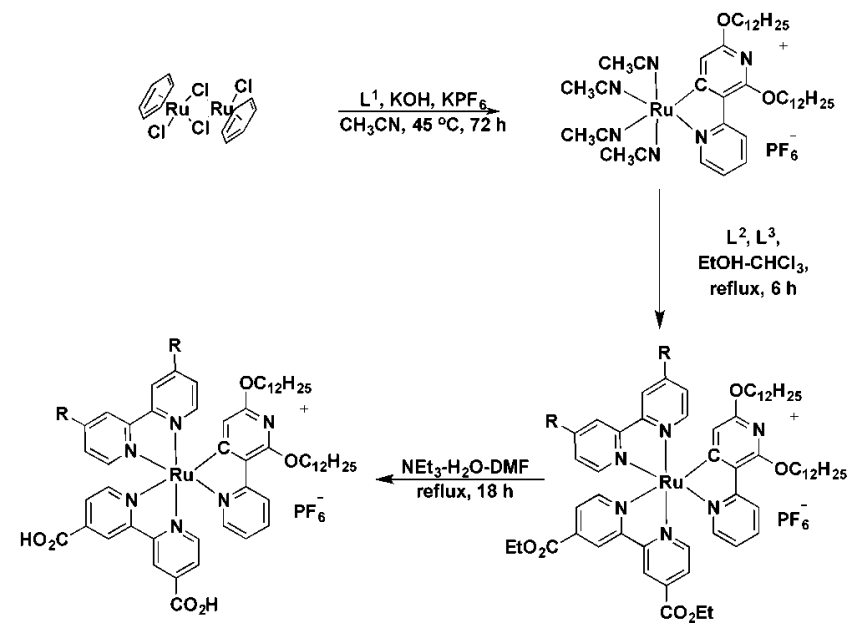

coordinated with the auxiliary and anchoring ligands in a onepot reaction, resulting in three products: two cyclometalated bis-heteroleptic complexes and one tris-heteroleptic complex. ${ }^{23}$ It is worth mentioning that from the two possible isomers, where the cyclometalated ligand is in the trans position to the auxiliary or anchoring ligand pyridines, the former one is usually formed, as was shown from the single-crystal X-ray diffraction structures. ${ }^{23,32}$ Thus, the new ruthenium(II) complexes were separated and hydrolyzed to yield the final dye. All intermediates were characterized by ${ }^{1} \mathrm{H}$ NMR and the 
final complexes by ${ }^{1} \mathrm{H}$ NMR, ${ }^{13} \mathrm{C} 135$ DEPT NMR, and highresolution mass spectrometry. The results are provided in the Supporting Information.

Optical and Electrochemical Properties. Figure 2 shows the absorption spectra of the SA dyes in dichloromethane

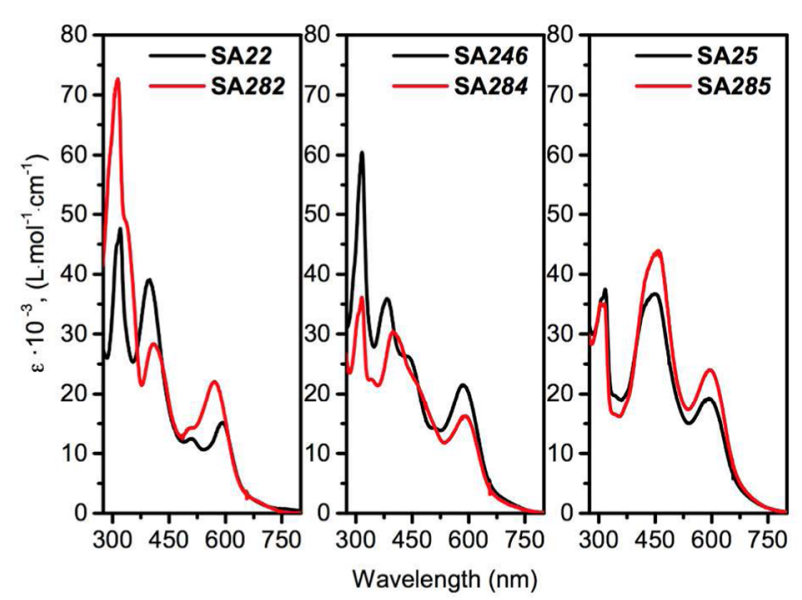

Figure 2. UV-vis absorption spectra of SA22, SA25, SA246, SA282, SA284, and SA285 in DCM solution.

(DCM). All sensitizers have a set of $\pi-\pi^{*}$ transitions in the UV and near-UV regions. In the visible region, all dyes have characteristic metal-to-ligand charge-transfer (MLCT) bands. The extinction coefficient for the MLCT bands around $600 \mathrm{~nm}$ varies from $15 \times 10^{3} \mathrm{M}^{-1} \cdot \mathrm{cm}^{-1}$ (for SA22) to $24 \times 10^{3} \mathrm{M}^{-1}$. $\mathrm{cm}^{-1}$ (for SA285). Except SA22 and SA284, all other dyes have more intense absorption bands than the sensitizer $\mathbf{3 b}$ reported in ref 28, which has hexylthiophene substitution on the auxiliary ligand. Moreover, except SA282, in the presented sensitizers, the low-energy MLCT band is red-shifted by 5-15 nm. SA22 and SA282 have similar shapes of absorption spectra. However, in the case of $\mathbf{S A 2 2}$ with the indenothiophene-substituted auxiliary ligand, the MLCT bands are red-shifted compared to that of SA282 with fluorene moieties on the auxiliary ligands. Despite the substantial MLCT band shift between SA22 and SA282 $(\approx 21 \mathrm{~nm})$, the steeper drop of the MLCT band in long wavelengths in SA22 compared to SA282 results in a similar $E_{0-0}$ value (1.77 eV; Table 1). SA246 and SA284 with thienothiophene and bithiophene moieties, respectively, also have shapes of absorption spectra similar with that of SA284, having more red-shifted bands in the near-UV region. SA25 and SA285 exhibit similar absorption spectra because of the same cyclopentadithiophenes. However, SA285, with longer alkyl chains on the cyclopentadithiophene moieties, has a higher extinction coefficient for the MLCT band than SA25.

Figure S3 presents the cyclic voltammograms of the SA dyes. From the intersection of normalized absorbance and emittance (Figure $S 1$ ), $E_{0-0}$ was calculated, and the excited-state oxidation potentials were calculated by subtracting $E_{0-0}$ from the groundstate oxidation potentials. Table 1 and Figure 3 summarize the obtained optical and electrochemical data.

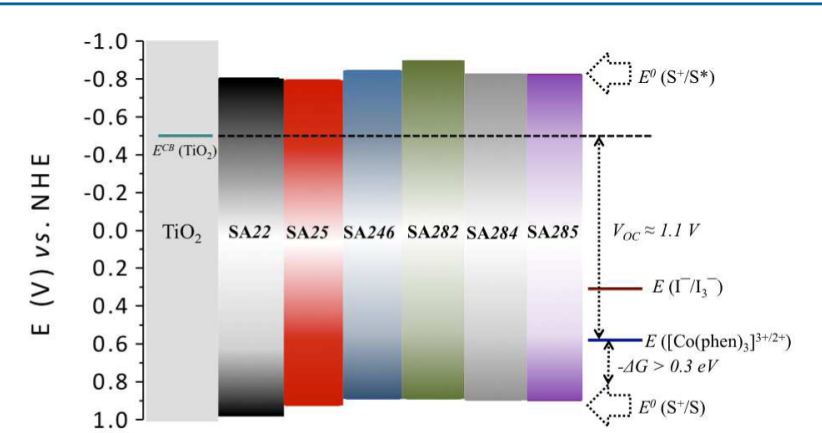

Figure 3. Energy diagram representing sensitizers' ground-state (GS) and excited-state (ES) oxidation potentials and redox couples' Nernst potentials with respect to the conduction band of $\mathrm{TiO}_{2}$. The sensitizer's GS oxidation potential was determined from cyclic voltammetry measurements, and the ES oxidation potential was obtained by subtracting $E_{0-0}$ from the GS oxidation potential. Redox couple Nernst potentials are shown considering concentrations in a $\mathrm{Z} 90^{40}$ iodine-based electrolyte and in an optimized cobalt-based electrolyte.

All dyes have oxidation potentials between 0.88 and $0.92 \mathrm{~V}$, which are higher than the $\mathrm{Co}$ (phen $)_{3}^{3+/ 2+}$ standard oxidation potential $(0.62 \mathrm{~V})$ by at least $260 \mathrm{mV}$. This difference should create enough driving force for efficient dye regeneration. SA22 and SA282 have similar $E_{0-0}$ values, which ideally should lead to identical MLCT band positions. The ground-state oxidation potential of SA285 $(0.89 \mathrm{~V})$ is surprisingly lower than that of SA25 $(0.92 \mathrm{~V})$ by $30 \mathrm{mV}$. Because of the same $E_{0-0}$ values, the difference is maintained in the excited state. However, the error in cyclic voltammetry measurements up to $0.1 \mathrm{~V}$ has to be considered. All presented sensitizers have the excited-state oxidation potentials in the range of -0.79 to $-0.89 \mathrm{~V}$ versus

Table 1. Photophysical and Electrochemical Properties of Dyes

\begin{tabular}{|c|c|c|c|c|c|c|}
\hline dye & $\lambda_{\mathrm{abs} / \max } \mathrm{nm}\left(\varepsilon \times 10^{a}{ }^{-3} \mathrm{~L} \cdot \mathrm{mol}^{-1} \cdot \mathrm{cm}^{-1}\right.$ & $\begin{array}{c}E^{0}\left(\mathrm{~S}^{+} / \mathrm{S}\right), \mathrm{V}(\mathrm{vs} \\
\mathrm{NHE})^{b}\end{array}$ & 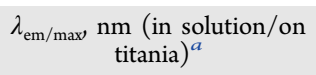 & $\tau_{1 / 2{ }^{c}}$ & $\begin{array}{l}E_{0-0}, \mathrm{eV} \text { (in solution/on } \\
\text { titania) }\end{array}$ & $\begin{array}{c}E^{0}\left(\mathrm{~S}^{+} / \mathrm{S}^{*}\right), \mathrm{V}(\mathrm{vs} \\
\mathrm{NHE})^{e}\end{array}$ \\
\hline SA22 & 592 (15.2), $511(12.5), 399$ (39.2) & 0.97 & $771 / 776$ & 46 & $1.77 / 1.77$ & -0.80 \\
\hline SA25 & $593(19.3), 448(36.7)$ & 0.92 & $808 / 811$ & & $1.71 / 1.71$ & -0.79 \\
\hline SA246 & 585 (21.5), 431sh (26.4), $382(36)$ & 0.88 & $798 / 814$ & 38 & $1.72 / 1.71$ & -0.84 \\
\hline SA282 & $571(22), 508 \mathrm{sh}(14.2), 411(28.2)$ & 0.88 & $775 / 798$ & 48 & $1.77 / 1.74$ & -0.89 \\
\hline SA284 & $592(16.3), 398(30.4)$ & 0.89 & $803 / 810$ & 44 & $1.71 / 1.70$ & -0.82 \\
\hline SA285 & 595 (24.1), $456(44)$ & 0.89 & $804 / 822$ & 82 & $1.71 / 1.67$ & -0.82 \\
\hline $3 \mathbf{b}^{32}$ & 580 (19.6), 507 (14.1), 418 (23.4) & 0.86 & $789 /-$ & & $1.76 /-$ & -0.90 \\
\hline
\end{tabular}

${ }^{a}$ Absorption and emission spectra were measured in DCM at room temperature. ${ }^{b}$ Oxidation potentials were determined from cyclic voltammetry in $0.1 \mathrm{M} \mathrm{NBu}_{4} \mathrm{PF}_{6}$ in $\mathrm{DCM}$. The working electrode was glassy carbon, the counter and reference electrodes were platinum wires and ferrocene ( $\mathrm{Fc}$ ) was used as an internal standard. To calculate the potentials versus NHE, $0.7 \mathrm{~V}$ was used as the $\mathrm{Fc}$ oxidation potential. ${ }^{c}$ Excited-state lifetimes in a DCM solution were determined from fluorescence time-correlated single-photon-counting measurements. ${ }^{d} E_{0-0}$ was determined from the intersection of normalized absorption and emission spectra. ${ }^{e}$ Excited-state dye oxidation potentials were calculated by subtracting $E_{0-0} / q$ (where $q$ is a charge and is equal to one electron) from the ground-state oxidation potential. 
NHE, which should guarantee an efficient charge injection into the titania conduction band.

One of the desired properties of a DSC sensitizer is its capability of sustaining numerous oxidation-reduction cycles under long-term operation, e.g., turnover numbers reaching 100 million for an outdoor lifetime of 20 years. Isothiocyanate ligands employed often for ruthenium(II) complexes cannot survive because of ligand exchange by electrolyte components such as tert-butylpyridine. ${ }^{41}$

In this regard, cyclometalated ruthenium(II) complexes were introduced as being potentially more stable, by ruling out the possibility of ligand exchange. However, on the basis of cyclic voltammetry measurements, our ruthenium(II) complexes are quasi-reversible because the obtained shifts between the peaks of the oxidative and reductive waves are usually around 120 $\mathrm{mV}^{5,23,28,35-39}$

To understand the origin of the electrochemical irreversibility in cyclometalated ruthenium dyes, we conducted spectroelectrochemical measurements in solution and in the complete device without a redox pair. We focused on the bands above $300 \mathrm{~nm}$. Typical examples are represented in Figure S4. In solution (Figure S4A), none of these six complexes showed complete reversibility of both the $\pi-\pi^{*}$ and MLCT bands. Among them, SA22 and SA246 showed the best reversibility. However, these results should not be discouraging because dye features on titania may strongly change. In complete devices, SA22, SA282, and SA284 showed reversible behavior only for the $\pi-\pi^{*}$ transitions. Conversely, SA25, SA246, and SA285 have reversible MLCT bands in a device, but the $\pi-\pi^{*}$ transitions around $450 \mathrm{~nm}$ become extinct, indicating that the coordination core is more stable than the polyaromatic substituents (Figure S4C).

Computational Analysis. In Figure S5, the optimized geometries of studied SA dyes are shown. All of them have the typical geometry of ruthenium tris-bipyridine complexes. These optimizations were carried out for the isomers, which have a cyclometalated pyridine ring in the position trans to one of the anchoring carboxypyridine rings. It is worth noting that calculated molecular volumes meet expectations, and SA246 and SA284 with the least number of substituents have the lowest molecular volumes (Table S1).

Among the entire series of SA dyes, the lowest unoccupied molecular orbitals (LUMOs) have very close energies (Table S2) and are localized on the anchoring ligand, as can be observed from the isodensity plots in Figures S6 and S7. However, the HOMOs present variation in the energies mainly because of localization on the different substituents. In particular, SA25 and SA285 exhibit the highest HOMO energies with a consequent decrease of the HOMO-LUMO energy gap. As expected, the HOMOs not only are localized on the metal $t_{2 g}$ orbitals but also are partially delocalized through the auxiliary ligand, the degree of which depends on the different substituents. In SA25 and SA285, both cyclopentadithiophene moieties on the auxiliary ligands contribute to a major fraction of the HOMO. In SA22, SA246, and SA284, only one donating moiety on the auxiliary ligands, which is in the trans position to the anchoring carboxypyridine ring, owns a fraction of the HOMO. Fluorene moieties on the auxiliary ligand in SA282 do not possess any substantial fraction of the HOMO (Figure S7). These observations imply that, among all of these substituents on the auxiliary ligands, cyclopentadithiophene and fluorene own the strongest and weakest donating power, considering that dihedral angles between the substituents and pyridine rings of the auxiliary ligand may also play a role (Table S1). Because the dihedral angles between the indenothiophene or fluorene moieties and pyridine planes are close values according to the density functional theory (DFT) calculations ( 36 and $38^{\circ}$, respectively; Table S1), the red-shifted spectrum of SA22 (or SA285) with respect to SA282 is more reasonably due to the higher donating power of indenothiophene than fluorene. Although the shapes of theoretical spectra do not perfectly follow the experimental results (Figure S8), the absorption maxima and the main calculated transitions (Table S4) are in perfect agreement with the experimental optical data.

TAS. To evaluate the influence of different substituents on the lifetimes of the photooxidized dyes in the environment of cobalt-based electrolytes, we performed TAS measurements on unbiased devices. Measurements were carried out on two different types of cells containing (a) redox-inactive pure acetonitrile and (b) a cobalt-based electrolyte. Dye molecules were excited with a low-intensity pulsed laser at $510 \mathrm{~nm}$ to ensure an average of less than one injected electron per nanoparticle, i.e., typically $40 \mu \mathrm{J} \cdot \mathrm{cm}^{-2}$. The probe was monitored at $900 \mathrm{~nm}$, following the oxidized dye signature, and transient absorbance decay was fitted with a monoexponential function (Figure S9).

We find a regeneration yield of above $94 \%$ for all dyes, except SA282 and SA285. A low regeneration yield for SA282 and SA285 is reasonable considering the steric hindrance of their hexyl chains, which drastically affects the regeneration lifetime. We also observe that, for most of the dyes, regeneration does not seem complete and the dynamics reach a plateau, suggesting remaining oxidized species in the system. It is worth noting that, to estimate the regeneration efficiency, we consider that electron recombination with photooxidized dye and dye regeneration with the electrolyte rates follow first-order dynamics on the reductant concentration $\eta_{\text {reg }}=\tau_{\text {rec }} /\left(\tau_{\text {rec }}+\tau_{\text {reg }}\right)$, where $\tau_{\text {rec }}$ is the electron-oxidized dye recombination lifetime and $\tau_{\text {reg }}$ the oxidized dye regeneration lifetime in the presence of an electrolyte; Table S6]. This procedure may not exactly represent the situation in a device under full sun illumination considering the following facts: (a) dye regeneration is not necessarily a first-order reaction ${ }^{42}$ and (b) the electron density in $\mathrm{TiO}_{2}$ created by the laser pulse is not comparable to the electron density in the performing device at maximum power point. ${ }^{43,44}$ The second fact may bring an overestimated lifetime of photooxidized dyes in the devices with a redox-inactive electrolyte at a low-light regime. Although not exactly picturing devices in working conditions, we use these data as an approximation of the charge-transfer dynamics. ${ }^{45}$

EIS. The $V_{\mathrm{OC}}$ trends of the devices with various dyes can be predicted by EIS analysis on complete devices in the dark. The Nyquist plots were fitted according to the transmission-line model developed by Bisquert et al., and the main parameters were extracted. ${ }^{46,47}$ They comprise the charge-transfer resistance, $R_{\mathrm{ct}}$ representing the charge recombination resistance for the electron in the $\mathrm{TiO}_{2}$ conduction band with the oxidized form of the redox couple, the chemical capacitance, $C_{\mu}$, representing the density of states (DOS) accessible to electrons in the $\mathrm{TiO}_{2}$ nanocrystals, and the transport resistance, $R_{\text {trans }}$, representing the resistance for the transport of the electrons through the mesoporous $\mathrm{TiO}_{2}$ network. Using the obtained charge recombination $\left(R_{\mathrm{ct}}\right)$ and transport $\left(R_{\text {trans }}\right)$ resistances along with the chemical capacitance $\left(C_{\text {chem }}\right)$ of the titania, one 

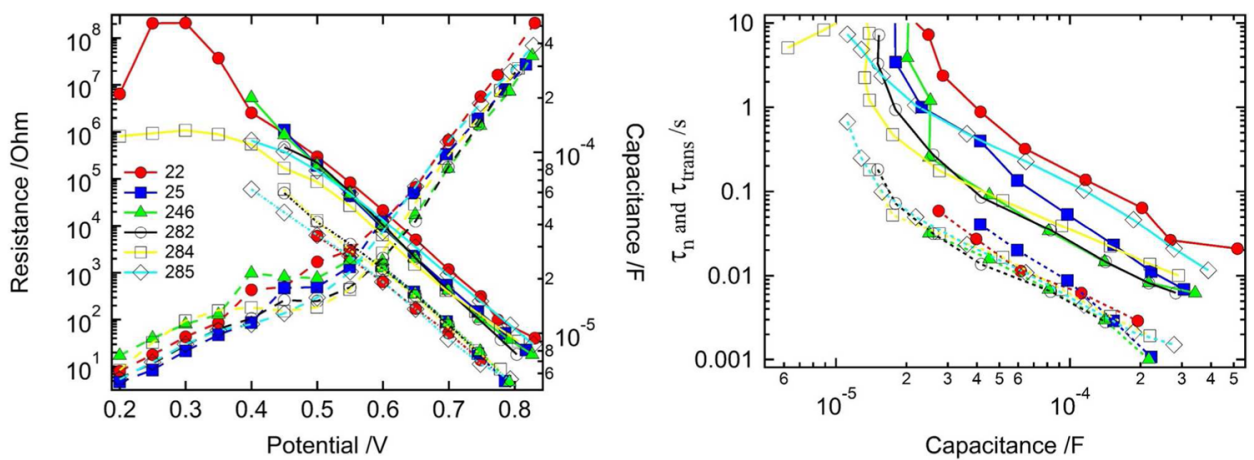

Figure 4. Key parameters extracted from EIS analyses of the cobalt-based devices: recombination resistance (solid lines); transport resistance (dotted lines) and capacitance (dashed lines) over potential (left); electron recombination lifetime (solid lines) and transport lifetime (dotted lines) as a function of the capacitance (right). In all figures, lines with red, blue, green, black, yellow, and cyan colors refer to the devices with SA22, SA25, SA246, SA282, SA284, and SA285, respectively.

can calculate the electron lifetime $\left(\tau_{\mathrm{n}}\right)$ and transport time $\left(\tau_{\text {trans }}\right)$ as $\tau_{\mathrm{n}}=R_{\mathrm{ct}} C_{\text {chem }}$ and $\tau_{\text {trans }}=R_{\text {trans }} C_{\text {chem }}$

The main parameters from the EIS fitting of cobalt-based devices are shown in Figures 4 and S10. The cobalt-based devices showed pronounced changes in the conduction-band edge position. It is interesting to note that the highest chemical capacitance, and so the lowest conduction band, and the highest electron lifetimes were observed for SA22, followed by SA285, while the lowest values of the electron lifetime were obtained for SA246 and SA282.

The differences in $V_{\mathrm{OC}}$ due to the conduction-band shift and electron lifetime were estimated in reference to the values obtained with SA22 and are presented in Table 2.

Table 2. Comparison of the $V_{\mathrm{OC}}$ Differences Estimated from EIS Analyses and Obtained from the $J-V$ Measurements for the Cobalt-Based Electrolytes

\begin{tabular}{lcccr}
\multicolumn{1}{c}{ dye } & $\begin{array}{c}\Delta E^{\mathrm{CB} a}, \\
\mathrm{mV}\end{array}$ & $\begin{array}{c}\tau_{\mathrm{n}}{ }^{b} \mathrm{~s}(\Delta V \text { due to a } \\
\text { change in } \tau_{\mathrm{n}} \text { with } \\
\text { respect to SA22, mV })\end{array}$ & $\begin{array}{c}\text { estimated } \Delta V_{\mathrm{OC}}= \\
\Delta E^{\mathrm{CB}}+\Delta V(\text { due } \\
\left.\text { to } \Delta \tau_{\mathrm{n}}\right)^{c}\end{array}$ & $\begin{array}{r}\Delta V_{\mathrm{OC},}{ }^{d} \\
\mathrm{mV}\end{array}$ \\
SA22 & 0 & 0.180 & & 0 \\
SA25 & 24 & $0.052(-32)$ & -8 & -17 \\
SA246 & 40 & $0.024(-52)$ & -12 & 18 \\
SA282 & 22 & $0.025(-51)$ & -27 & -33 \\
SA284 & 23 & $0.035(-43)$ & -20 & -33 \\
SA285 & 15 & $0.120(-11)$ & 4 & -20
\end{tabular}

${ }^{a}$ The shift in the conduction-band edge was estimated from EIS analyses. ${ }^{b}$ The change in the voltage due to a change in the electron lifetime was calculated using the diode equation. ${ }^{{ }^{c}}$ Total estimated change in $V_{\mathrm{OC}}$ due to the conduction-band edge difference and electron lifetime. ${ }^{d}$ The difference in $V_{\mathrm{OC}}$ obtained from the $J-V$ measurements. All values are brought in reference to the case with SA22. Positive values indicate the rise in $V_{\mathrm{OC}}$.

Photovoltaic Performance. Finally, to evaluate the influence of ligands on the photovoltaic performance, we put the complete devices with the cobalt-based electrolytes under photovoltaic characterization and present the results in Table 3. The iodine-based devices were also tested, and the results are shown in Figure S11B and Table S7. In the case of the DSCs with cobalt-based electrolytes, both $J_{\mathrm{SC}}$ and $V_{\mathrm{OC}}$ vary significantly between 9 and $14 \mathrm{~mA} \cdot \mathrm{cm}^{-2}$ and 794 and 845 $\mathrm{mV}$ with the following trends: for $J_{\mathrm{SC}}, \mathrm{SA282}<\mathrm{SA25}<\mathrm{SA284}$ $<$ SA285 < SA22 < SA246; for $V_{\mathrm{OC}}$, SA282 = SA284 < SA285 $<$ SA25 < SA22 < SA246 (Figure 5 and Table 3). The sensitizer called SA246 showed the best IPCE, which is in agreement with the measured $J_{\mathrm{SC}}$ value. Inconsistencies are found in both $J_{\mathrm{SC}}$ and $V_{\mathrm{OC}}$, especially with SA246, which has relatively blue-shifted absorption spectrum and the lowest electron lifetime. An unexpected trend in the $V_{\mathrm{OC}}$ and $J_{\mathrm{SC}}$ values indicating some more vital parameters is controlling the photovoltaic performance.

Despite the indistinctive molar extinction coefficient and moderate absorption range with SA246, the high $J_{\text {SC }}$ over other sensitizers is a baffling feature. To explain the highest $J_{\mathrm{SC}}$ provided by SA246, we analyzed the amount of dye adsorbed on the surface. One way to evaluate the absolute dye loading is the desorption experiment of sensitized titania films (Figure 6). The amount of SA246 adsorbed on titania is drastically higher compared to other dyes. It is worth noting that SA285 also provides high dye loading; however, because of inefficient dye regeneration (vide supra), SA285 fails to yield high PCE. The high dye loading of SA246 increased the absorbance (optical density) of the sensitized titania, which, in turn, boosted $J_{S C}$ more than the other sensitizers with a higher molecular molar extinction coefficient and a wider absorption range. This effect has already been indicated by the IPCE spectra (Figure 5B).

At the same time, it is quite unexpected that the device with SA246 gave the highest $V_{\mathrm{OC}}$ even though it possesses the lowest electron lifetime and therefore the highest recombination. It is known that the long electron lifetime is a necessary but not sufficient condition to lead to high $V_{\mathrm{OC}}$. We have to take the change in $J_{\mathrm{SC}}$ under light into consideration, which has been completely neglected in ESI analyses; e.g., the inversed correlation of the electron lifetime and $V_{\mathrm{OC}}$ in the case of SA22 and SA246 can be explained by the higher $J_{S C}$ in the case of SA246. Higher $J_{S C}$ will induce a higher steady-state electron density in titania in the performing device, which yields an upwardly shifted quasi-Fermi level $E_{F, n}^{*}$ and, hence, $V_{\mathrm{OC}}$. In this case, the rise in $V_{\mathrm{OC}}$ compensates for the loss due to high electron recombination.

\section{CONCLUSION}

Six new cyclometalated tris-heteroleptic ruthenium complexes were synthesized and characterized in the course of ligand engineering compatible with cobalt-based electrolytes in DSCs. The substituents on the auxiliary ligand were the focus of this study. Various substituents result in different photophysical properties and different performances in the DSCs. With the cobalt-based devices, the record efficiency to date featuring 
Table 3. Photovoltaic Performance of Iodine- and Cobalt-Based DSCs with SA Dyes

\begin{tabular}{|c|c|c|c|c|c|c|}
\hline $\mathrm{dye}^{a}$ & electrolyte & $J_{\mathrm{SC}}, \mathrm{mA} / \mathrm{cm}^{2}$ & $V_{\mathrm{OC}}, \mathrm{mV}$ & FF, $\%$ & $\operatorname{PCE}(10 \%)$ & $\operatorname{PCE}(100 \%)$ \\
\hline SA22 & ${ }^{b}\left[\mathrm{Co}(\text { phen })_{3}\right]^{3+/ 2+}$ & 12.25 & 827 & 75.5 & 8.4 & 7.9 \\
\hline SA25 & ${ }^{b}\left[\mathrm{Co}(\text { phen })_{3}\right]^{3+/ 2+}$ & 10.68 & 810 & 77.9 & 7.4 & 6.9 \\
\hline SA246 & ${ }^{b}\left[\mathrm{Co}(\text { phen })_{3}\right]^{3+/ 2+}$ & 14.55 & 845 & 74.7 & 9.4 & 9.4 \\
\hline SA282 & ${ }^{b}\left[\mathrm{Co}(\text { phen })_{3}\right]^{3+/ 2+}$ & 9.89 & 794 & 78.5 & 6.7 & 6.3 \\
\hline SA284 & ${ }^{b}\left[\mathrm{Co}(\text { phen })_{3}\right]^{3+/ 2+}$ & 11.28 & 794 & 76.9 & 7.2 & 7.0 \\
\hline SA285 & ${ }^{c}\left[\mathrm{Co}(\text { phen })_{3}\right]^{3+/ 2+}$ & 11.85 & 807 & 73.6 & 6.1 & 7.2 \\
\hline
\end{tabular}

${ }^{a}$ All cells were measured under AM 1.5 simulated solar light irradiation with a power of $100 \mathrm{~mW} \cdot \mathrm{cm}^{-2}$ at room temperature; ${ }^{b}$ Cobalt-based electrolyte: $0.25 \mathrm{M}\left[\mathrm{Co}^{\mathrm{II}}(\mathrm{phen})_{3}\right](\mathrm{TFSI})_{2}, 0.05 \mathrm{M}\left[\mathrm{Co}^{\mathrm{III}}(\mathrm{phen})_{3}\right](\mathrm{TFSI})_{3}, 0.25 \mathrm{M}$ 4-(5-nonyl)pyridine, and $0.1 \mathrm{M}$ LiTFSI; ${ }^{c} \mathrm{Cobalt}-\mathrm{based}$ electrolyte: $0.25 \mathrm{M}\left[\mathrm{Co}^{\mathrm{II}}(\mathrm{phen})_{3}\right](\mathrm{TFSI})_{2}, 0.05 \mathrm{M}\left[\mathrm{Co}^{\mathrm{III}}(\mathrm{phen})_{3}\right](\mathrm{TFSI})_{3}, 0.5 \mathrm{M}$ 4-(5-nonyl)pyridine, and $0.1 \mathrm{M}$ LiTFSI.
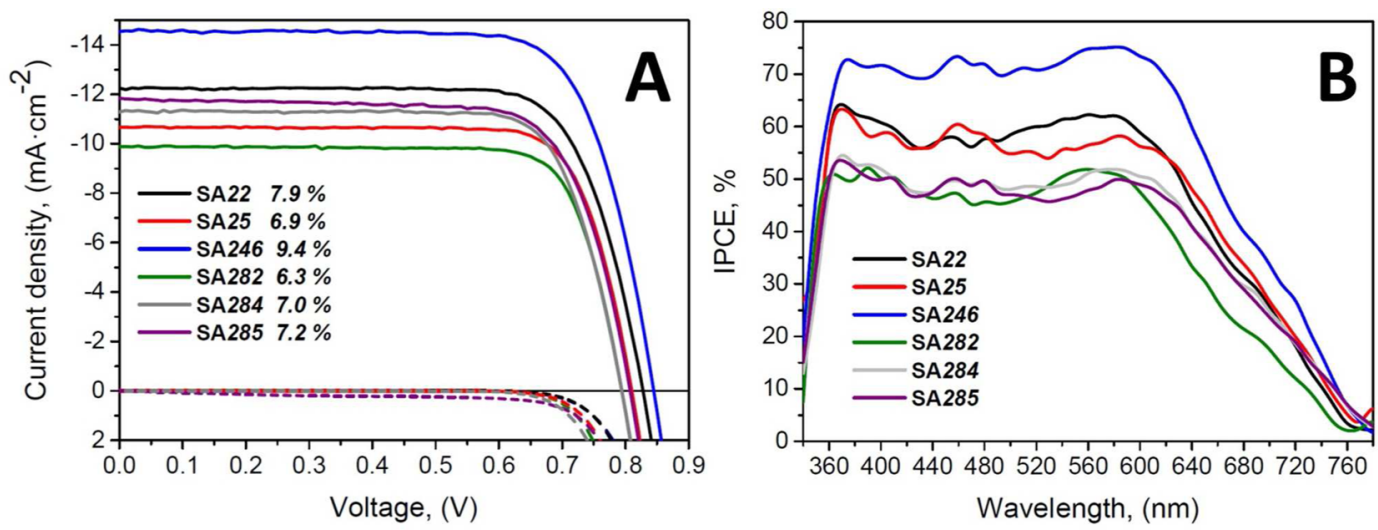

Figure 5. (A) $J-V$ curves and (B) IPCE curves for DSCs based on cobalt electrolytes and cyclometalated ruthenium dyes SA22, SA25, SA246, SA282, SA284, and SA285.

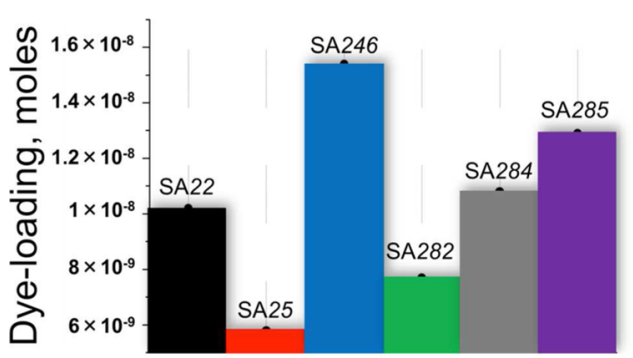

Figure 6. Dye-loading values obtained by the desorption of SA dyes from the titania films.

ruthenium-based dyes was obtained for SA246 as $9.4 \%$. The highest efficiency is explained by the higher dye loading, a factor that is normally neglected by the designers. The high absolute dye loading increases the optical density, which can lead to a higher photocurrent and voltage. This effect can even overwhelm the influence of the recombination rate. Provided in this work, different analyses indicate the complexity of the processes taking place and underline the compromise between various parameters to be considered from the sensitizer-design viewpoint. For the cobalt-based devices, the sensitizer molecule should have small enough size to maintain (i) efficient dye regeneration and (ii) high dye loading and, at the same time, (iii) a bulky periphery to keep the redox mediator away from the semiconductor surface. These results could be very instructive for further dye engineering to reach even higher PCEs.

\section{ASSOCIATED CONTENT}

\section{Supporting Information}

The Supporting Information is available free of charge on the ACS Publications website at DOI: 10.1021/acs.inorgchem.6b00842.

Synthetic procedures and characterization of all products, descriptive preparation of solar cells, photoluminescence spectra and excited-state decay for the final complexes, cyclic voltammograms for the final complexes, and DFT-time-dependent DFT calculation parameters and results (PDF)

\section{AUTHOR INFORMATION}

\section{Corresponding Author}

*E-mail: mdkhaja.nazeeruddin@epfl.ch.

\section{Notes}

The authors declare no competing financial interest.

\section{ACKNOWLEDGMENTS}

S.A. thanks the European Community's Seventh Framework Programme under Grants 308997 ("NanoMatCell”) and 309194 (“GLOBASOL”).

\section{REFERENCES}

(1) Lewis, N. S.; Nocera, D. G. Proc. Natl. Acad. Sci. U. S. A. 2006, 103, 15729-15735.

(2) O’Regan, B.; Grätzel, M. Nature 1991, 353, 737-740.

(3) Nazeeruddin, M. K.; Kay, A.; Rodicio, I.; Humphry-Baker, R.; Müller, E.; Liska, P.; Vlachopoulos, N.; Grätzel, M. J. Am. Chem. Soc. 1993, 115, 6382-6390.

(4) Mishra, A.; Fischer, M. K. R.; Bäuerle, P. Angew. Chem., Int. Ed. 2009, 48, 2474-2499. 
(5) Nazeeruddin, M. K.; Péchy, P.; Renouard, T.; Zakeeruddin, S. M.; Humphry-Baker, R.; Comte, P.; Liska, P.; Cevey, L.; Costa, E.; Shklover, V.; Spiccia, L.; Deacon, G. B.; Bignozzi, C. A.; Grätzel, M. J. Am. Chem. Soc. 2001, 123, 1613-1624.

(6) Yu, Q.; Wang, Y.; Yi, Z.; Zu, N.; Zhang, J.; Zhang, M.; Wang, P. ACS Nano 2010, 4, 6032-6038.

(7) Chen, C. Y.; Wang, M.; Li, J. Y.; Pootrakulchote, N.; Alibabaei, L.; Ngoc-le, C.; Decoppet, J. D.; Tsai, J. H.; Grätzel, C.; Wu, C. G.; Zakeeruddin, S. M.; Grätzel, M. ACS Nano 2009, 3, 3103-3109.

(8) Ardo, S.; Meyer, G. J. Chem. Soc. Rev. 2009, 38, 115-164.

(9) Boschloo, G.; Hagfeldt, A. Acc. Chem. Res. 2009, 42, 1819-1826.

(10) Peter, L. M. Phys. Chem. Chem. Phys. 2007, 9, 2630-2642.

(11) Snaith, H. J. Adv. Funct. Mater. 2010, 20, 13-19.

(12) Zhang, Z.; Chen, P.; Murakami, T. N.; Zakeeruddin, S. M.; Grätzel, M. Adv. Funct. Mater. 2008, 18, 341-346.

(13) Daeneke, T.; Kwon, T. H.; Holmes, A. B.; Duffy, N. W.; Bach, U.; Spiccia, L. Nat. Chem. 2011, 3, 213-217.

(14) Feldt, S. M.; Gibson, E. A.; Gabrielsson, E.; Sun, L.; Boschloo, G.; Hagfeldt, A. J. Am. Chem. Soc. 2010, 132, 16714-16724.

(15) Feldt, S. M.; Wang, G.; Boschloo, G.; Hagfeldt, A. J. Phys. Chem. C 2011, 115, 21500-21507.

(16) Giribabu, L.; Bolligarla, R.; Panigrahi, M. Chem. Rec. 2015, 15, 760-788.

(17) Colombo, A.; Dragonetti, C.; Magni, M.; Roberto, D.; Demartin, F.; Caramori, S.; Bignozzi, C. A. ACS Appl. Mater. Interfaces 2014, 6, 13945-13955.

(18) Magni, M.; Giannuzi, R.; Colombo, A.; Cipolla, M. P.; Dragonetti, C.; caramori, S.; Carli, S.; Grisorio, R.; Suranna, G. P.; Bignozzi, C. A.; Roberto, D.; Manca, M. Inorg. Chem. 2016, 55, 52455253, DOI: 10.1021/acs.inorgchem.6b00204.

(19) Nusbaumer, H.; Moser, J.-E.; Zakeeruddin, S. M.; Nazeeruddin, M. K.; Grätzel, M. J. Phys. Chem. B 2001, 105, 10461-10464.

(20) Sapp, S. A.; Elliott, C. M.; Contado, C.; Caramori, S.; Bignozzi, C. A. J. Am. Chem. Soc. 2002, 124, 11215-11222.

(21) Klahr, B. M.; Hamann, T. W. J. Phys. Chem. C 2009, 113, $14040-14045$.

(22) Liu, Y.; Jennings, J. R.; Huang, Y.; Wang, Q.; Zakeeruddin, S. M.; Grätzel, M. J. Phys. Chem. C 2011, 115, 18847-18855.

(23) Bomben, P. G.; Gordon, T. J.; Schott, E.; Berlinguette, C. P. Angew. Chem., Int. Ed. 2011, 50, 10682-10685.

(24) Mosconi, E.; Yum, J. H.; Kessler, F.; Gómez García, C. J.; Zuccaccia, C.; Cinti, A.; Nazeeruddin, M. K.; Grätzel, M.; De Angelis, F. J. Am. Chem. Soc. 2012, 134, 19438-19453.

(25) Omata, K.; Kuwahara, S.; Katayama, K.; Qing, S.; Toyoda, T.; Lee, K.-M.; Wu, C.-G. Phys. Chem. Chem. Phys. 2015, 17, 1017010175 .

(26) Tsao, H. N.; Yi, C.; Moehl, T.; Yum, J.-H. H.; Zakeeruddin, S. M.; Nazeeruddin, M. K.; Grätzel, M. ChemSusChem 2011, 4, 591-594.

(27) Yella, A.; Lee, H. W.; Tsao, H. N.; Yi, C.; Chandiran, A. K.; Nazeeruddin, M. K.; Diau, E. W. G.; Yeh, C. Y.; Zakeeruddin, S. M.; Grätzel, M. Science 2011, 334, 629-634.

(28) Mathew, S.; Yella, A.; Gao, P.; Humphry-Baker, R.; Curchod, B. F.; Ashari-Astani, N.; Tavernelli, I.; Rothlisberger, U.; Nazeeruddin, M. K.; Grätzel, M. Nat. Chem. 2014, 6, 242-247.

(29) Yella, A.; Mai, C.-L. L.; Zakeeruddin, S. M.; Chang, S.-N. N.; Hsieh, C.-H. H.; Yeh, C.-Y. Y.; Grätzel, M. Angew. Chem., Int. Ed. 2014, 53, 2973-2977.

(30) Yum, J.-H. H.; Baranoff, E.; Kessler, F.; Moehl, T.; Ahmad, S.; Bessho, T.; Marchioro, A.; Ghadiri, E.; Moser, J.-E. E.; Yi, C.; Nazeeruddin, M. K.; Grätzel, M. Nat. Commun. 2012, 3, 631.

(31) Kakiage, k.; Aoyama, Y.; Yano, T.; Oya, K.; Fujisawa, J.-I.; Hanaya, M. Chem. Commun. 2015, 51, 15894-15897.

(32) Polander, L. E.; Yella, A.; Curchod, B. F.; Ashari-Astani, N.; Teuscher, J.; Scopelliti, R.; Gao, P.; Mathew, S.; Moser, J.-E. E.; Tavernelli, I.; Rothlisberger, U.; Grätzel, M.; Nazeeruddin, M. K.; Frey, J. Angew. Chem., Int. Ed. 2013, 52, 8731-8735.

(33) Wu, K. L.; Clifford, J. N.; Wang, S. W.; Aswani, Y.; Palomares, E.; Lobello, M. G.; Mosconi, E.; De Angelis, F.; Ku, W. P.; Chi, Y.; Nazeeruddin, M. K.; Grätzel, M. ChemSusChem 2014, 7, 2930-2938.
(34) Wu, K. L.; Hu, Y.; Chao, C. T.; Yang, Y. W.; Hsiao, T. Y.; Robertson, N.; Chi, Y. J. Mater. Chem. A 2014, 2, 19556-19565.

(35) Bessho, T.; Yoneda, E.; Yum, J.-H.; Guglielmi, M.; Tavernelli, I.; Imai, H.; Rothlisberger, U.; Nazeeruddin, M. K.; Grätzel, M. J. Am. Chem. Soc. 2009, 131, 5930-5934.

(36) Bomben, P. G.; Koivisto, B. D.; Berlinguette, C. P. Inorg. Chem. 2010, 49, 4960-4971.

(37) Bomben, P. G.; Borau-Garcia, J.; Berlinguette, C. P. Chem. Commun. 2012, 48, 5599-5601.

(38) Martiniani, S.; Anderson, A. Y.; Law, C.; O’Regan, B.; Barolo, C. Chem. Commun. 2012, 48, 2406-2408.

(39) Anderson, A.; Barnes, P.; Durrant, J.; O’Regan, B. J. Phys. Chem. C 2011, 115, 2439-2447.

(40) Barnes, P.; Anderson, A.; Durrant, J.; O’Regan, B. Phys. Chem. Chem. Phys. 2011, 13 (13), 5798-5816.

(41) Jennings, J. R.; Liu, Y.; Wang, Q. J. Phys. Chem. C 2011, 115, 15109-15120.

(42) Martiniani, S.; Anderson, A. Y.; Law, C.; O’Regan, B.; Barolo, C. Chem. Commun. 2012, 48, 2406-2408.

(43) Anderson, A.; Barnes, P.; Durrant, J.; O’Regan, B. J. Phys. Chem. C 2011, 115, 2439-2447.

(44) Jennings, J. R.; Liu, Y.; Wang, Q. J. Phys. Chem. C 2011, 115, 15109-15120.

(45) Li, F.; Jennings, J. R.; Wang, Q. ACS Nano 2013, 7, 8233-8242.

(46) Fabregat-Santiago, F.; Bisquert, J.; Garcia-Belmonte, G.; Boschloo, G.; Hagfeldt, A. Sol. Energy Mater. Sol. Cells 2005, 87, 117-131.

(47) Fabregat-Santiago, F.; Garcia-Belmonte, G.; Mora-Sero, I.; Bisquert, J. Phys. Chem. Chem. Phys. 2011, 13, 9083-9118. 


\section{Supporting Information}

\section{Ligand Engineering for the Efficient Dye-Sensitized Solar Cells with Ruthenium Sensitizers and Cobalt Electrolytes}

Sadig Aghazada ${ }^{1}$, Peng Gao ${ }^{1}$, Aswani Yella ${ }^{2}$, Gabriele Marotta ${ }^{3,5}$, Thomas Moehl², Joël Teuscher $^{4}$, Jacques-E. Moser ${ }^{4}$, Filippo De Angelis ${ }^{3}$, Michael Grätzel ${ }^{2}$, Mohammad Khaja Nazeeruddin ${ }^{1}$.

${ }^{1}$ Group for Molecular Engineering of Functional Materials, École Polytechnique Fédérale de Lausanne (EPFL), CH-1950, Sion, Switzerland.

${ }^{2}$ Laboratory of Photonics and Interfaces (LPI), École Polytechnique Fédérale de Lausanne (EPFL), CH-1015, Lausanne, Switzerland.

${ }^{3}$ Computational Laboratory for Hybrid Organic Photovoltaics (CLHYO), Istituto CNR di Scienze e Tecnologie Molecolari, via Elce di Sotto 8, I-06123, Perugia, Italy.

${ }^{4}$ Photochemical Dynamics Group, École Polytechnique Fédérale de Lausanne (EPFL), CH1015, Lausanne, Switzerland.

${ }^{5}$ Dipartimento di Chimica, Biologia e Biotecnologie, Università di Perugia, via Elce di Sotto 8, I06123 Perugia, Italy. 


\section{Table of Contents}

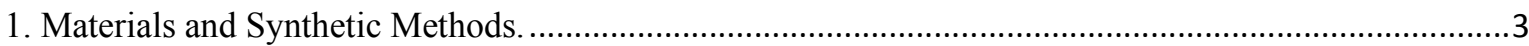

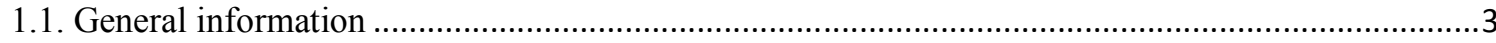

1.2. Synthetic scheme

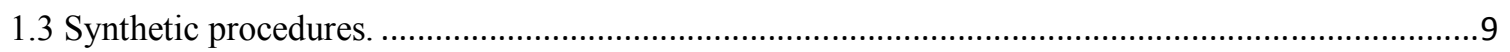

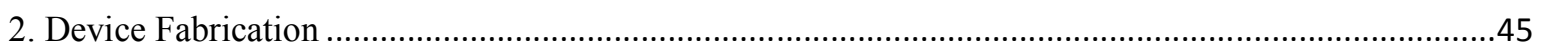

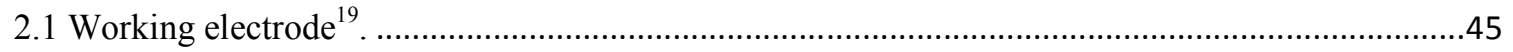

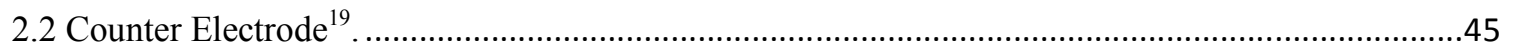

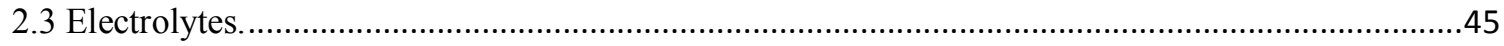

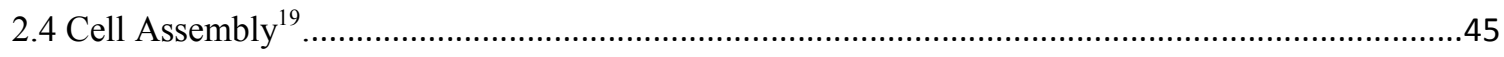

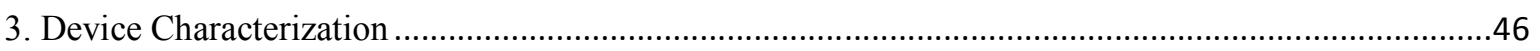

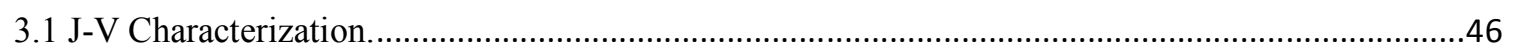

4. Optical and Electrochemical Characterization of sensitizers. .........................................................46

4.1 Electronic absorption and emission spectra ………...................................................................

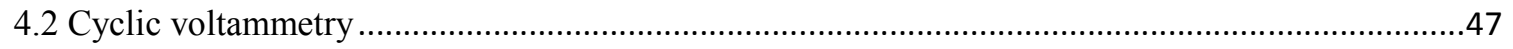

4.3 Time-Correlated Single Photon Counting ............................................................................. 47

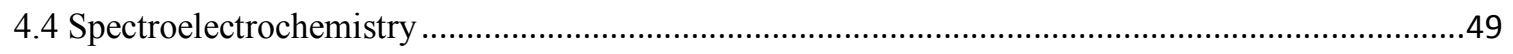

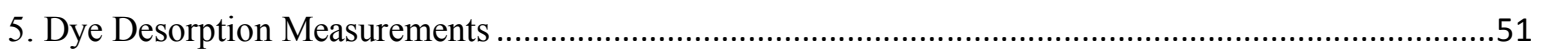

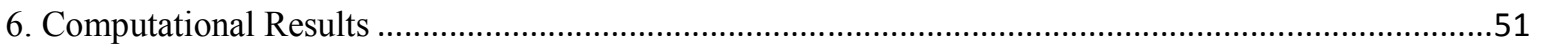

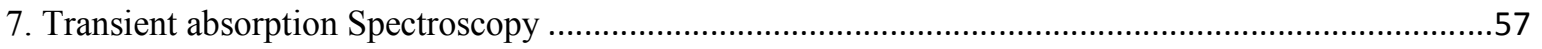

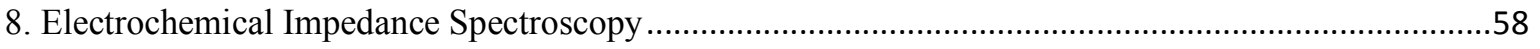

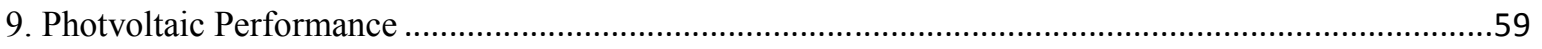

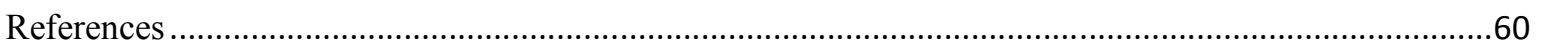




\section{Materials and Synthetic Methods.}

\subsection{General information}

All starting materials were reagent grade and used without further purification. Anhydrous solvents were purchased from Acros Organics (THF, Toluene, acetonitrile, dichloromethane) and used as received. 2',6'-didodecyloxy-2,3'-bipyridine ${ }^{1}$ and 2-bromo-9,9-dihexyl-9H-fluorene ${ }^{2}$ was synthesized according to the reported procedure. Standard flash column chromatography method was used either with silica (Merck: silica gel 60, 230-400 mesh ASTM) or basic alumina (Acros: aluminium oxide, basic Brockmann I, 50-200 $\mu \mathrm{m}, 60 \mathrm{~A}$ ). Analytical thin-layer chromatography was performed on aluminium-backed sheets pre-coated with silica 60 F254 adsorbent ( $0.25 \mathrm{~mm}$ thick; Merck, Germany). All water and air sensitive reactions were performed in oven dried flasks and standard Schlenk techniques were used. NMR spectra have been recorded at ambient temperature in deuterated solvents on a Bruker AVANCE $400 \mathrm{MHz}$ or AVANCE III $400 \mathrm{MHz}$ instruments. Electrospray ionization (ESI) and matrix-assisted laser desorption ionization (MALDI) mass spectrometry data were collected at Swiss Federal Institute of Technology (EPFL). 


\subsection{Synthetic scheme.}

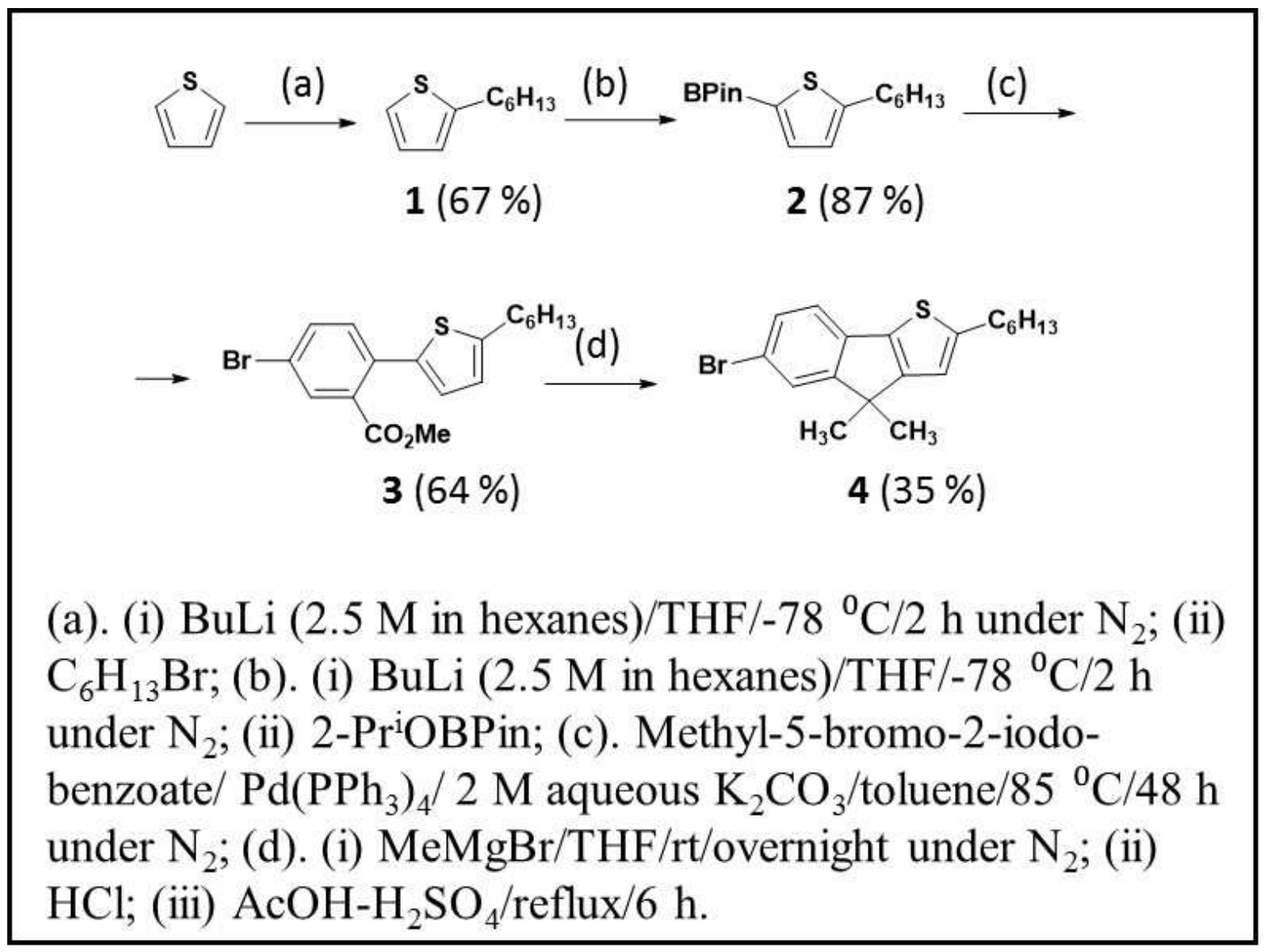



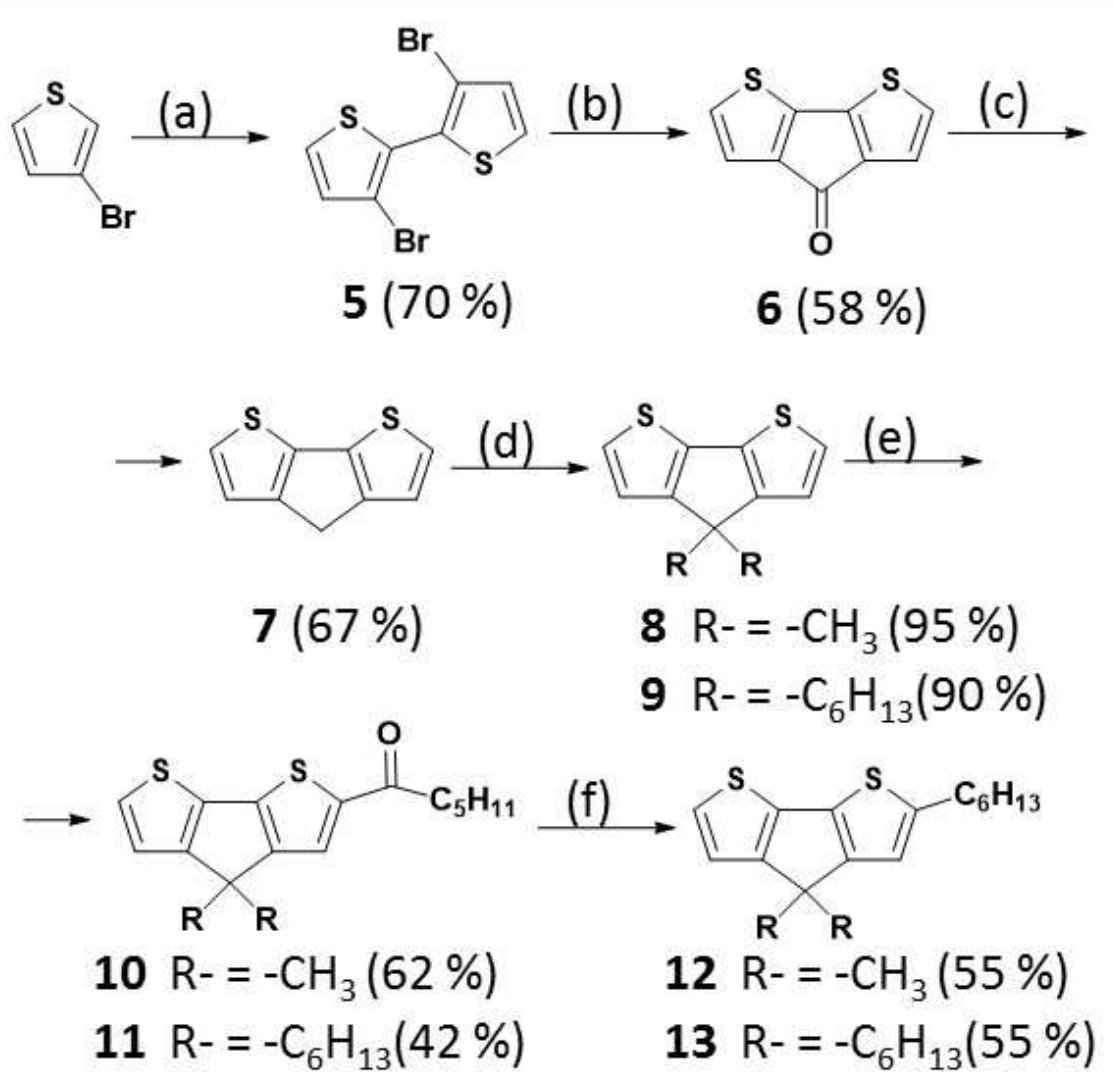

(a). (i) $\mathrm{LDA} / \mathrm{THF} /-78{ }^{\circ} \mathrm{C} / 1 \mathrm{~h}$ under $\mathrm{N}_{2}$; (ii) $\mathrm{CuCl}_{2} / 1 \mathrm{~h}$ at -78 ${ }^{0} \mathrm{C} / 5 \mathrm{~h}$ at rt under $\mathrm{N}_{2}$; (iii) $\mathrm{NH}_{4} \mathrm{Cl}_{\mathrm{aq}}$ (b). (i) $\mathrm{BuLi}(2.5 \mathrm{M}$ in hexanes) $/ \mathrm{THF} /-78{ }^{\circ} \mathrm{C} / 0.5$ h under $\mathrm{N}_{2}$; (ii) $\mathrm{N}, \mathrm{N}-$ dimethylcarbamoyl chloride $/-78{ }^{0} \mathrm{C}$ to $0{ }^{\circ} \mathrm{C} / 3$ h under $\mathrm{N}_{2}$; (iii) $\mathrm{NH}_{4} \mathrm{Cl}_{\mathrm{aq}} ;$; (c). $\mathrm{KOH}, \mathrm{N}_{2} \mathrm{H}_{4}{ }^{*} \mathrm{H}_{2} \mathrm{O} / 200^{\circ} \mathrm{C} /$ ethylene glycole under $\mathrm{N}_{2}$; (d). $\mathrm{KOH}, \mathrm{KI}, \mathrm{MeI}$ (or hexyl bromide)/rt/12 h under $\mathrm{N}_{2}$; (e). (i) Hexanoyl chloride/DCM/rt under $\mathrm{N}_{2}$; (ii). $\mathrm{AlCl}_{3} / 0$ ${ }^{0} \mathrm{C}$ to $\mathrm{rt} / 24$ h under $\mathrm{N}_{2}$; (iii) $\mathrm{HCl}$; (f). (i) $\mathrm{LiAlH}_{4}-\mathrm{AlCl}_{3} / \mathrm{Et}_{2} \mathrm{O} / 0$ ${ }^{0} \mathrm{C}$ to $\mathrm{rt} / 4 \mathrm{~h}$ under $\mathrm{N}_{2}$; (ii) $\mathrm{H}_{2} \mathrm{O}$ 

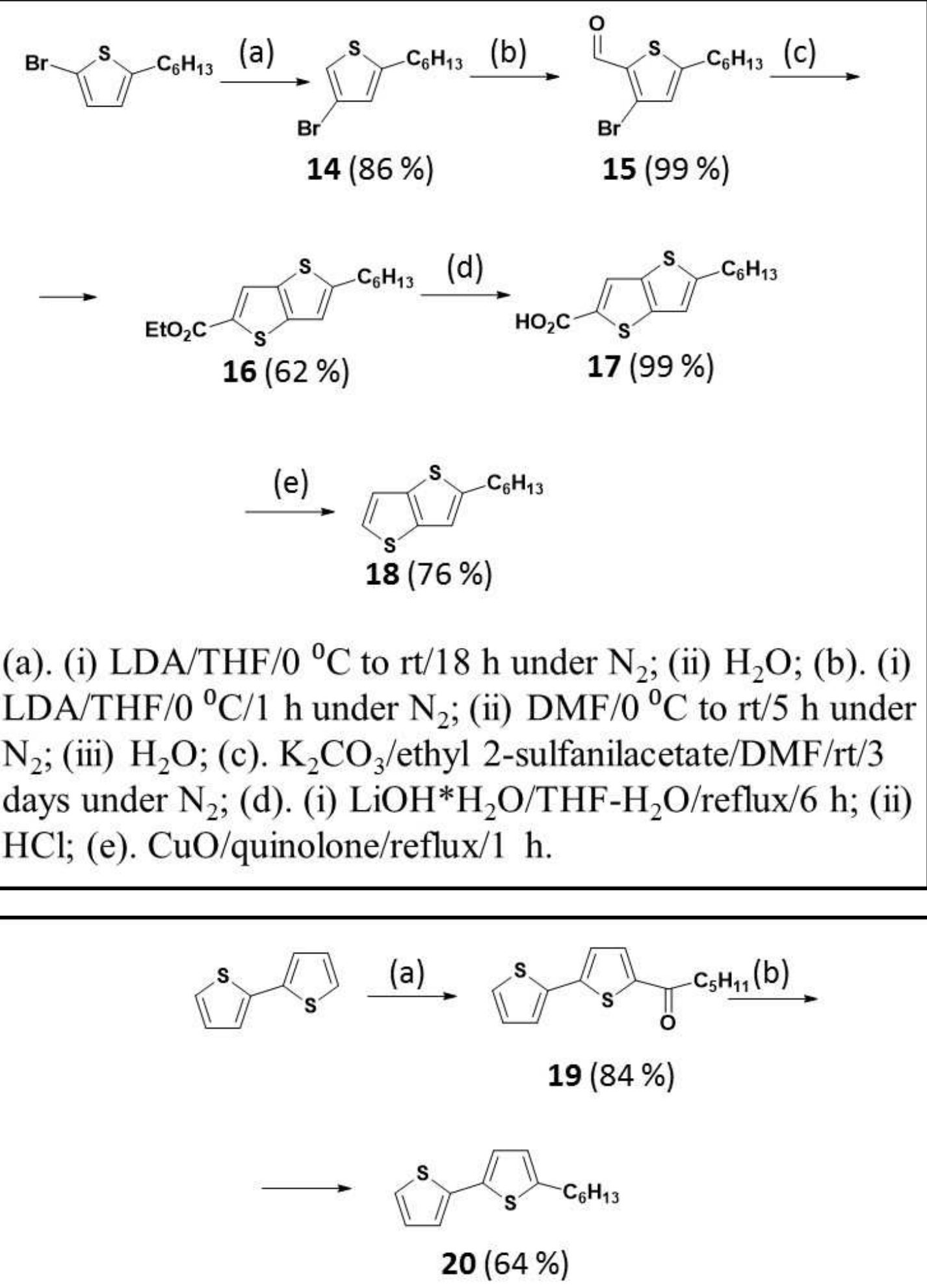

(a). (i) Hexanoyl chloride/DCM/rt/under $\mathrm{N}_{2}$; (ii). $\mathrm{AlCl}_{3} / 0{ }^{0} \mathrm{C}$ to $\mathrm{rt} / 24 \mathrm{~h}$; (iii) $\mathrm{HCl}$; (b). (i) $\mathrm{LiAlH}_{4}-\mathrm{AlCl}_{3} / \mathrm{Et}_{2} \mathrm{O} / 0{ }^{0} \mathrm{C}$ to $\mathrm{rt} / 4 \mathrm{~h}$ under $\mathrm{N}_{2}$; (ii) $\mathrm{H}_{2} \mathrm{O}$ 


$$
\text { (b3\%) }
$$

(a). NBS/acetone/reflux/3 h; (b).

Bromohexane.KOBu$/ \mathrm{DMF} / 60{ }^{0} \mathrm{C} / 6 \mathrm{~h}$ under $\mathrm{N}_{2}$.

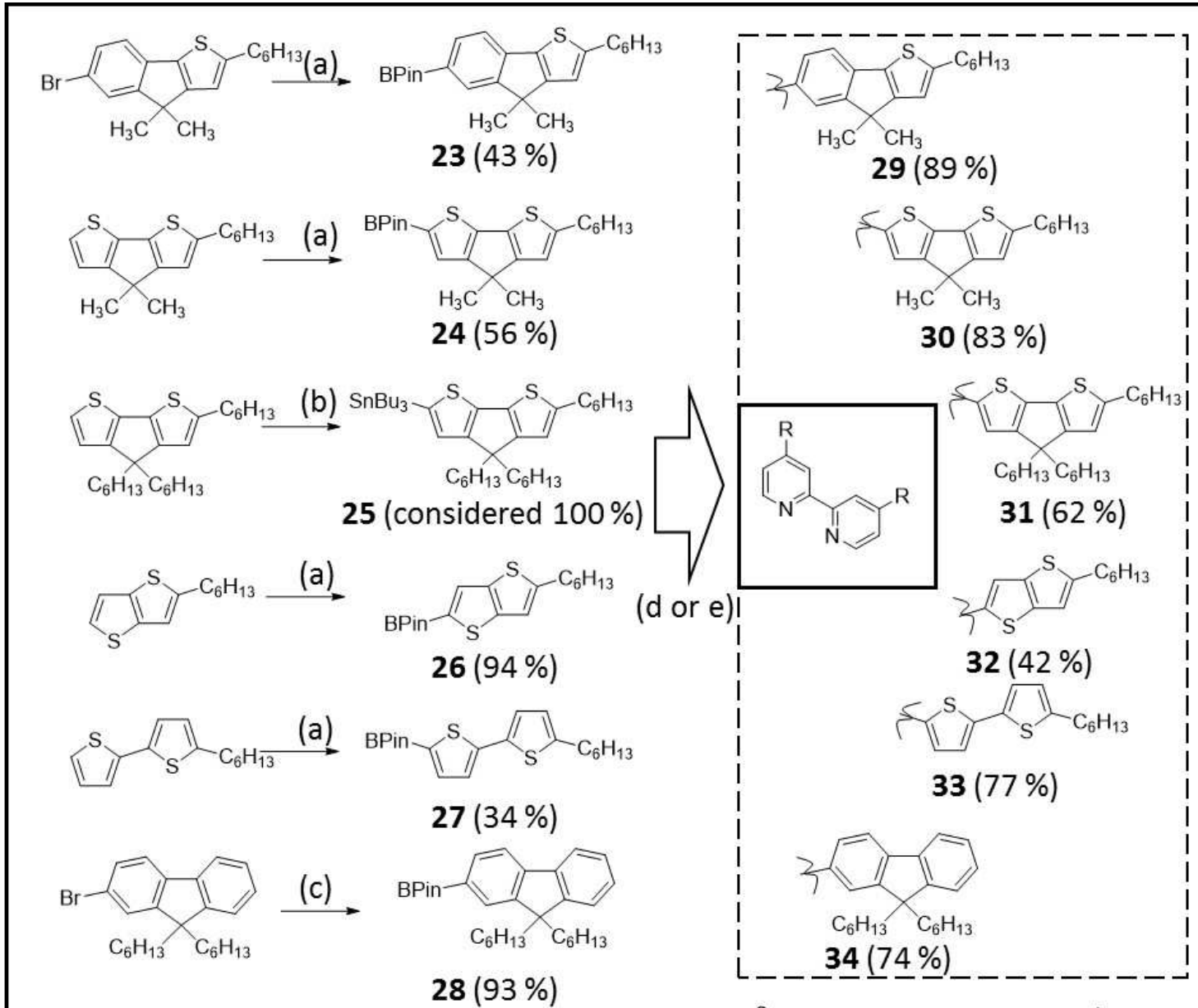

(a). (i) $\mathrm{BuLi}\left(2.5 \mathrm{M}\right.$ in hexanes) $/ \mathrm{THF} /-41$ or $-78{ }^{\circ} \mathrm{C} / 2 \mathrm{~h}$ under $\mathrm{N}_{2}$; (ii) $\mathrm{Pr}{ }^{\mathrm{i} O B P}$ in under $\mathrm{N}_{2}$; (iii) $\mathrm{H}_{2} \mathrm{O}$ (b). (i) $\mathrm{BuLi}\left(2.5 \mathrm{M}\right.$ in hexanes) $/ \mathrm{THF} /-78{ }^{\circ} \mathrm{C} / 2 \mathrm{~h}$ under $\mathrm{N}_{2}$; (ii) $\mathrm{Bu}_{3} \mathrm{SnCl}$ under $\mathrm{N}_{2}$; (iii) $\mathrm{H}_{2} \mathrm{O}$; (c). $\mathrm{B}_{2} \mathrm{Pin}_{2}, \mathrm{KOAc}$, $\mathrm{Pd}$ (dppf) $\mathrm{Cl}_{2} /$ dioxane $/ 80{ }^{\circ} \mathrm{C} / 6 \mathrm{~h}$ under $\mathrm{N}_{2}$; (d). 4,4'-dibromo-2,2'-bopyridine, $\mathrm{Pd}\left(\mathrm{PPh}_{3}\right)_{4}, \mathrm{~K}_{2} \mathrm{CO}_{3} /$ toluene-water $(4: 1) / 80{ }^{\circ} \mathrm{C} / 24$ h under $\mathrm{N}_{2}$; (e). 4,4'dibromo-2,2'-bopyridine, $\mathrm{Pd}\left(\mathrm{PPh}_{3}\right)_{4} / \mathrm{DMF} / 80{ }^{\circ} \mathrm{C} / 12 \mathrm{~h}$ under $\mathrm{N}_{2}$; 


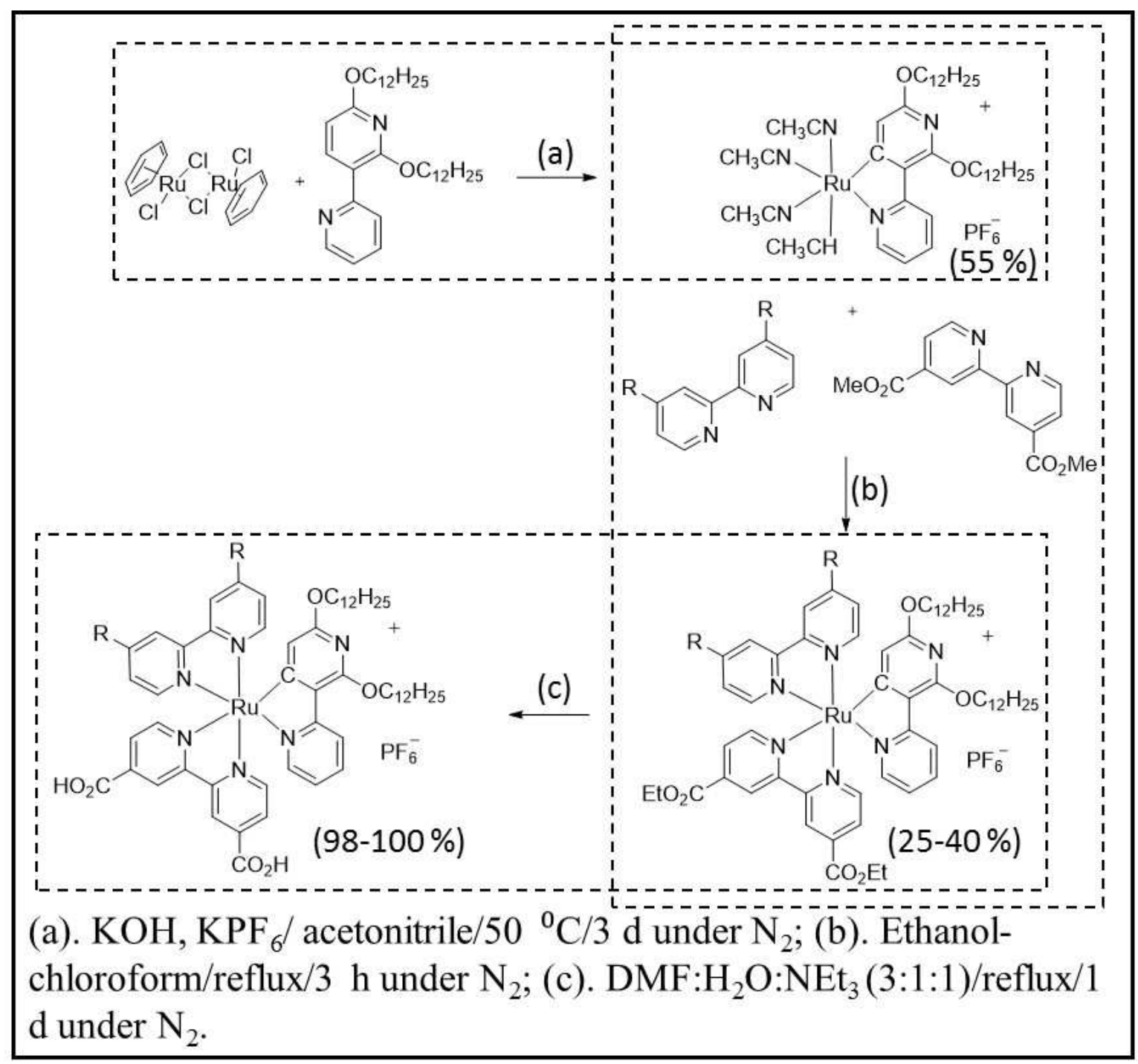




\subsection{Synthetic procedures.}

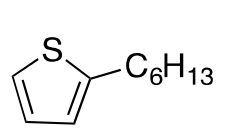

2-hexylthiophene (1) ${ }^{3.4} \mathrm{n}$-BuLi (2.5 M in hexane) $(60 \mathrm{~mL}, 0.15 \mathrm{~mol})$ was added dropwise to the solution of thiophene $(15 \mathrm{~g}, 0.18 \mathrm{~mol})$ in $150 \mathrm{~mL}$ of THF at -78

${ }^{\mathrm{O}} \mathrm{C}$. After $45 \mathrm{~min}$. upon addition, $27 \mathrm{~g}$ of 1-bromohexane $(0.16 \mathrm{~mol})$ were added to the solution. The reaction mixture was then warmed to room temperature, stirred for another 3 $\mathrm{h}$ and poured into water. The mixture was extracted with ether, dried over $\mathrm{MgSO}_{4}$, and the solvent evaporated. The compound was purified by flash chromatography (silica/hexane). $20 \mathrm{~g}$ of pure product (colorless liquid) were obtained (Yield: 67\%). ${ }^{1} \mathrm{H} \mathrm{NMR}$ (400 MHz, Chloroformd) $\delta 7.18(\mathrm{~d}, \mathrm{~J}=4 \mathrm{~Hz}, 1 \mathrm{H}), 7.00(\mathrm{t}, \mathrm{J}=4 \mathrm{~Hz}, 1 \mathrm{H}), 6.87(\mathrm{~d}, 4 \mathrm{~Hz}, 1 \mathrm{H}), 2.91(\mathrm{t}, 2 \mathrm{H}), 1.8(\mathrm{p}, 2 \mathrm{H}), 1.5-$ $1.3(\mathrm{~m}, 4 \mathrm{H}), 1(\mathrm{t}, 3 \mathrm{H})$

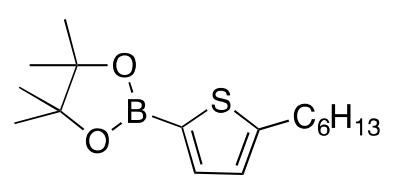

2-(5-hexylthiophen-2-yl)-4,4,5,5-tetramethyl-1,3,2-dioxaborolane (2) ${ }^{5,6}$ A solution of $1(10 \mathrm{~g}, 60 \mathrm{mmol})$ in dry THF $(30 \mathrm{ml})$ was cooled to $-78{ }^{\circ} \mathrm{C}$ under nitrogen and treated with a $2.5 \mathrm{M}$ solution of $\mathrm{BuLi}$ in hexane $(27.5 \mathrm{~mL}, 68 \mathrm{mmol})$. The temperature was slowly raised to room temperature and the reaction mixture was stirred for 25-30 minutes. The reaction mixture was cooled again to $-78{ }^{\circ} \mathrm{C}$ and the 2-isopropoxy-4,4,5,5-tetramethyl-1,3,2-dioxaborolane (14 $\mathrm{mL}, 68 \mathrm{mmol}$ ) was added. Then the mixture was stirred for $3 \mathrm{~h}$ and the solvent was removed in the vacuo. The crude product was dissolved in $\mathrm{CH}_{2} \mathrm{Cl}_{2}$ and the solution was washed with water. Dried solution was purified by flash chromatography ( silica/ $\mathrm{CH}_{2} \mathrm{Cl}_{2}$ ). Then the solvent was evaporate to give $15.2 \mathrm{~g}$ of yellow oil (Yield: $87 \%$ ). ${ }^{1} \mathrm{H} \mathrm{NMR}(400 \mathrm{MHz}$, Chloroform-d) $\delta 7.5$ (s, $1 \mathrm{H}), 6.9(\mathrm{~s}, 1 \mathrm{H}), 2.8(\mathrm{t}, 2 \mathrm{H}), 1.7(\mathrm{p}, 2 \mathrm{H}), 1.4-1.2(\mathrm{~m}, 4 \mathrm{H}), 0.9(\mathrm{t}, 3 \mathrm{H})$

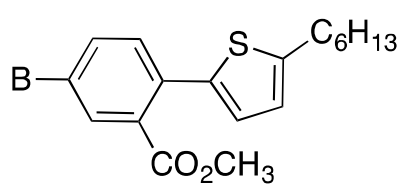

Methyl 2-(5-hexylthiophen-2-yl)-5-bromobenzoate (3) ${ }^{7} 2$ (4.32 g, $14.7 \mathrm{mmol}$ ) methyl-5-bromo-2-iodobenzoate (5 g, $14.7 \mathrm{mmol})$, $\mathrm{K}_{2} \mathrm{CO}_{3}(5.52 \mathrm{~g})$ were dissolved in toluene $(80 \mathrm{ml})$ and water $(20 \mathrm{ml})$. Then the mixture was degassed with nitrogen for 30 minutes. After, 5 mol \% of $\mathrm{Pd}\left(\mathrm{PPh}_{3}\right)_{4}(0,44 \mathrm{mmol})$ was added to the mixture. Then the mixture was stirred at $85{ }^{\circ} \mathrm{C}$ for $48 \mathrm{~h}$. The reaction progress was checked by TLC (hexane : dichloromethane 3:1). After evaporating the solvent under reduced pressure, water was added and the product was extracted by dichloromethane. Organic layer was dried on magnesium sulfate and the pure product was obtained by column chromatography on silica gel (hexane: dichloromethane 3:1). After drying under high vacuum $3.6 \mathrm{~g}$ (64\%) of yellow viscous product was obtained. ${ }^{1} \mathrm{H} N \mathrm{NR}$ (400 MHz, Chloroform-d) $\delta 7.82(\mathrm{~d}, \mathrm{~J}=2,2 \mathrm{~Hz}, 1 \mathrm{H}), 7.58(\mathrm{dd}, \mathrm{J}=8.3,2.2 \mathrm{~Hz}, 1 \mathrm{H}), 7.34$ (d, J=8,3 $\mathrm{Hz}, 1 \mathrm{H}), 6.85$ (d, J=3.5 Hz, 1H), 6.73 (d, J=3.5 Hz, 1H), 2.83 (t, J=7.6 Hz, 2H), 1,71 (p, J=7.5 $\mathrm{Hz}, 2 \mathrm{H}), 1.43-1.27(\mathrm{~m}, 6 \mathrm{H}), 0.92(\mathrm{t}, 3 \mathrm{H})$.

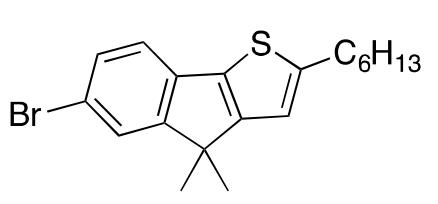

2-hexyl-6-bromo-4,4-dimethyl-4H-indeno[1,2-b]thiophene

To the two-necked flask dropping-glass funnel was attached and system was dried by heating gun and degassed with nitrogen. 3 (4.6 $\mathrm{g}, 12 \mathrm{mmol})$ was dissolved in $60 \mathrm{ml}$ of dry THF and $\mathrm{MeMgBr}(1 \mathrm{M}$ in THF, $36 \mathrm{~mL}, 36 \mathrm{mmol}$ ) was dropwise added over 2 hours and reaction mixture was stirred under nitrogen overnight. After reaction mixture was neutralized with $1 \mathrm{M} \mathrm{HCl}$ and organic products were extracted by dichloromethane, dried over magnesium sulfate and evaporated to the minimal amount. Tertiary alcohol without further purification was used for the next step. 4:1 mixture of glacial acetic acid and $98 \%$ sulfuric acid $(80 \mathrm{~mL})$ was added; mixture was purged 
with nitrogen and refluxed for 6 hours. After reaction mixture was cooled down, neutralized with $25 \mathrm{M}$ solution of ammonia, extracted with dichloromethane, dried over magnesium sulfate and purified by flash chromatography (hexane:DCM 4:1). (1.54 g, yield: 35\%). ${ }^{1} \mathrm{H} \mathrm{NMR}(400 \mathrm{MHz}$, Chloroform-d) $\delta 7.45(\mathrm{~d}, \mathrm{~J}=1.8 \mathrm{~Hz}, 1 \mathrm{H}), 7.37$ (dd, J=8.0, $1.8 \mathrm{~Hz}, 1 \mathrm{H}), 7.19(\mathrm{~d}, \mathrm{~J}=8.0 \mathrm{~Hz}, 1 \mathrm{H})$, $6.72(\mathrm{~s}, 1 \mathrm{H}), 2.85$ (t, J=7.2 Hz, $2 \mathrm{H}, 1.72$ (p, J=7.4 Hz, $2 \mathrm{H}), 1.43$ (s, $6 \mathrm{H}), 1.40-1.23$ (m, 6H), $0.91(\mathrm{t}, 1 \mathrm{H})$

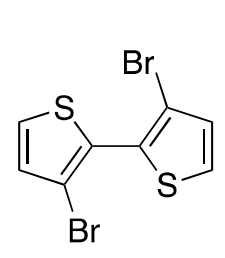

3,3'-dibromo-2,2'-bithiophene (5) ${ }^{8}$ To the stirring solution of 3bromothiophene $(20.0 \mathrm{~g} ; 122.8 \mathrm{mmol})$ in $150 \mathrm{~mL}$ dry tetrahydrofuran at $-78{ }^{\circ} \mathrm{C}$ freshly prepared lithium diisopropylamide (LDA) $(122.8 \mathrm{mmol})$ in $80 \mathrm{~mL}$ of dry THF was added dropwise. After stirring at $-78{ }^{\circ} \mathrm{C}$ for one hour copper (II) chloride $\left(\mathrm{CuCl}_{2}\right)$ (33 $\left.\mathrm{g} ; 245 \mathrm{mmol}\right)$ was added portionwise and the reaction mixture was stirred another one hour at $-78^{\circ} \mathrm{C}$ and 5 hours at room temperature. Afterwards, the reaction mixture was quenched with saturated aqueous solution of ammonia chloride. Organic phase was extracted with dichloromethane, washed with water and dried over magnesium sulfate and evaporated to minimal amount. Pure product was obtained by column chromatography on silica gel (hexane:DCM 95:5) applying a dry loading of the product in hexane due to bad solubility in hexane. (13.9 g, yield: $70 \%$ ). ${ }^{1} H$ NMR (400 MHz, Chloroform-d) $\delta 7.40(\mathrm{~d}, \mathrm{~J}=5.4$ $\mathrm{Hz}, 2 \mathrm{H}), 7.09$ (d, J=5.4 Hz, 2H).

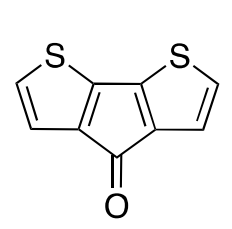

4H-cyclopenta[1, $2-\boldsymbol{b}: 5,4-b^{\prime}$ '] dithiophene-4-one (6) ${ }^{9}$ In the oven dried Schlenk tube 5 ( $4 \mathrm{~g}, 12.3 \mathrm{mmol})$ was dissolved in $30 \mathrm{~mL}$ of dry THF under nitrogen. Solution was cooled down to $-78^{\circ} \mathrm{C}$ and $\mathrm{n}$-BuLi $(2.5 \mathrm{M}$ in hexanes, $10 \mathrm{~mL}, 25$ $\mathrm{mmol}$ ) was dropwise, while colorless mixture became yellowish. Then mixture was stirred for 30 minutes and N,N-dimethylcarbamoyl chloride (1.335 g, 12.4 mmol) in $10 \mathrm{~mL}$ of dry THF was added, mixture warmed up to $0{ }^{\circ} \mathrm{C}$ and stirred for $3 \mathrm{~h}$. Then aqueous solution of ammonia chloride $(4.84 \mathrm{~g}$, in $36 \mathrm{~mL}$ of water) was added, during what the mixture becomes intensely red. Organic phase was extracted with hexanes, washed with water and dried over magnesium sulfate. Pure product was obtained after column chromatography on silica gel (hexane:EtOAc 30:1). (1.38 g, yield: $58 \%$ ). ${ }^{1} \mathrm{H} \mathrm{NMR}(400 \mathrm{MHz}$, Chloroform-d) $\delta 7.05$ (d, J=4.9 Hz, 2H), 7.01 (d, J=4.9 Hz, 2H).

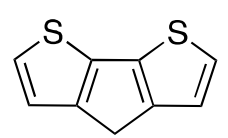

4H-cyclopenta[1,2-b:5,4-b']dithiophene (7) Finely ground potassium hydroxide $(0.5 \mathrm{~g})$ was added to the suspension of $6(0.5 \mathrm{~g}, 2,6 \mathrm{mmol})$ in $100 \mathrm{~mL}$ of ethylene glycol under nitrogen. Then the mixture was heated to $200{ }^{\circ} \mathrm{C}$ and hydrazine hydrate $(1 \mathrm{~mL})$ was added dropwise. The mixture was stirred at $200{ }^{\circ} \mathrm{C} 2$ hours more, cooled to room temperature and quenched with water $(10 \mathrm{~mL})$. The organic phase was extracted with diethyl ether, washed with water, brine and dried over magnesium sulfate. After evaporating the solvent a crude product was purified by flash chromatography over silica and hexane as an eluent. (279 mg, yield: 67\%). ${ }^{1} H$ NMR (400 MHz, Chloroform-d) $\delta 7.19$ (d, J=4.9 $\mathrm{Hz}, 1 \mathrm{H}), 7.10$ (d, J=4.9 Hz, 1H), 3.65 (s, 2H).

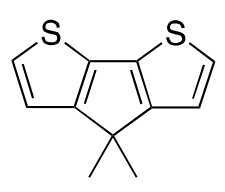

4,4-dimethyl-4H-cyclopenta[1,2-b:5,4-b']dithiophene (8) ${ }^{7}$ To the mixture of 7 (450 mg, 2,5 mmol), KI (35 mg), MeI (850 mg, $6 \mathrm{mmol})$ in DMSO (15 mL), at 0 ${ }^{\circ} \mathrm{C}$ potassium hydroxide $(500 \mathrm{mg})$ in one portion was added. Then the reaction mixture was stirred at room temperature for 12 hours. After, organic phase was extracted with ether and washed several times with water to decrease the amount of DMSO in 
organic phase. Then, combined organic phases were dried over $\mathrm{MgSO}_{4}$, evaporated and purified by flash chromatography on silica gel with hexane as an eluent.: $(0.49 \mathrm{~g}$, yield: $95 \%) .{ }^{1} H \mathrm{HMR}$ (400 MHz, Chloroform-d) $\delta 7.16(\mathrm{~d}, \mathrm{~J}=4.9 \mathrm{~Hz}, 1 \mathrm{H}), 7.00(\mathrm{~d}, \mathrm{~J}=4.9 \mathrm{~Hz}, 1 \mathrm{H}), 1.46(\mathrm{~s}, 6 \mathrm{H})$.

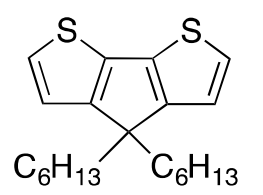

4,4-dihexyl-4H-cyclopenta[1,2-b:5,4-b $\left.{ }^{\prime}\right]$ dithiophene $\left(\mathbf{( 9 )}^{7}\right.$ was synthesized according to the procedure described for 8.7 (660 mg, $3.7 \mathrm{mmol}), \mathrm{KOH}(623$ $\mathrm{mg}, 11.1 \mathrm{mmol})$, hexylbromide (1.83 g, $11.1 \mathrm{mmol})$ and KI (15 mg, $0.1 \mathrm{mmol})$ in $40 \mathrm{~mL}$ DMSO was used. For purification a column chromatography on silica (hexane) yielded bright yellow oil. (1.15 g, $90 \%$ ). ${ }^{1} \mathrm{H} N M R$ (400 MHz, Chloroform-d) $\delta 7.15$ (d, $J=4.8 \mathrm{~Hz}, 2 \mathrm{H}), 6.93(\mathrm{~d}, J=4.9 \mathrm{~Hz}, 2 \mathrm{H}), 1.87-1.78(\mathrm{~m}, 4 \mathrm{H}), 1.24-1.12(\mathrm{~m}, 12 \mathrm{H}), 0.94(\mathrm{~m}$, $4 \mathrm{H}), 0.81(\mathrm{t}, J=6.9 \mathrm{~Hz}, 6 \mathrm{H})$.

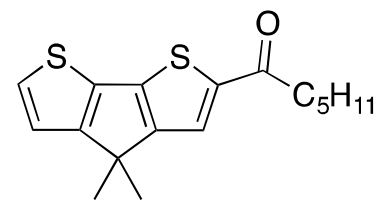

1-(4,4-dimethyl-4H-cyclopenta[2,1-b:3,4- $\left.b^{\prime}\right]$ dithiophen-2-yl)hexan1-one (10) ${ }^{7}$ In the oven dried two-necked flask 8 (490 $\left.\mathrm{mg}, 2.37 \mathrm{mmol}\right)$ was dissolved in dry dichloromethane under nitrogen and hexanoyl chloride was added (320 mg, $2.4 \mathrm{mmol})$. Then reaction mixture was stirred for 30 minutes, cooled to $0{ }^{\circ} \mathrm{C}$ and aluminium chloride $(350 \mathrm{mg}, 2.62 \mathrm{mmol}$ ) was portionwise added. After the reaction mixture was heated up to room temperature and stirred for 24 hours. Then aluminium chloride was quenched with $5 \mathrm{~mL}$ of water and mixture was acidified with $2 \mathrm{M} \mathrm{HCl}$. Organic phase was extracted with dichloromethane, washed with water and dried over magnesium sulfate. Pure product was obtained after column chromatography on silica gel

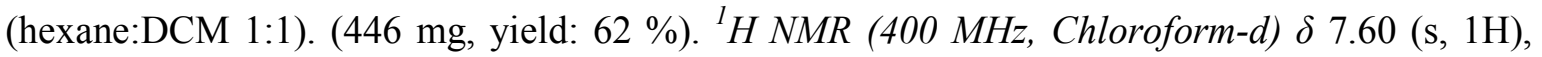
$7.34(\mathrm{~d}, \mathrm{~J}=4.9 \mathrm{~Hz}, 1 \mathrm{H}), 7.03$ (d, J=4.9 Hz, 1H), 2.88 (t, 2H), 1.76 (p, 2H), 1.49 (s, 6H), 1.47-1.33 $(\mathrm{m}, 4 \mathrm{H}), 0.93(\mathrm{t}, 3 \mathrm{H})$.

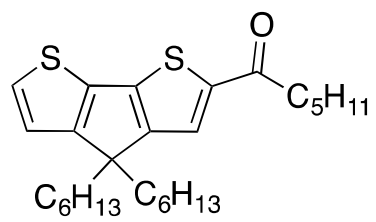

1-(4,4-dihexyl-4H-cyclopenta[1,2-b:5,4-b']dithiophen-2-yl)hexan1-one (11) ${ }^{7}$ was synthesize according to the procedure describe for 10 . 9 (1.15 g, $3.32 \mathrm{mmol})$, hexanoyl chloride (455 mg, $3.4 \mathrm{mmol}), \mathrm{AlCl} 3$ (465 mg, $3.5 \mathrm{mmol}$ ) in $20 \mathrm{ml}$ dry DCM were used. Column chromatography on silica (hex:DCM 2:3) yielded a pure product $(620$ mg, $42 \%) .{ }^{1} H$ NMR (400 MHz, Chloroform-d) $\delta 7.53(\mathrm{~s}, 1 \mathrm{H}), 7.31(\mathrm{~d}, \mathrm{~J}=4.9 \mathrm{~Hz}, 1 \mathrm{H}), 6.95(\mathrm{~d}, \mathrm{~J}$ $=4.9 \mathrm{~Hz}, 1 \mathrm{H}), 2.86(\mathrm{t}, \mathrm{J}=7.5 \mathrm{~Hz}, 2 \mathrm{H}), 1.84(\mathrm{dd}, \mathrm{J}=10.4,6.2 \mathrm{~Hz}, 4 \mathrm{H}), 1.76(\mathrm{p}, \mathrm{J}=7.4 \mathrm{~Hz}, 2 \mathrm{H})$, $1.42-1.32(\mathrm{~m}, \mathrm{~J}=5.2 \mathrm{~Hz}, 4 \mathrm{H}), 1.21-1.06(\mathrm{~m}, 12 \mathrm{H}), 0.97-0.87(\mathrm{~m}, 7 \mathrm{H}), 0.79(\mathrm{t}, \mathrm{J}=6.8 \mathrm{~Hz}$, $6 \mathrm{H})$.

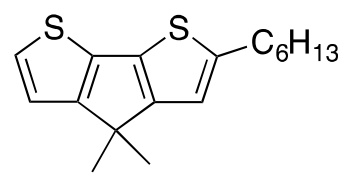

2-hexyl-4,4-dimethyl-4H-cyclopenta[2,1-b:3,4- $b^{\prime}$ ]dithiophene $\mathrm{LiAlH}_{4}(200 \mathrm{mg}, 5.26 \mathrm{mmol})$ and $\mathrm{AlCl}_{3}(666 \mathrm{mg}, 5 \mathrm{mmol})$ were dissolved separately in $6 \mathrm{~mL}$ dry ether each under nitrogen at $0{ }^{\circ} \mathrm{C}$ and then solutions were combined. Afterwards, 10 (446 mg, $1.47 \mathrm{mmol})$ in 6 $\mathrm{mL}$ of dry ether was added via syringe to the mixture at $0{ }^{\circ} \mathrm{C}$. After, ice bath was taken away and mixture was stirred for 4 hours. Then to quench the reaction $1 \mathrm{~mL}$ of ether and $2 \mathrm{~mL}$ of $2 \mathrm{M}$ $\mathrm{HCl}$ was added carefully. Organic phase was extracted with ether washed with water and dried over magnesium sulfate. Pure product was obtained after column chromatography on silica gel 
(hexane). (234 mg, yield: 55\%). ${ }^{1} H$ NMR (400 MHz, Chloroform-d) $\delta 7.14(\mathrm{~d}, \mathrm{~J}=4.9 \mathrm{~Hz}, 1 \mathrm{H})$, $7.03(\mathrm{~d}, \mathrm{~J}=4.9 \mathrm{~Hz}, 1 \mathrm{H}), 6.76(\mathrm{~s}, 1 \mathrm{H}), 2.90$ (t, J=7.7 Hz, 2H), 1.78 (p, J=7.4 Hz, 2H), 1.50 (s, 6H), $1.48-1.24(\mathrm{~m}, 6 \mathrm{H}), 0.99(\mathrm{t}, 3 \mathrm{H})$.

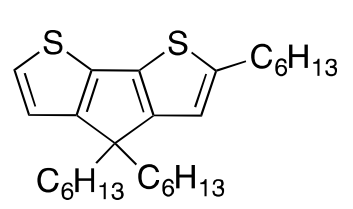

2,4,4-trihexyl-4H-cyclopenta[1,2-b:5,4-b']dithiophene (13). In an oven-dried double-neck flask equipped with a condenser $\mathrm{NaBH}_{4}(190$ $\mathrm{mg}, 5 \mathrm{mmol})$ was dissolved in dry THF $(15 \mathrm{~mL})$ and $\mathrm{AlCl}_{3}(400 \mathrm{mg}, 3$ mmol) was added portionwise. Afterwards, 11 (444 mg, $1 \mathrm{mmol})$ in dry THF $(10 \mathrm{~mL})$ was added via syringe and the reaction mixture was refluxed for the $20 \mathrm{~h}$. Then, the reaction was carefully quenched with icy water, extracted with DCM, washed several times with water and collected organic phases were dried over anhydrous $\mathrm{MgSO}_{4}$. After separation, a filtrate was evaporated to small amount and loaded into column chromatography on silica (hexane) to obtain the pure product. (237 mg, $55 \%$ ). ${ }^{1} \mathrm{H} \mathrm{NMR}$ (400 $M H z$, Chloroform-d) $\delta 7.12(\mathrm{~d}, J=4.8 \mathrm{~Hz}, 1 \mathrm{H}), 6.96(\mathrm{~d}, J=4.8 \mathrm{~Hz}, 1 \mathrm{H}), 6.68(\mathrm{~s}, 1 \mathrm{H}), 2.89$ (t, $J$ $=7.6 \mathrm{~Hz}, 2 \mathrm{H}), 1.88-1.82(\mathrm{~m}, 4 \mathrm{H}), 1.75(\mathrm{p}, J=7.4 \mathrm{~Hz}, 2 \mathrm{H}), 1.49-1.31(\mathrm{~m}, 6 \mathrm{H}), 1.29-1.15$ $(\mathrm{m}, 8 \mathrm{H}), 1.06-0.98(\mathrm{~m}, 7 \mathrm{H}), 0.98-0.93(\mathrm{~m}, 4 \mathrm{H}), 0.88(\mathrm{t}, J=6.9 \mathrm{~Hz}, 6 \mathrm{H})$.

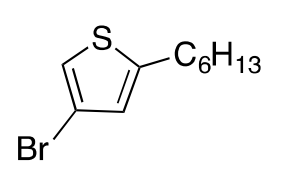

3-bromo-5-hexylthiophene (14). ${ }^{10}$ In the oven-dried Schlenk flask freshly distilled diisopropylamine $(22 \mathrm{~mL}, 156.7 \mathrm{mmol})$ was dissolved in dry THF $(150 \mathrm{~mL})$ and $n$-butyllithium $(2.5 \mathrm{M}, 43.8 \mathrm{~mL})$ was slowly added via syringe at $0{ }^{\circ} \mathrm{C}$. After 20 minutes, 2-bromo-5-hexylthiophene in dry THF $(80 \mathrm{~mL})$ was added via syringe. The reaction mixture was allowed to warm up to room temperature and stirred for 18 hours. Afterwards, the reaction was quenched with water; the organic phase was extracted with dichloromethane and washed several times with deionized water. The organic phase was dried over magnesium sulfate, and concentrated via rotary evaporation. The pure product obtained after column chromatography on silica gel (hexane) $(19.25 \mathrm{~g}$, yield: $86 \%) .{ }^{1} \mathrm{H} \mathrm{NMR}$ (400 MHz, Chloroform-d) $\delta 7.01(\mathrm{~s}, 1 \mathrm{H}), 6.71(\mathrm{~s}, 1 \mathrm{H}), 2.78(\mathrm{t}, \mathrm{J}=7.6 \mathrm{~Hz}, 2 \mathrm{H}), 1.66(\mathrm{p}, \mathrm{J}=7.7 \mathrm{~Hz}$, $2 \mathrm{H}), 1.42-1.28(\mathrm{~m}, 6 \mathrm{H}), 0.91(\mathrm{t}, \mathrm{J}=6.9 \mathrm{~Hz}, 3 \mathrm{H})$.

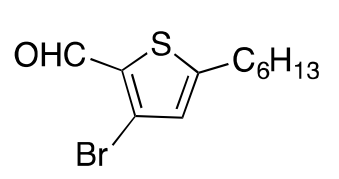

3-bromo-5-hexylthiophene-2-carbaldehyde $\quad(\mathbf{1 5}) .^{11}$ To the freshly prepared lithium diisopropylamide $(77 \mathrm{mmol})$ in THF $(100 \mathrm{~mL}) \mathbf{1 4}(19 \mathrm{~g}$, $77 \mathrm{mmol}$ ) was added dropwise at $0{ }^{\circ} \mathrm{C}$. After stirring the reaction mixture for 1 hour, dimethylformamide $(6 \mathrm{~mL}, 77 \mathrm{mmo})$ was added at $0{ }^{\circ} \mathrm{C}$ and the mixture was allowed to warm up to room temperature and stirred for the following 6 hours. Afterwards, the reaction was quenched with water, organic phase was extracted with dichloromethane, washed with deionized water several times and the organic phase was dried over magnesium sulfate, and solvent was evaporated under vacuum to obtain the product (21.17 g, yield: $99 \%$ ). ${ }^{1} H N M R(400 \mathrm{MHz}$, Chloroform-d) $\delta 9.85(\mathrm{~s}, 1 \mathrm{H}), 6.83(\mathrm{~s}, 1 \mathrm{H}), 2.81(\mathrm{t}, \mathrm{J}=7.7$ $\mathrm{Hz}, 2 \mathrm{H}), 1.65$ (m, 2H), 1.70-1.55 (m, 6H), 0.90-0.83 (m, 3H).

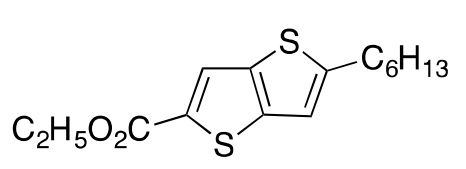

Ethyl 5-hexylthieno[3,2-b]thiophene-2-carboxylate (16). ${ }^{11} 15$ $(21 \mathrm{~g}, 76 \mathrm{mmol})$ was added to the mixture of potassium carbonate $(14 \mathrm{~g}, 0.1 \mathrm{~mol})$ and ethyl 2-sulfanylacetate $(10 \mathrm{~g}, 0.74 \mathrm{mmol})$ in dimethylformamide $(100 \mathrm{~mL})$ and the reaction mixture was stirred for 3 days at room temperature. Afterwards, the reaction mixture was extracted with dichloromethane and washed numerous times with water to delete as much dimethylformamide as possible. The organic phase was dried over magnesium sulfate, concentrated via rotary 
evaporation and column chromatography on silica gel (DCM) was used to obtain a pure product (13.5 g, $62 \%) .{ }^{1} H$ NMR (400 MHz, Chloroform-d) $\delta 7.89$ (s, 1H), 6.95 (s, 1H), 4.36 (q, J=7.1 $\mathrm{Hz}, 2 \mathrm{H}), 2.88$ (t, J=7.6 Hz, 2H), 1.71 (p. J=7.5 Hz, 2H), 1.43-1.24 (m, 9H), 0.89 (m, 3H).

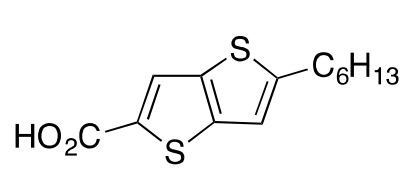

5-hexylthieno[3,2-b]thiophene-2-carboxylic acid (17). ${ }^{11} 16$ (13.5 $\mathrm{g}, 46 \mathrm{mmol})$ and lithium hydroxide monohydrate $(4.2 \mathrm{~g}, 100 \mathrm{mmol})$ were dissolved in a mixture of THF $(100 \mathrm{~mL})$ and water $(100 \mathrm{~mL})$ and the reaction mixture was refluxed for 6 hours. Afterwards, the solvent was evaporated via rotary evaporation to small amount and concentrated hydrochloric acid was added to obtain a white precipitate. Then the mixture was dissolve in chloroform and washed with deionized water. The organic phase was dried over magnesium sulfate and the solvent was evaporated under vacuum to obtain white product. (12.23 g, yield: $99 \%)$. ${ }^{1} \mathrm{H} \mathrm{NMR}$ (400 MHz, Chloroform-d) $\delta 8.03(\mathrm{~s}, 1 \mathrm{H}), 7.29(\mathrm{~s}, 1 \mathrm{H}), 7.02(\mathrm{~s}, 1 \mathrm{H}), 2.94(\mathrm{t}, \mathrm{J}=7.6 \mathrm{~Hz}, 2 \mathrm{H}), 1.76$ (p, J=7.6 Hz, 2H), 1.47-1.28 (m, 6H), 0.94-0.89 (m, 3H).

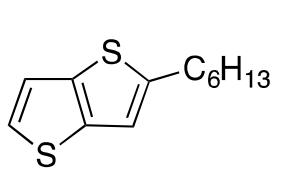

2-hexylthieno[3,2-b]thiophene (18). ${ }^{11}$ To the solution of $\mathbf{1 7}$ (12 g, $\left.45 \mathrm{mmol}\right)$ in quinolone $(50 \mathrm{~mL})$ copper (II) oxide $(1 \mathrm{~g})$ was added and the mixture was refluxed at $260{ }^{\circ} \mathrm{C}$ for 1 hour. Afterwards, the mixture was cooled to room temperature, filtered, extracted with dichloromethane and washed with deionized water. The organic phase was dried over magnesium sulphate, and concentrated ia rotary evaporation. To obtain pure product, column chromatography on silica gel (hexane) was used ( 7.7 g, yield: $76 \%$ ). ${ }^{1} H$ NMR (400 MHz, Chloroform-d) $\delta 7.34(\mathrm{~d}, \mathrm{~J}=5.1 \mathrm{~Hz}, 1 \mathrm{H}), 7.26(\mathrm{~d}$, $\mathrm{J}=5.2 \mathrm{~Hz}, 1 \mathrm{H}), 7.04(\mathrm{~s}, 1 \mathrm{H}), 2.97(\mathrm{t}, \mathrm{J}=7.7 \mathrm{~Hz}, 2 \mathrm{H}), 1.85-1.77(\mathrm{~m}, 2 \mathrm{H}), 1.54-1.38(\mathrm{~m}, 6 \mathrm{H}), 1.03$ $(\mathrm{t}, \mathrm{J}=7.8 \mathrm{~Hz}, 3 \mathrm{H})$.

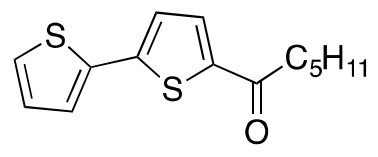

1-([2,2'-bithiophen]-5-yl)hexan-1-one $\quad(\mathbf{1 9})^{\mathbf{1 7}}$ was synthesized according to the procedure described for 10. 2,2'-bithiophene (1.5 g, 9 mmol), hexanoyl chloride $(1.24 \mathrm{~g}, 9.2 \mathrm{mmol})$, aluminum trichloride $(1.24 \mathrm{~g}, 9.3 \mathrm{mmol})$ was used. Column chromatography on silica gel (hexane:DCM 2:1 to 1:1) was used to obtain a pure product (2 g, yield: $84 \%$ ). ${ }^{1} H$ NMR (400 $M H z$, Chloroform-d) $\delta 7.60(\mathrm{~d}, \mathrm{~J}=3.9 \mathrm{~Hz}, 1 \mathrm{H}), 7.33-7.30(\mathrm{~m} ., 2 \mathrm{H}), 7.17(\mathrm{~d}, \mathrm{~J}=4.0 \mathrm{~Hz}, 1 \mathrm{H}), 7.06$ (dd, J=5.0, $3.8 \mathrm{~Hz}, 1 \mathrm{H}), 2.86(\mathrm{t}, \mathrm{J}=7.5 \mathrm{~Hz}, 2 \mathrm{H}), 1.75(\mathrm{p}, \mathrm{J}=7.4 \mathrm{~Hz}, 2 \mathrm{H}), 1.36(\mathrm{~m}, 4 \mathrm{H}), 0.91$ (t, $\mathrm{J}=7.1 \mathrm{~Hz}, 3 \mathrm{H})$.

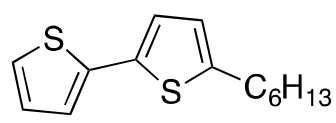

5-hexyl-2,2'-bithiophene (20) synthesized according to the procedure described for 13. ${ }^{17}$ Sodium borohydride (1.43 g, $\left.37.9 \mathrm{mmol}\right)$, aluminum trichloride (3 g, $22.7 \mathrm{mmol})$ and 19 (2 g, $7.57 \mathrm{mmol})$ was used. The product was purified on column chromatography on silica gel (hexane) and yellow oil was obtained (1.22 g, $64 \%) .{ }^{1} H$ NMR (400 MHz, Chloroform-d) $\delta 7.17(\mathrm{~d}, \mathrm{~J}=5.1 \mathrm{~Hz}, 1 \mathrm{H}), 7.11$ (d, $\mathrm{J}=3.6 \mathrm{~Hz}, 1 \mathrm{H}), 7.01(\mathrm{~m}, 2 \mathrm{H}), 6.69(\mathrm{~d}, \mathrm{~J}=3.5 \mathrm{~Hz}), 2.81(\mathrm{t}, \mathrm{J}=7.6 \mathrm{~Hz}, 2 \mathrm{H}), 1.70(\mathrm{p}, \mathrm{J}=7.5 \mathrm{~Hz}, 2 \mathrm{H})$, $1.45-1.30(\mathrm{~m}, 6 \mathrm{H}), 0.96-0.88(\mathrm{~m}, 3 \mathrm{H})$.

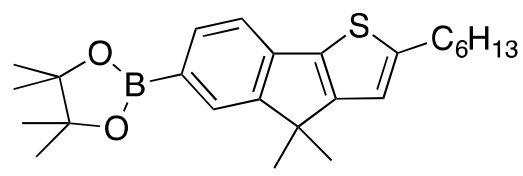

2-(2-hexyl-4,4-dimethyl-4H-indeno[1,2-b]thiophen-6-yl)4,4,5,5-tetramethyl-1,3,2-dioxaborolane (23). ${ }^{7} 4$ (1.4 g, 3.85 $\mathrm{mmol}$ ) was dissolved in $30 \mathrm{~mL}$ of dry THF in oven dried Schlenk flask under nitrogen. Then the solution was cooled down to $-41{ }^{\circ} \mathrm{C}$ by the acetonitrile/dry ice cooling bath. $\mathrm{n}$-BuLi $(2.5 \mathrm{M}$ in hexanes, $1.9 \mathrm{~mL}, 4.74$ 
mmol) was added via syringe dropwise. Then solution was stirred for 2 hours at $-41{ }^{\circ} \mathrm{C}$ and 2isopropoxy-4,4,5,5-tetramethyl-1,3,2-dioxaborolane (0.88 g, $4.74 \mathrm{mmol})$ was added. After, reaction mixture was heated up to room temperature and stirred overnight. Then organic phase was extracted with dichloromethane, washed with water and dried over magnesium sulfate. Pure product was obtained after flash chromatography on silica gel. (hexane :EtOAc 5:1). (0.695 g, yield: $43 \%$ ). ${ }^{1} H$ NMR (400 MHz, Chloroform-d) $\delta 7.78(\mathrm{~s}, 1 \mathrm{H}), 7.76(\mathrm{~d}, \mathrm{~J}=7.4 \mathrm{~Hz}, 1 \mathrm{H}), 7.36(\mathrm{~d}$, $\mathrm{J}=7.4 \mathrm{~Hz}, 1 \mathrm{H}), 6.76(\mathrm{~s}, 1 \mathrm{H}), 2.87$ (t, J=7.3 Hz, 2H), 1,74 (p, J=7.3 Hz, 2H), 1.47 (s, 6H), 1.39 (s, $12 \mathrm{H}), 1.49-1.24(\mathrm{~m}, 6 \mathrm{H}), 0.93(\mathrm{t}, 3 \mathrm{H})$.

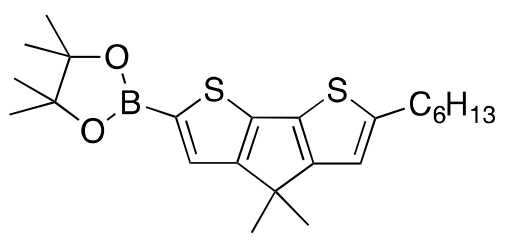

2-(6-hexyl-4,4-dimethyl-4H-cyclopenta[2,1-b:3,4$b^{\prime}$ ]dithiophen-2-yl)-4,4,5,5-tetramethyl-1,3,2-dioxaborolane (24). ${ }^{7}$ In the oven dried Schlenk flask $12(190 \mathrm{mg}, 0.65 \mathrm{mmol})$ was dissolved in $3 \mathrm{~mL}$ of dry THF, then solution was cooled down to $-41{ }^{\circ} \mathrm{C}$ and $\mathrm{n}$-BuLi $(2.5 \mathrm{M}$ in hexane, $0.314 \mathrm{~mL}, 0.78$

$\mathrm{mmol}$ ) was dropwise added. After, reaction mixture was stirred at $-41{ }^{\circ} \mathrm{C}$ for 2 hours, and 2isopropoxy-4,4,5,5-tetramethyl-1,3,2-dioxaborolane (146 mg, $0.78 \mathrm{mmol}$ ) was added. Then, cooling bath was taken away and mixture stirred at room temperature overnight. Organic phase after was extracted with dichloromethane, washed with water and dried over magnesium sulfate. To obtain pure product column chromatography on silica gel was run (EtOAc). (153 mg, 56\%). ${ }^{1} H$ NMR (400 MHz, Chloroform-d) $\delta 7.51(\mathrm{~s}, 1 \mathrm{H}), 6.72(\mathrm{~s}, 1 \mathrm{H}), 2.85(\mathrm{t}, \mathrm{J}=7.7 \mathrm{~Hz}, 2 \mathrm{H}), 1.72(\mathrm{p}$, $\mathrm{J}=7.4 \mathrm{~Hz}, 2 \mathrm{H}), 1.44(\mathrm{~s}, 6 \mathrm{H}), 1.37(\mathrm{~s}, 12 \mathrm{H}), 1.42-1,39$ and 1.36-1.25 (m, 6H), 0.92 (t, J=7.0 Hz, $3 \mathrm{H})$.

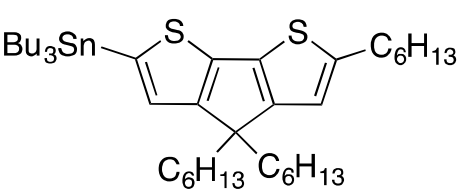

Tributyl(4,4,6-trihexyl-4H-cyclopenta[1,2-b:5,4-b']dithiophen2-yl)stannane (25). In the oven-dried Schlenk flask 13 (248 $\mathrm{mg}$, $0.58 \mathrm{mmol})$ was dissolved in THF $(10 \mathrm{~mL})$ under nitrogen and $n$ BuLi (2.5 M, $0.3 \mathrm{~mL}, 0.75 \mathrm{mmol})$ was added via syringe at $-78^{\circ} \mathrm{C}$. After stirring at this temperature for 2 hours, tributyltin chloride $(244 \mathrm{mg}, 0.75 \mathrm{mmol})$ was added at $-78{ }^{\circ} \mathrm{C}$ and the reaction mixture was allowed to warm up to room temperature naturally and was stirred for the following 6 hours. Afterwards, the reaction was quenched with water, organic phase was extracted with dichloromethane and washed with deionized water. The organic phase was dried over magnesium sulfate and solvent was evaporated under vacuum. Product was not purified and yield was considered as $100 \%$, which is consistent with ${ }^{1} \mathrm{H}$ NMR analysis. ${ }^{1} \mathrm{H} N M R$ (400 MHz, Chloroform-d) $\delta 6.88(\mathrm{~s}, 1 \mathrm{H}), 6.60(\mathrm{~s}, 1 \mathrm{H}), 2.82(\mathrm{t}, \mathrm{J}=7.5 \mathrm{~Hz}, 2 \mathrm{H}), 1.77(\mathrm{~m}, 2 \mathrm{H}), 1.71$ $1.51(\mathrm{~m}, 4 \mathrm{H}), 1.41-1.24(\mathrm{~m}, 4 \mathrm{H}), 1.2-1.08(\mathrm{~m}, 6 \mathrm{H}), 1.00-0.86(\mathrm{~m}, 10 \mathrm{H}), 0.81(\mathrm{t}, \mathrm{J}=6.9 \mathrm{~Hz}, 12 \mathrm{H})$.

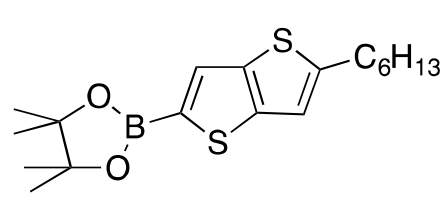

2-(5-hexylthieno[3,2-b]thiophen-2-yl)-4,4,5,5-tetramethyl-1,3,2dioxaborolane (26) was synthesized according to the procedure described for $\mathbf{2 4} .^{15} \mathbf{1 8}$ (2.27 g, $\left.10.1 \mathrm{mmol}\right), 2.5 \mathrm{M}$-BuLi solution in hexanes (4.9 $\mathrm{mL}, 12.15 \mathrm{mmol}), 2$ 2-isopropoxy-4,4,5,5tetramethyl-1,3,2-dioxaborolane $(2.26 \mathrm{~g}, 12.2 \mathrm{mmol})$ in dry THF $(20 \mathrm{~mL})$ was used. A flash chromatography on silica (hexanes) was used to obtain the pure product. (3.32 g, $94 \%) .{ }^{1} H$ NMR (400 MHz, Chloroform-d) $\delta 7.75$ (s, 1H), $6.98(\mathrm{~s}, 1 \mathrm{H}), 2.89$ (t, J $=7.5 \mathrm{~Hz}, 2 \mathrm{H}), 1.75(\mathrm{t}, J=7.4 \mathrm{~Hz}, 2 \mathrm{H}), 1.48-1.32(\mathrm{~m}, 18 \mathrm{H}), 0.96(\mathrm{~m}, 3 \mathrm{H})$.

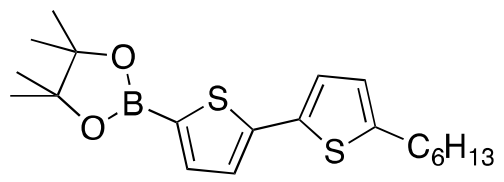

2-(5'-hexyl-[2,2'-bithiophen]-5-yl)-4,4,5,5-tetramethyl-1,3,2dioxaborolane (27). ${ }^{14}$ In the oven-dried Schlenk flask 5-hexyl- 
2,2'-bithiophene (1.22 g, $4.9 \mathrm{mmol})$ was dissolved in dry THF $(20 \mathrm{~mL})$ and $n$-butyllithium $(2.5$ $\mathrm{M}, 2.4 \mathrm{~mL}, 5.9 \mathrm{mmol}$ ) was added dropwise at $-78{ }^{\circ} \mathrm{C}$. After stirring for 2 hours 2 -isopropoxy4,4,5,5-tetramethyl-1,3,2-dioxaborolane $(1.1 \mathrm{~g}, 5.9 \mathrm{mmol})$ was added at the same temperature and the reaction mixture was stirred for the following 6 hours allowing to warm up to room temperature. Afterwards, the reaction was quenched with water, organic phase was extracted with dichloromethane, washed with deionized water; the organic phase was dried over magnesium sulfate and concentrated via rotary evaporation. The pure product was obtained after flash column on silica (DCM) $(625 \mathrm{mg}, 34 \%) .{ }^{1} H$ NMR (400 MHz, Chloroform-d) $\delta 7.55$ (d, $\mathrm{J}=3.6 \mathrm{~Hz}, 1 \mathrm{H}), 7.19(\mathrm{~d}, \mathrm{~J}=3.6 \mathrm{~Hz}, 1 \mathrm{H}), 7.07(\mathrm{~d}, \mathrm{~J}=3.5 \mathrm{~Hz}, 1 \mathrm{H}), 6.70(\mathrm{~d}, \mathrm{~J}=3.6 \mathrm{~Hz}, 1 \mathrm{H}), 2.80(\mathrm{t}$, $\mathrm{J}=7.6 \mathrm{~Hz}, 2 \mathrm{H}), 1.70$ (p, J=7.6 Hz, 2H), 1.49-1.31 (m, 18H), 0.94 (t, J=7.1 Hz, 3H).

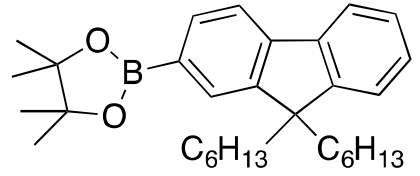

mmol), potassium

2-(9,9-dihexyl-9H-fluoren-2-yl)-4,4,5,5-tetramethyl-1,3,2dioxaborolane (28). ${ }^{16}$ In the oven dried Schlenk tube 2-bromo-9,9dihexyl-9H-fluorene (850 mg, $2.06 \mathrm{mmol}), 4,4,4^{\prime}, 44^{\prime}, 5,5,5^{\prime}, 5^{\prime}-$ octamethyl-2,2'-bi(1,3,2-dioxaborolane) $\quad\left(\mathrm{B}_{2} \mathrm{Pin}_{2}\right) \quad(574 \mathrm{mg}, 2.26$ acetate $\quad(606 \quad \mathrm{mg}, \quad 6.2 \mathrm{mmo})$ and $\left[1,1^{\prime}-\right.$ bis(diphenylphosphino)ferrocene]dichloropalladium (II) $\left(\mathrm{Pd}(\mathrm{dppf}) \mathrm{Cl}_{2}\right)(90 \mathrm{mg}, 0.12 \mathrm{mmol}$ ) were degassed under vacuum and refilled with nitrogen, then dry 1,4-dioxane $(20 \mathrm{~mL})$ was added. The reaction mixture was stirred at $80{ }^{\circ} \mathrm{C}$ for 6 hours and then cooled down, extracted with dichloromethane, washed with deionized water. The organic phase was dried over magnesium sulfate, concentrated to small amount via rotary evaporation. The Pure product was obtained after column chromatography on silica gel (Hexane:DCM 1:1). (881 mg, yield: $93 \%) .{ }^{1} H$ NMR (400 MHz, Dichloromethane- $\left.d_{2}\right) \delta 7.87(\mathrm{~m}, 2 \mathrm{H}), 7.84-7.79(\mathrm{~m}, 2 \mathrm{H}), 7.47-7.38(\mathrm{~m}, 3 \mathrm{H}), 2.11(\mathrm{~d}$, $\mathrm{J}=8.2 \mathrm{~Hz}, 4 \mathrm{H}), 1.46(\mathrm{~s}, 12 \mathrm{H}), 1.24-1.07(\mathrm{~m}, 16 \mathrm{H}), 0.85$ (t, J=7.1 Hz, 6H).

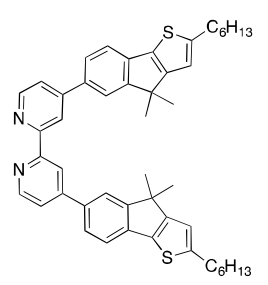

4,4'-bis(2-hexyl-4,4-dimethyl-4H-indeno[1,2-b]thiophen-6-yl)-2,2'bipyridine (29). ${ }^{7} 8 \mathrm{~mL}$ of $2 \mathrm{M}$ water solution of potassium carbonate and 30 $\mathrm{mL}$ of toluene with 23 (600 mg, $1.47 \mathrm{mmol}$ ) and 4,4'-dibromo-2,2'-bipyridine (182 $\mathrm{mg}, 0.58 \mathrm{mmol}$ ) were purged for 20 minutes with nitrogen in Schlenk tube. Then $\mathrm{Pd}\left(\mathrm{PPh}_{3}\right)_{4}(56 \mathrm{mg}, 0,048 \mathrm{mmol})$ was added; tube was capped and reaction mixture was heated up to $85{ }^{\circ} \mathrm{C}$ and stirred for 24 hours. Then mixture was cooled down to room temperature, organic phase was extracted with dichloromethane, washed with water, dried over magnesium sulfate and evaporated to minimal amount. Pure component was obtained by column chromatography on silica gel (Hexane:EtOAc 1:3). (373 mg, yield: $89 \%$ ). ${ }^{1} H$ NMR (400 MHz, Chloroform-d) $\delta 8.81$ (d, J=1.3 Hz, 2H), 8.79 (d, J=5.2 Hz, 2H), $7.80(\mathrm{~d}, \mathrm{~J}=1.7 \mathrm{~Hz}, 2 \mathrm{H}), 7.71(\mathrm{dd}, \mathrm{J}=7.9,1.7 \mathrm{~Hz}, 2 \mathrm{H}), 7.63$ (dd, J=5.2, $1.9 \mathrm{~Hz}, 2 \mathrm{H}), 7.46$ (d, $\mathrm{J}=7.9 \mathrm{~Hz}, 2 \mathrm{H}), 6.79$ (s, 2H), 2.89 (t, J=7.7 Hz, 4H), 1.76 (p, J=7.4 Hz, 4H), 1.55 (s, 13H), 1.49$1.24(\mathrm{~m}, 12 \mathrm{H}), 0.94(\mathrm{t}, \mathrm{J}=7.0 \mathrm{~Hz}, 6 \mathrm{H})$.

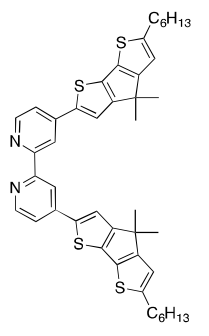

4,4'-bis(6-hexyl-4,4-dimethyl-4H-cyclopenta[2,1-b:3,4- $b$ ']dithiophen-2-yl)2,2'-bipyridine (30). ${ }^{7}$ This compound was synthesize by the procedure absolutely similar for the synthesis of 29. From $24(153 \mathrm{mg}, 0.36 \mathrm{mmol})$ product was obtained (120 mg, yield: 83\%). ${ }^{1} H$ NMR (400 MHz, Chloroform-d) $\delta 8.67-8.62(\mathrm{~m}$, 4H), 7.63 (s, 2H), 7.46 (d, J=3.6 Hz, 2H), 6.74 (s, 2H), 2.86 (t, J=7.8 Hz, 4H), 1,73 (p, J=7.6 Hz, 4H), 1.49 (s, 12H), 1.45-1.28 (m, 6H), 0.92 (t, J=6.6 Hz, 6H). 


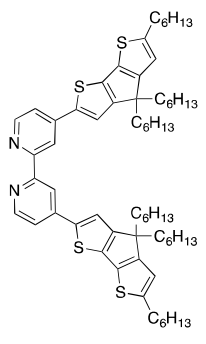

4,4'-bis(6-hexyl-4,4-dihexyl-4H-cyclopenta[2,1-b:3,4- $b$ ']dithiophen-2-yl)-2,2'bipyridine (31). ${ }^{7}$ In the oven-dried Schlenk tube $25(0.58 \mathrm{mmol}), 4,4$ '-dibromo2,2'-bipyridine (60 mg, $0.19 \mathrm{mmol}$ ) and tetrakis(triphenylphosphine)palladium(0) $\left(\mathrm{Pd}\left(\mathrm{PPh}_{3}\right)_{4}\right)(33 \mathrm{mg}, 0.03 \mathrm{mmol})$ were degassed under high vacuum and refilled with nitrogen and then dry dimethylformamide $(10 \mathrm{~mL})$ was added via syringe and the mixture was stirred at $85^{\circ} \mathrm{C}$ for 12 hours. After completion, the reaction mixture was extracted with dichloromethane, washed several times with deionized water, organic phase was dried over magnesium sulfate and concentrated via rotary evaporation. The pure product was obtained after column chromatography on silica (DCM-methanoltriethylamine 98-2-0.1) (120 mg, $62 \%) .{ }^{1} H$ NMR (400 MHz, Chloroform-d) $\delta 8.64(\mathrm{~m}, 4 \mathrm{H}), 7.56$ (s, 2H), $7.46(\mathrm{~d}, \mathrm{~J}=5.2 \mathrm{~Hz}, 2 \mathrm{H}), 6.65(\mathrm{~s}, 1 \mathrm{H}), 2.86(\mathrm{t}, \mathrm{j}=7.6 \mathrm{~Hz}, 4 \mathrm{H}), 1.85$ (dd, J=11.1, $5.6 \mathrm{~Hz}$, $8 \mathrm{H}), 1.71$ (p, J=7.4 Hz, 4H), 1.44-1.08 (m, 26H), $0.94(\mathrm{~m}, 30 \mathrm{H}), 0.81(\mathrm{t}, \mathrm{J}=6.7 \mathrm{~Hz}, 6 \mathrm{H}) .{ }^{13} \mathrm{C} \mathrm{NMR}$ (101 MHz, Chloroform-d) 158.84, 157.70, 156.43, 149.63, 148.34, 143.58, 139.62, 139.50, 133.31, 120.35, 119.06, 118.94, 116.11, 54.01, 37.91, 31.78, 31.67, 31.58, 31.06, 29.75, 28.72, 24.54, 22.67, 22.62, 14.10, 14.07. DEPT $135{ }^{13} \mathrm{C} \mathrm{NMR}$ (101 MHz, Chloroform-d) $\delta=\mathrm{CH}-$ : $149.63,120.35,119.06,118.94,116.11 ;-\mathrm{CH}_{2}-:$ 37.91, 31.78, 31.67, 31.58 31.06, 29.75, 28.72, 24.54, 22.67, 22.62; $-\mathrm{CH}_{3}: 14.10,14.07$.

4,4'-bis(5-hexylthieno[3,2-b]thiophen-2-yl)-2,2'-bipyridine (32) was synthesized according to the procedure described for $29 .{ }^{12} 26$ (3.32 g, $\left.9.5 \mathrm{mmol}\right), 4,4$ '-dibromo2,2'-bipyridine (785 mg, $2.5 \mathrm{mmol}), \mathrm{Pd}\left(\mathrm{PPh}_{3}\right)_{4}(250 \mathrm{mg}, 0.2 \mathrm{mmol})$ in $2.5 \mathrm{M}$ aqueous solution $\mathrm{K} 2 \mathrm{CO} 3(10 \mathrm{~mL})$ and toluene $(40 \mathrm{~mL})$ was used. After column chromatography (DCM:EtOAc $=9: 1)$ the pure product was obtained. $(630 \mathrm{mg}, 42$ \%). ${ }^{1} H$ NMR (400 MHz, Chloroform-d) $\delta 8.66(\mathrm{~m}, 4 \mathrm{H}), 7.77(\mathrm{~s}, 2 \mathrm{H}), 7.49(\mathrm{~d}, \mathrm{~J}=5.1 \mathrm{~Hz}, 2 \mathrm{H})$, $7.26(\mathrm{~s}, 2 \mathrm{H}), 6.98(\mathrm{~s}, 2 \mathrm{H}), 2.90(\mathrm{t}, \mathrm{J}=7.6 \mathrm{~Hz}, 4 \mathrm{H}), 1.74(\mathrm{p}, \mathrm{J}=7.5 \mathrm{~Hz}, 4 \mathrm{H}), 1.45-1.27(\mathrm{~m}$, 12H), 0.89 (t, 6H). ${ }^{13} \mathrm{C} \mathrm{NMR}(101 \mathrm{MHz}$, Chloroform-d) 156.48, 150.49, 149.74, 143.08, 141.02, 139.76, 138.19, 119.54, 118.14, 116.89, 116.54, 31.58, 31.47, 31.31, 28.79, 22.59, 14.11 DEPT $135{ }^{13} \mathrm{C}$ NMR (101 MHz, Chloroform-d) $\delta=\mathrm{CH}-:$ 156.48, 150.49, 149.74, 143.08, 141.02, 139.76, 138.19, 119.54, 118.14, 116.89, 116.54; $-\mathrm{CH}_{2}-:$ 31.58, 31.47, 31.31, 28.79, 22.59; - $\mathrm{CH}_{3}$ : 14.11.

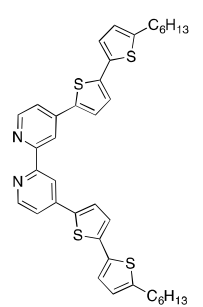

4,4'-bis(5'-hexyl-[2,2'-bithiophen]-5-yl)-2,2'-bipyridine (33) was synthesized according to the procedure described for 29. ${ }^{13} 27$ (625 $\left.\mathrm{mg}, 1.66 \mathrm{mmol}\right), 4,4$ 'dibromo-2,2'-bipyridine (157 mg, $0.5 \mathrm{mmol}), \mathrm{Pd}\left(\mathrm{PPh}_{3}\right)_{4}$ in $2 \mathrm{M}$ solution aqueous potassium carbonate solution $(10 \mathrm{~mL})$ and toluene $(40 \mathrm{~mL})$ were used. Column chromatography on silica gel (DCM-methanol-NEt 3 98-2-0.1) was used to obtain pure product (250 mg, $77 \%$ ). ${ }^{1} H$ NMR (400 MHz, Chloroform-d) $\delta 8.67(\mathrm{~d}, \mathrm{~J}=5.2$ $\mathrm{Hz}, 2 \mathrm{H}), 8.63$ (d, J=1.7 Hz, 2H), 7.56 (d, J=3.8 Hz, 2H), 7.48 (dd, J=5.2, $1.9 \mathrm{~Hz}, 2 \mathrm{H}), 7.13$ (d, $\mathrm{J}=3.9 \mathrm{~Hz}, 2 \mathrm{H}), 7.07$ (d, J=3.5 Hz, 2H), 6.72 (d, J=3.6 Hz, 2H), 2.81 (t, J=7.6 Hz, 4H), 1.70 (p, $\mathrm{J}=7.6 \mathrm{~Hz}, 4 \mathrm{H}), 1.44-1.27(\mathrm{~m}, 12 \mathrm{H}), 0.93-0.87(\mathrm{~m}, 6 \mathrm{H}) .{ }^{13} \mathrm{C} \mathrm{NMR}$ (101 MHz, Chloroform-d) $156.48,149.71,146.44,142.20,139.91,139.03,134.23,126.44,125.02,124.11,123.96,119.50$, 116.87, 31.58, 30.24, 28.78, 22.60, 14.11. DEPT $135{ }^{13} \mathrm{C} \mathrm{NMR} \mathrm{(101} \mathrm{MHz,} \mathrm{Chloroform-d)} \delta$ $=\mathrm{CH}-:$ 149.71, 126.44, 125.02, 124.11, 123.96, 119.50, 116.87; - $\mathrm{CH}_{2}-: 31.58,30.24,28.78$, $22.60 ;-\mathrm{CH}_{3}: 14.11$. 
4,4'-bis(9,9-dihexyl-9H-fluoren-2-yl)-2,2'-bipyridine (34) was synthesized according to the procedure described for the 29.28 (875 $\mathrm{mg}, 1.9 \mathrm{mmol}), 4,4$ 'dibromo-2,2'-bipyridine (251 mg, $0.8 \mathrm{mmol}), \mathrm{Pd}\left(\mathrm{PPh}_{3}\right)_{4}(116 \mathrm{mg}, 0.1 \mathrm{mmol})$ in 2 $\mathrm{M}$ aqueous solution of potassium carbonate $(10 \mathrm{~mL})$ and toluene $(40 \mathrm{~mL})$ was used. Column on silica (DCM:EtAc 9:1) was used to obtain a pure product (490 mg, 74 \%). ${ }^{1} H$ NMR (400 MHz, Dichlorormethane- $\left.d_{2}\right) \delta 8.93(\mathrm{~d}, \mathrm{~J}=1.7 \mathrm{~Hz}, 2 \mathrm{H}), 8.81(\mathrm{~d}, \mathrm{~J}=5.1$ $\mathrm{Hz}, 2 \mathrm{H}), 7.91-7.80$ (m, 8H), 7.70 (dd, J=5.1, $1.9 \mathrm{~Hz}, 2 \mathrm{H}), 7.46-7.37$ (m, 6H), 2.12 (d, J=10.1 Hz, $8 \mathrm{H}), 1.21-1.05(\mathrm{~m}, 24 \mathrm{H}), 0.79(\mathrm{t}, \mathrm{J}=7.0 \mathrm{~Hz}, 12 \mathrm{H}), 0.7(\mathrm{~m}, 8 \mathrm{H}).) .{ }^{13} \mathrm{C} \mathrm{NMR}(101 \mathrm{MHz}$, Dichloromethane- $\left.d_{2}\right) 156.77,151.78,151.24,149.60,142.34,140.45,137.14,127.59,126.93$, $126.14,123.05,121.73,121.46,120.23,120.04,118.85,40.38,31.57,29.71,23.87,22.61$, 13.84. DEPT $135{ }^{13} \mathrm{C}$ NMR (101 MHz, Dichloromethane- $\left.d_{2}\right) \delta=\mathrm{CH}-:$ 149.60, 127.59, 126.93, $126.14,123.05,121.73,121.46,120.23,120.04,118.85 ;-\mathrm{CH}_{2}-: 40.38,31.57,29.71,23.87,22.61$; $-\mathrm{CH}_{3}: 13.84$.

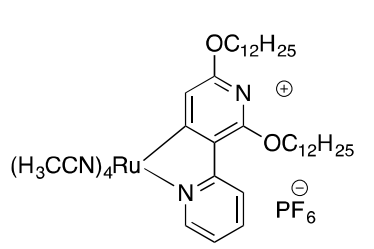

$\left[\mathbf{R u}\left(\mathbf{C}^{\wedge} \mathbf{N}\right)\left(\mathbf{C H}_{3} \mathbf{C N}\right)_{4}\right]\left(\mathbf{P F}_{6}\right) .{ }^{1} \quad$ In the oven-dried Schlenk flask $\left[\mathrm{Ru}\left(\mathrm{C}_{6} \mathrm{H}_{6}\right) \mathrm{Cl}(\mu-\mathrm{Cl})\right]_{2} \quad(370 \mathrm{mg}, 0.74 \mathrm{mmol}), 2$ ',6'-dodecyloxy-2,3'bipyridine (796 mg, $1.5 \mathrm{mmol}, 2$ equiv.), potassium hydroxide powder (85 mg, $1.5 \mathrm{mmol}, 2$ equiv) and potassium hexafluorophosphate (554

$\mathrm{mg}, 3 \mathrm{mmol}, 4$ equiv) were degassed and flushed with nitrogen. Then, $20 \mathrm{~mL}$ of dry acetonitrile was added by syringe. The reaction mixture was heated up to $50{ }^{\circ} \mathrm{C}$ and stirred for three days. After, while hot, the reaction mixture was filtered; the filtrate was evaporated and the pure product was obtained after column chromatography on basic aluminium oxide with gradient eluent (acetonitrile in dichloromethane 0-10\%). (777 mg, yield: $55 \%$ ). ${ }^{1} H$ NMR (400 MHz, Acetonitrile-d $\left.d_{3}\right) \delta 8.89(\mathrm{~d}, \mathrm{~J}=5.4 \mathrm{~Hz}, 1 \mathrm{H}), 8.44(\mathrm{~d}, \mathrm{~J}=8.3 \mathrm{~Hz}, 1 \mathrm{H}), 7.70$ (ddd, $\mathrm{J}=8.6,7.4,1.7 \mathrm{~Hz}, 1 \mathrm{H}), 7.06(\mathrm{ddd}, \mathrm{J}=7.3,5.7,1.5 \mathrm{~Hz}, 1 \mathrm{H}), 6.95(\mathrm{~s}, 1 \mathrm{H}), 4.47$ (t, J=6.7 Hz, 2H), $4.32(\mathrm{t}, \mathrm{J}=6.8 \mathrm{~Hz}, 2 \mathrm{H}), 2.51(\mathrm{~s}, 3 \mathrm{H}), 2.16(\mathrm{~s}, 3 \mathrm{H}), 2.03(\mathrm{~s}, 6 \mathrm{H}), 1.89$ (p, J=6.9 Hz, 2H), 1.78 (p, $\mathrm{J}=6.9 \mathrm{~Hz}, 2 \mathrm{H}), 1.58-1.23(\mathrm{~m}, 40 \mathrm{H}), 0.88(\mathrm{t}, 6 \mathrm{H})$.

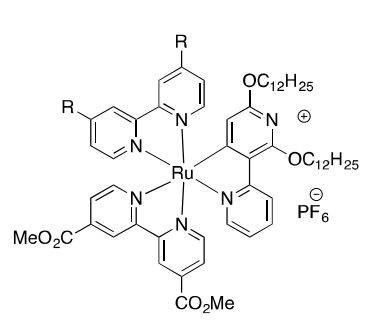

General procedure for the synthesis $\left[\mathrm{Ru}\left(\mathrm{C}^{\wedge} \mathrm{N}\right)\left(\mathrm{L}^{\mathrm{aux}}\right)\left(\operatorname{bpy}\left(\mathrm{CO}_{2} \mathrm{Me}\right)_{2}\right)\right]\left(\mathrm{PF}_{6}\right){ }^{1}$ Auxiliary $(\mathbf{2 9}, \mathbf{3 0}, 31,32,33$ and 34, 1 equiv.) and anchoring (4,4'-dicarboxy-2,2'-bipyridine methyl ester, 1 equiv.) ligands and $20 \mathrm{~mL}$ of absolute ethanol:chloroform $(3: 1)$ in the flask with condenser were heated up to $70{ }^{\circ} \mathrm{C}$ until all ligands dissolved. Then $\left[\mathrm{Ru}\left(\mathrm{C}^{\wedge} \mathrm{N}\right)\left(\mathrm{CH}_{3} \mathrm{CN}\right)_{4}\right]\left(\mathrm{PF}_{6}\right)$ (1 equiv.) was added and reaction mixture was refluxed for 3 hours under nitrogen. Then mixture was evaporated to the small amount and column chromatography on silica gel with gradient eluent (acetonitrile in dichloromethane 0-10\%) resulted in 3 bands representing the following complexes in the order of decreasing $R_{f}$ : bis-heteroleptic complex with two auxiliary ligands, tris-heteroleptic complex and bis-heteroleptic complex with two anchoring ligands. [We must note that we were not able to separate some of the non-hydrolyzed dyes, especially SA25 from free 4,4'-dimethyldicarboxy-2,2'-bipyridine, which was separated by filtering several times through celite after hydrolysis. This was possible due to bad solubility of 4,4'dicarboxy-2,2'-bipyridine in dichloromethane.] 


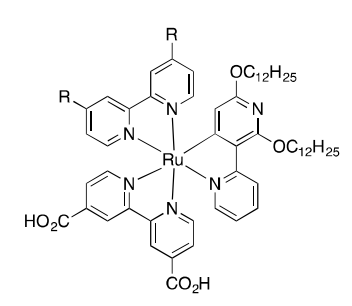

$\begin{array}{llcllr}\text { General } & \text { procedure } & \text { for } & \text { the } & \text { synthesis } & \text { of } \\ {\left[\operatorname{Ru}\left(\mathrm{C}^{\wedge} \mathrm{N}\right)\left(\mathrm{L}^{\text {aux }}\right)\left(\operatorname{bpy}\left(\mathrm{CO}_{2} \mathrm{H}_{2}\right)\right]\left(\mathrm{PF}_{6}\right) .\right.} & & & \text { The }\end{array}$ $\left[\mathrm{Ru}\left(\mathrm{C}^{\wedge} \mathrm{N}\right)\left(\mathrm{L}^{\mathrm{aux}}\right)\left(\mathrm{bpy}\left(\mathrm{CO}_{2} \mathrm{Me}\right)_{2}\right)\right]\left(\mathrm{PF}_{6}\right)$ was dissolved in $5 \mathrm{ml}$ of DMF: $\mathrm{H}_{2} \mathrm{O}: \mathrm{NEt}_{3}(3: 1: 1)$ and reaction mixture was refluxed for one day under nitrogen. Afterwards, the reaction mixture was extracted with dichloromethane and washed with $0.1 \%$ aqueous $\mathrm{HPF}_{6}$ solution. The organic phase was dried over magnesium sulfate, concentrated to small amount via rotary evaporation and purified on size exclusive column on Sephadex LH-20.

$\left[\mathbf{R u}\left(\mathbf{C}^{\wedge} \mathbf{N}\right)(\mathbf{2 9})\left(\mathbf{b p y}\left(\mathbf{C O}_{2} \mathbf{M e}_{2}\right)\right]\left(\mathbf{P F}_{6}\right) \quad\left(\mathbf{S A}^{20}\right)\right.$. Was synthesized according to the general procedure. $\left[\mathrm{Ru}\left(\mathrm{C}^{\wedge} \mathrm{N}\right)\left(\mathrm{CH}_{3} \mathrm{CN}\right)_{4}\right]\left(\mathrm{PF}_{6}\right)(161 \mathrm{mg}, 0.17 \mathrm{mmol}), 29$ (124 mg, $\left.0.17 \mathrm{mmol}\right), 4,4$ 'dicarboxy-2,2'-bipyridine methyl ester (47 mg, $0.17 \mathrm{mmol}$ ) was used. (121 mg, 40\%).

${ }^{1} H$ NMR (400 MHz, Chloroform-d) $\delta 8.93(\mathrm{~s}, 1 \mathrm{H}), 8.83(\mathrm{~s}, 1 \mathrm{H}), 8.61(\mathrm{~d}, \mathrm{~J}=8.4 \mathrm{~Hz}, 1 \mathrm{H}), 8.47$ (d, $\mathrm{J}=6.1 \mathrm{~Hz}, 1 \mathrm{H}), 8.44(\mathrm{~d}, \mathrm{~J}=7.4 \mathrm{~Hz}, 2 \mathrm{H}), 8.22(\mathrm{~d}, \mathrm{~J}=5.6 \mathrm{~Hz}, 1 \mathrm{H}), 8.10(\mathrm{~d}, \mathrm{~J}=5.5 \mathrm{~Hz}, 1 \mathrm{H}), 7.75$ $(\mathrm{s}, 1 \mathrm{H}), 7.71(\mathrm{~d}, \mathrm{~J}=6.0 \mathrm{~Hz}, 1 \mathrm{H}), 7.67(\mathrm{~s}, 1 \mathrm{H}), 7.65-7.57(\mathrm{~m}, 4 \mathrm{H}), 7.52(\mathrm{dd}, \mathrm{J}=5.9,1.9 \mathrm{~Hz}$, $1 \mathrm{H}), 7.49-7.40(\mathrm{~m}, 4 \mathrm{H}), 7.39(\mathrm{dd}, \mathrm{J}=6.1,1.8 \mathrm{~Hz}, 1 \mathrm{H}), 6.84(\mathrm{t}, \mathrm{J}=6.6 \mathrm{~Hz}, 1 \mathrm{H}), 6.77(\mathrm{~s}, 2 \mathrm{H})$, $5.68(\mathrm{~s}, 1 \mathrm{H}), 4.53-4.42(\mathrm{~m}, 2 \mathrm{H}), 4.16(\mathrm{~d}, \mathrm{~J}=7.4 \mathrm{~Hz}, 2 \mathrm{H}), 4.03(\mathrm{~s}, 3 \mathrm{H}), 3.99(\mathrm{~s}, 3 \mathrm{H}), 2.87(\mathrm{t}, \mathrm{J}=$ $7.7 \mathrm{~Hz}, 4 \mathrm{H}), 1.92$ (m, 2H), 1.79-1.61 (m, 6H), 1.59-1.17 (m, 60H), 0.93-0.82 (m, 12H).

MALDI TOF: $\mathrm{m} / \mathrm{z}=1617.6307[\mathrm{M}]+\left(\right.$ calcd for $\left.\left[\mathrm{RuC}_{116} \mathrm{H}_{119} \mathrm{~N}_{6} \mathrm{O}_{6} \mathrm{~S}_{2}\right]^{+}: \mathrm{m} / \mathrm{z}=1617.7675\right)$.

$\left[\mathbf{R u}\left(\mathbf{C}^{\wedge} \mathbf{N}\right)(30)\left(b_{p y}\left(\mathbf{C O}_{2} \mathbf{M e}\right)_{2}\right)\right]\left(\mathbf{P F}_{6}\right) \quad\left(\mathbf{S A}^{2}-23\right)$. Was synthesized according to the general procedure. SA-17 (49 mg, $0.05 \mathrm{mmol}), 30$ (38 mg, $0.05 \mathrm{mmol})$, 4,4'-dicarboxy-2,2'-bipyridine methyl ester (14 mg, $0.05 \mathrm{mmol}$ ) was used. (27 mg, yield: $30 \%)$.

${ }^{1} H$ NMR (400 MHz, Chloroform-d) $\delta 8.92(\mathrm{~s}, 1 \mathrm{H}), 8.81(\mathrm{~s}, 1 \mathrm{H}), 8.58(\mathrm{~d}, J=8.5 \mathrm{~Hz}, 1 \mathrm{H}), 8.43(\mathrm{~d}$, $J=6.0 \mathrm{~Hz}, 1 \mathrm{H}), 8.30(\mathrm{dd}, J=10.5,2.0 \mathrm{~Hz}, 2 \mathrm{H}), 8.15(\mathrm{~d}, J=5.7 \mathrm{~Hz}, 1 \mathrm{H}), 8.03(\mathrm{dd}, J=5.7,1.6$ $\mathrm{Hz}, 1 \mathrm{H}), 7.74(\mathrm{~d}, J=12.7 \mathrm{~Hz}, 2 \mathrm{H}), 7.68(\mathrm{dd}, J=5.9,1.8 \mathrm{~Hz}, 1 \mathrm{H}), 7.63-7.55(\mathrm{~m}, 1 \mathrm{H}), 7.44(\mathrm{~d}, J$ $=6.2 \mathrm{~Hz}, 1 \mathrm{H}), 7.40-7.30(\mathrm{~m}, 2 \mathrm{H}), 7.29-7.25(\mathrm{~m}, 1 \mathrm{H}), 7.22(\mathrm{dd}, J=6.2,1.9 \mathrm{~Hz}, 1 \mathrm{H}), 6.80$ (ddd, $J=7.3,5.6,1.5 \mathrm{~Hz}, 1 \mathrm{H}), 6.73(\mathrm{~d}, J=2.8 \mathrm{~Hz}, 2 \mathrm{H}), 5.65(\mathrm{~s}, 1 \mathrm{H}), 4.46(\mathrm{t}, J=6.6 \mathrm{~Hz}, 2 \mathrm{H})$, $4.18-4.11(\mathrm{~m}, 2 \mathrm{H}), 4.02(\mathrm{~s}, 3 \mathrm{H}), 4.00(\mathrm{~s}, 3 \mathrm{H}), 2.84(\mathrm{t}, J=7.7 \mathrm{~Hz}, 4 \mathrm{H}), 1.91(\mathrm{p}, J=6.9 \mathrm{~Hz}, 2 \mathrm{H})$, $1.75-1.61(\mathrm{~m}, 6 \mathrm{H}), 1.57-1.16(\mathrm{~m}, 60 \mathrm{H}), 0.93-0.82(\mathrm{~m}, 12 \mathrm{H})$.

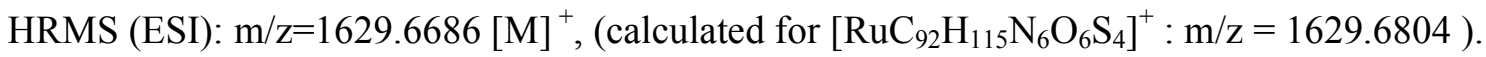

$\left[\mathbf{R u}\left(\mathbf{C}^{\wedge} \mathbf{N}\right)(\mathbf{2 9})\left(\mathbf{b p y}\left(\mathbf{C O}_{2} \mathbf{H}_{2}\right)\right]\left(\mathbf{P F}_{6}\right) \quad\left(\mathbf{S A}^{22}\right)\right.$ was synthesized according to the general procedure. SA-20 (70 mg, $0.04 \mathrm{mmol}$ ) was used. (68 mg, $100 \%$ ).

HRMS (ESI): $\mathrm{m} / \mathrm{z}=1589.7490[\mathrm{M}]^{+}$, (calculated for $\left[\mathrm{RuC}_{94} \mathrm{H}_{115} \mathrm{~N}_{6} \mathrm{O}_{6} \mathrm{~S}_{2}\right]^{+}: \mathrm{m} / \mathrm{z}=1589.7363$ ).

$\left[\mathbf{R u}\left(\mathbf{C}^{\wedge} \mathbf{N}\right)(\mathbf{3 0})\left(\mathbf{b p y}\left(\mathbf{C O}_{2} \mathbf{H}_{2}\right)\right]\left(\mathbf{P F}_{6}\right) \quad(\mathbf{S A - 2 5})\right.$ was synthesized according to the general procedure. SA-23 (27 mg, $0.015 \mathrm{mmol}$ ) was used. (26 mg, $100 \%$ ).

MALDI TOF: $\mathrm{m} / \mathrm{z}=1601.4746[\mathrm{M}]^{+}\left(\right.$calcd for $\left.\left[\mathrm{RuC}_{90} \mathrm{H}_{111} \mathrm{~N}_{6} \mathrm{O}_{6} \mathrm{~S}_{2}\right]^{+}: \mathrm{m} / \mathrm{z}=1601.6491\right)$. 
$\left[\mathbf{R u}\left(\mathbf{C}^{\wedge} \mathbf{N}\right)(32)\left(\operatorname{bpy}\left(\mathbf{C O}_{2} \mathbf{M e}_{2}\right)\right]\left(\mathbf{P F}_{6}\right) \quad\left(\mathbf{S A}^{2}-25\right)\right.$ was synthesized according to the general procedure. 32 (100 mg, $0.17 \mathrm{mmol}$ ), dimethyl 2,2'-bipyridine-4,4'-dicarboxylate (45.3 $\mathrm{mg}, 0.17$ $\mathrm{mmol})$ and $\left[\mathrm{Ru}\left(\mathrm{C}^{\wedge} \mathrm{N}\right)\left(\mathrm{CH}_{3} \mathrm{CN}\right)_{4}\right]\left(\mathrm{PF}_{6}\right)(155.5 \mathrm{mg}, 0.17 \mathrm{mmol})$ were used. (79.4 mg, 29\%).

${ }^{1} H$ NMR (400 MHz, Chloroform-d) $\delta 8.92(\mathrm{~s}, 1 \mathrm{H}), 8.82(\mathrm{~d}, J=1.8 \mathrm{~Hz}, 1 \mathrm{H}), 8.60(\mathrm{~d}, J=8.4 \mathrm{~Hz}$, $1 \mathrm{H}), 8.42(\mathrm{~d}, J=5.9 \mathrm{~Hz}, 1 \mathrm{H}), 8.28(\mathrm{~s}, 1 \mathrm{H}), 8.23(\mathrm{~s}, 1 \mathrm{H}), 8.20(\mathrm{~d}, J=5.7 \mathrm{~Hz}, 1 \mathrm{H}), 8.06(\mathrm{~d}, J=5.6$ Hz, 1H), $7.83(\mathrm{~s}, 1 \mathrm{H}), 7.72(\mathrm{~s}, 1 \mathrm{H}), 7.67$ (dd, $J=6.0,1.7 \mathrm{~Hz}, 1 \mathrm{H}), 7.60$ (t, $J=7.9 \mathrm{~Hz}, 1 \mathrm{H}), 7.54$ $(\mathrm{d}, J=6.1 \mathrm{~Hz}, 1 \mathrm{H}), 7.41-7.36(\mathrm{~m}, 1 \mathrm{H}), 7.34-7.29(\mathrm{~m}, 2 \mathrm{H}), 7.18(\mathrm{~d}, J=5.4 \mathrm{~Hz}, 1 \mathrm{H}), 6.94(\mathrm{~s}$, $1 \mathrm{H}), 6.91(\mathrm{~s}, 1 \mathrm{H}), 6.84(\mathrm{t}, J=6.6 \mathrm{~Hz}, 1 \mathrm{H}), 5.66(\mathrm{~s}, 1 \mathrm{H}), 4.52-4.40(\mathrm{~m}, 2 \mathrm{H}), 4.23-4.07(\mathrm{~m}$, 2H), $4.03(\mathrm{~s}, 3 \mathrm{H}), 4.00(\mathrm{~s}, 3 \mathrm{H}), 2.90-2.81(\mathrm{~m}, 4 \mathrm{H}), 1.91(\mathrm{p}, J=6.9 \mathrm{~Hz}, 4 \mathrm{H}), 1.76-1.47(\mathrm{~m}$, $10 \mathrm{H}), 1.44-1.09(\mathrm{~m}, 42 \mathrm{H}), 0.92-0.81(\mathrm{~m}, 12 \mathrm{H})$.

DEPT $135{ }^{13} \mathrm{C}$ NMR (101 MHz, Chloroform-d) $\delta=C H-:$ 155.24, 150.00, 149.92, 149.67, 149.42, $136.11,127,34,125.24,122.57,122.46,122.43,122.16,121.90,120.89,119.87,119.72,117.86$, 117.62, 116.43, 116.38, 107.21; $-\mathrm{CH}_{2^{-}}: 31.94,31.92,31.55,31.54,31.37,29.72,29.68,29.64$, $29.62,29.57,29.56,29.48,29.39 .29 .36,29.31,29.27,29.81,26.52,26.12,22.71,22.69$, 22.59; $\mathrm{CH}_{3}: 53.33,53.26,14.14,14.13,14.10$.

HRMS (ESI): $\mathrm{m} / \mathrm{z}=1497.6611[\mathrm{M}]^{+}$, (calculated for $\left[\mathrm{RuC}_{82} \mathrm{H}_{103} \mathrm{~N}_{6} \mathrm{O}_{6} \mathrm{~S}_{4}\right]^{+}: \mathrm{m} / \mathrm{z}=1497.5885$ ).

$\left[\mathbf{R u}\left(\mathbf{C}^{\wedge} \mathbf{N}\right)(32)\left(\mathbf{b p y}\left(\mathbf{C O}_{2} \mathbf{H}_{2}\right)\right]\left(\mathbf{P F}_{6}\right) \quad\left(\mathbf{S A}^{246}\right)\right.$ was synthesized according to the general procedure. SA-245 (75 mg, $0.04 \mathrm{mmol})$ in $\mathrm{DMF}_{\mathrm{NEt}}: \mathrm{H}_{2} \mathrm{O}(3: 1: 1)(10 \mathrm{~mL})$ was used. $(68.5 \mathrm{mg}$, $98 \%)$.

${ }^{1} H$ NMR (400 MHz, Chloroform-d) $\delta 11.16(\mathrm{~s}, 1 \mathrm{H}), 9.93(\mathrm{~s}, 1 \mathrm{H}), 9.82(\mathrm{~s}, 1 \mathrm{H}), 8.63(\mathrm{~d}, J=8.5$ $\mathrm{Hz}, 1 \mathrm{H}), 8.36-8.20(\mathrm{~m}, 3 \mathrm{H}), 8.08(\mathrm{~d}, J=5.9 \mathrm{~Hz}, 1 \mathrm{H}), 8.02(\mathrm{~d}, J=5.9 \mathrm{~Hz}, 1 \mathrm{H}), 7.83-7.75(\mathrm{~m}$, 2H), $7.70(\mathrm{~s}, 1 \mathrm{H}), 7.58(\mathrm{~d}, J=7.0 \mathrm{~Hz}, 2 \mathrm{H}), 7.47(\mathrm{~d}, J=6.2 \mathrm{~Hz}, 1 \mathrm{H}), 7.40(\mathrm{~d}, J=5.6 \mathrm{~Hz}, 1 \mathrm{H})$, $7.29-7.24(\mathrm{~m}, 1 \mathrm{H}), 7.18(\mathrm{~d}, J=6.2 \mathrm{~Hz}, 1 \mathrm{H}), 6.96(\mathrm{~d}, J=9.1 \mathrm{~Hz}, 2 \mathrm{H}), 6.77(\mathrm{t}, J=6.7 \mathrm{~Hz}, 1 \mathrm{H})$, $5.72(\mathrm{~s}, 1 \mathrm{H}), 4.54-4.43(\mathrm{~m}, 2 \mathrm{H}), 4.17(\mathrm{~m}, 2 \mathrm{H}), 2.95-2.84(\mathrm{~m}, 4 \mathrm{H}), 1.92(\mathrm{q}, J=7.3 \mathrm{~Hz}, 2 \mathrm{H})$, $1.83-1.06(\mathrm{~m}, 54 \mathrm{H}), 0.88(\mathrm{~m}, 12 \mathrm{H})$.

${ }^{13} \mathrm{C} N M R\left(101 \mathrm{MHz}\right.$, Dichloromethane-d $\left.d_{2}\right) \delta 167.78,165.49,160.85,159.72,158.54,156.16$, $155.94,154.37,152.29,149.85,149.62,149.37,148.52,148.49,140.65,140.39,140.24,136.72$, $138.62,135.72,127.11,126.85,125.81,125.78,124.41,124.31,122.91,122.57,121.85,121.77$, $120.42,120.27,119.34,119.18,117.75,117.58,116.48,107.26,66.06,65.90,46.04,31.93$, $31.91,31.54,31.42,31.37,29.65,29.72,29.67,29.62,29.56,29.48,29.38,29.35,29.33,29.29$, $28.79,26.51,26.13,22.71,22.68,22.58,14.14,14.13,14.10,8.45$.

DEPT $135{ }^{13} \mathrm{C}$ NMR (101 MHz, Dichloromethane-d 2$) \delta=C H-:$ 154.37, 149.85, 149.62, 149.37, $148.52,135.72,127.11,126.85,124.41,124.31,122.57,121.85,121.77,120.42,119.34,119.18$, 117.75, 117.58, 116.48, 107.26; - $\mathrm{CH}_{2^{-}}: 66.14$, 65.71, 66.06, 65.90, 46.04, 31.93, 31.91, 31.54, $31.42,31.37,29.65,29.72,29.67,29.62,29.56,29.48,29.38,29.35,29.33,29.29,28.79,26.51$, $26.13,22.71,22.68,22.58 ;-\mathrm{CH}_{3}: 14.14,14.13,14.10,8.45$.

HRMS (ESI): $\mathrm{m} / \mathrm{z}=1469.5587[\mathrm{M}]^{+}$, (calculated for $\left[\mathrm{RuC}_{80} \mathrm{H}_{99} \mathrm{~N}_{6} \mathrm{O}_{6} \mathrm{~S}_{4}\right]^{+}: \mathrm{m} / \mathrm{z}=1469.5571$ ).

$\left[\mathbf{R u}\left(\mathbf{C}^{\wedge} \mathbf{N}\right)(\mathbf{3 4})\left(\mathbf{b p y}\left(\mathbf{C O}_{2} \mathbf{M e}_{2}\right)\right]\left(\mathbf{P F}_{6}\right) \quad\left(\mathbf{S A}^{2} \mathbf{2 7 4}\right)\right.$ was synthesized according to the general procedure. 34 (300 $\mathrm{mg}, 0.37 \mathrm{mmol})$, dimethyl 2,2'-bipyridine-4,4'-dicarboxylate $(99.5 \mathrm{mg}, 0.37$ $\mathrm{mmol})$ and $\left[\mathrm{Ru}\left(\mathrm{C}^{\wedge} \mathrm{N}\right)\left(\mathrm{CH}_{3} \mathrm{CN}\right)_{4}\right]\left(\mathrm{PF}_{6}\right)(341 \mathrm{mg}, 0.37 \mathrm{mmol})$ were used. Yield: $(216 \mathrm{mg}, 31 \%)$. 
${ }^{1} H$ NMR (400 MHz, Chloroform-d) $\delta 8.95(\mathrm{~d}, J=1.5 \mathrm{~Hz}, 1 \mathrm{H}), 8.85(\mathrm{~d}, J=1.7 \mathrm{~Hz}, 1 \mathrm{H}), 8.60(\mathrm{~d}, J$ $=8.1 \mathrm{~Hz}, 1 \mathrm{H}), 8.50-8.46(\mathrm{~m}, 3 \mathrm{H}), 8.28(\mathrm{~d}, J=5.6 \mathrm{~Hz}, 1 \mathrm{H}), 8.12(\mathrm{dd}, J=5.7,1.6 \mathrm{~Hz}, 1 \mathrm{H}), 7.86$ $(\mathrm{d}, J=4.3 \mathrm{~Hz}, 1 \mathrm{H}), 7.84(\mathrm{~d}, J=4.3 \mathrm{~Hz}, 1 \mathrm{H}), 7.79(\mathrm{dd}, J=8.0,1.7 \mathrm{~Hz}, 1 \mathrm{H}), 7.77-7.68(\mathrm{~m}, 6 \mathrm{H})$, $7.66-7.58(\mathrm{~m}, 3 \mathrm{H}), 7.50(\mathrm{~d}, J=6.1 \mathrm{~Hz}, 1 \mathrm{H}), 7.49-7.44(\mathrm{~m}, 2 \mathrm{H}), 7.38-7.35(\mathrm{~m}, 6 \mathrm{H}), 6.88$ (ddd, $J=7.3,5.6,1.5 \mathrm{~Hz}, 1 \mathrm{H}), 5.67(\mathrm{~s}, 1 \mathrm{H}), 4.53-4.41(\mathrm{~m}, 2 \mathrm{H}), 4.26-4.10(\mathrm{~m}, 2 \mathrm{H}), 4.04(\mathrm{~s}$, $3 \mathrm{H}), 4.01(\mathrm{~s}, 3 \mathrm{H}), 2.07-1.98(\mathrm{~m}, 8 \mathrm{H}), 1.96-1.86(\mathrm{~m}, 2 \mathrm{H}), 1.75-1.63(\mathrm{~m}, 2 \mathrm{H}), 1.62-1.49(\mathrm{~m}$, $4 \mathrm{H}), 1.47-1.18(\mathrm{~m}, 34 \mathrm{H}), 1.14-0.96(\mathrm{~m}, 22 \mathrm{H}), 0.91-0.83(\mathrm{~m}, 8 \mathrm{H}), 0.77-0.69(\mathrm{~m}, 12 \mathrm{H}), 0.66$ $-0.55(\mathrm{~m}, 6 \mathrm{H})$.

${ }^{13}$ C NMR (101 MHz, Chloroform-d) $\delta 165.21,164.62,164.39,160.66,159.52,158.45,156.84$, $155.65,155.3,154.64,152.16,152.08,151.25,151.18,150.31,150.07,149.85,149.48,147.96$, $147.54,143.31,143.14,140.08,139.94,137.05,136.14,135.26,134.93,134.72,128.02,127.89$, $127.54,127.06,126.99,126.21,126.05,125.13,124.96,124.43,123.00,122.55,122.41,121.27$, $120.96,120.67,120.62,120.41,120.30,120.27,120.07,107.35,66.09,65.90,55.45,53.34$, 53.27 , 40.47, 40.43, 31.94, 31.92, 31.54, 31.51, 29.69, 29.66, 29.62, 29.55, 29.53, 29.39, 29.36, $29.32,26.51,26.13,23.82,22.71,22.69,22.59,22.58,14.14,14.13,14.00$.

DEPT $135{ }^{13}$ C NMR (101 MHz, Chloroform-d) $\delta=C H-:$ 155.30, 150.31, 150.07, 149.85, 149.48, 136.14, 128.02, 127.89, 127.54, 127.06, 126.99, 126.21, 126.05, 125.13, 124.96, 124.43, 123.00, $122.55,122.41,121.27,120.96,120.67,120.62,120.41,120.30,120.27,107.35$; $-\mathrm{CH}_{2^{-}}: 66.09$, $65.90,55.45,40.47,40.43,31.94,31.92$, 31.54, 31.51, 29.69, 29.66, 29.62, 29.55, 29.53, 29.39, 29.36, 29.32, 26.51, 26.13, 23.82, 22.71, 22.69, 22.59, 22.58; $-\mathrm{CH}_{3}: 53.34,53.27,14.14,14.13$, 14.00 .

$\left[\mathbf{R u}\left(\mathbf{C}^{\wedge} \mathbf{N}\right)(\mathbf{3 4})\left(\mathbf{b p y}\left(\mathbf{C O}_{2} \mathbf{H}\right)_{2}\right)\right]\left(\mathbf{P F}_{6}\right) \quad(\mathbf{S A - 2 8 2})$ was synthesized according to the general procedure. SA-274 (215 mg, $0.115 \mathrm{mmol})$ in DMF: $\mathrm{NEt}_{3}: \mathrm{H}_{2} \mathrm{O}(3: 1: 1)(10 \mathrm{~mL})$ was used. Yield: $206 \mathrm{mg}, 96 \%$.

${ }^{1} H$ NMR (400 MHz, Dichloromethane-d 2$) \delta 9.80(\mathrm{~s}, 1 \mathrm{H}), 9.69(\mathrm{~s}, 1 \mathrm{H}), 8.65(\mathrm{~d}, J=8.4 \mathrm{~Hz}, 1 \mathrm{H})$, $8.56(\mathrm{dd}, J=7.0,1.9 \mathrm{~Hz}, 2 \mathrm{H}), 8.33(\mathrm{~d}, J=5.8 \mathrm{~Hz}, 1 \mathrm{H}), 8.01-7.93(\mathrm{~m}, 2 \mathrm{H}), 7.89$ (d, $J=8.0 \mathrm{~Hz}$, $1 \mathrm{H}), 7.87(\mathrm{~d}, J=8.0 \mathrm{~Hz}, 1 \mathrm{H}), 7.81-7.68(\mathrm{~m}, 10 \mathrm{H}), 7.60$ (ddd, $J=8.7,7.4,1.7 \mathrm{~Hz}, 1 \mathrm{H}), 7.53$ $(\mathrm{dd}, J=6.1,1.9 \mathrm{~Hz}, 1 \mathrm{H}), 7.50(\mathrm{dd}, J=5.8,1.4 \mathrm{~Hz}, 1 \mathrm{H}), 7.47$ (dd, $J=6.1,1.8 \mathrm{~Hz}, 1 \mathrm{H}), 7.43-$ $7.35(\mathrm{~m}, 7 \mathrm{H}), 6.76(\mathrm{ddd}, J=7.3,5.6,1.5 \mathrm{~Hz}, 1 \mathrm{H}), 5.68(\mathrm{~s}, 1 \mathrm{H}), 4.48(\mathrm{t}, J=6.8 \mathrm{~Hz}, 2 \mathrm{H}), 4.21-$ $4.10(\mathrm{~m}, 2 \mathrm{H}), 2.11-1.99(\mathrm{~m}, 8 \mathrm{H}), 1.98-1.86(\mathrm{~m}, 2 \mathrm{H}), 1.64(\mathrm{p}, J=6.9 \mathrm{~Hz}, 2 \mathrm{H}), 1.60-1.50(\mathrm{~m}$, $4 \mathrm{H}), 1.48-1.17(\mathrm{~m}, 34 \mathrm{H}), 1.16-0.95(\mathrm{~m}, 22 \mathrm{H}), 0.94-0.80(\mathrm{~m}, 8 \mathrm{H}), 0.79-0.68(\mathrm{~m}, 12 \mathrm{H}), 0.68$ $-0.54(\mathrm{~m}, 6 \mathrm{H})$.

${ }^{13} \mathrm{C}$ NMR (101 MHz, Dichloromethane-d $\left.d_{2}\right) \delta 167.45,165.59,160.68,159.61,158.41,156.90$, $156.77,155.86,154.22$, 152.14, 152.11, 151.20, 151.19, 149.96, 149.47, 148.08, 146.74, 143.19, $143.13,140.01,139.99,135.48,135.20,128.00,127.95,127.05,127.01,126.85,125.94,125.90$, $124.30,124.16,124.03,123.09,123.08,122.48,121.18,121.13,120.55,120.48,120.27,120.19$, $120.06,120.03$, 107.37, 66.00, 65.64, 55.44, 45.56, 40.35, 31.94, 31.91, 31.53, 29.71, 29.66, $29.51,29.48,29.38,29.35,26.47,26.11,23.82,22.71,22.69,22.54,13.91,13.89,13.76,8.42$.

DEPT $135{ }^{13} \mathrm{C} N M R\left(101 \mathrm{MHz}\right.$, Dichloromethane-d $\left.d_{2}\right) \delta=C H-:$ 154.22, 149.96, 149.47, 148.08, $135.48,128.00,127.95,127.05,127.01,126.85,125.94,125.90,124.30,124.16,124.03,123.09$, $123.08,122.48,121.18,121.13,120.55,120.48,120.19,120.06,120.03,107.37$; $-\mathrm{CH}_{2^{-}}: 66.00$, 
$65.64,55.44,45.56,40.35,31.94,31.91,31.53,29.71,29.66,29.51,29.48,29.38,29.35,26.47$, $26.11,23.82,22.71,22.69,22.54 ;-\mathrm{CH}_{3}: 13.91,13.89,13.76,8.42$.

HRMS (ESI): $\mathrm{m} / \mathrm{z}=1689.9517[\mathrm{M}]^{+}$, (calculated for $\left[\mathrm{RuC}_{106} \mathrm{H}_{135} \mathrm{~N}_{6} \mathrm{O}_{6}\right]^{+}: \mathrm{m} / \mathrm{z}=1689.7665$ ).

$\left[\mathbf{R u}\left(\mathbf{C}^{\wedge} \mathbf{N}\right)(33)\left(\operatorname{bpy}\left(\mathrm{CO}_{2} \mathbf{M e}_{2}\right)\right]\left(\mathbf{P F}_{6}\right) \quad\left(\mathrm{SA}^{2}-281\right)\right.$ was synthesized according to the general procedure. 33 (78.2 $\mathrm{mg}, 0.12 \mathrm{mmol}$ ), dimethyl 2,2'-bipyridine-4,4'-dicarboxylate (32.6 mg, 0.12 $\mathrm{mmol})$ and $\left[\mathrm{Ru}\left(\mathrm{C}^{\wedge} \mathrm{N}\right)\left(\mathrm{CH}_{3} \mathrm{CN}\right)_{4}\right]\left(\mathrm{PF}_{6}\right)(112 \mathrm{mg}, 0.12 \mathrm{mmol})$ were used. Yield: $(51 \mathrm{mg}, 25 \%)$.

${ }^{1} H_{N M R}\left(400 \mathrm{MHz}\right.$, Dichloromethane- $\left.d_{2}\right) \delta 8.97(\mathrm{~s}, 1 \mathrm{H}), 8.87(\mathrm{~s}, 1 \mathrm{H}), 8.65(\mathrm{~d}, J=8.4 \mathrm{~Hz}, 1 \mathrm{H})$, 8.47 (d, $J=6.0 \mathrm{~Hz}, 1 \mathrm{H}), 8.27$ (d, $J=17.0 \mathrm{~Hz}, 2 \mathrm{H}), 8.09$ (d, $J=5.7 \mathrm{~Hz}, 1 \mathrm{H}), 7.96$ (d, $J=7.2 \mathrm{~Hz}$, 1H), 7.69 (dd, $J=6.0,1.7 \mathrm{~Hz}, 1 \mathrm{H}), 7.65$ (t, $J=8.8 \mathrm{~Hz}, 1 \mathrm{H}), 7.59$ (d, $J=3.9 \mathrm{~Hz}, 1 \mathrm{H}), 7.55$ (d, $J=$ $6.1 \mathrm{~Hz}, 1 \mathrm{H}), 7.48$ (d, $J=3.9 \mathrm{~Hz}, 1 \mathrm{H}), 7.39$ (d, $J=6.1 \mathrm{~Hz}, 1 \mathrm{H}), 7.33$ (d, $J=6.4 \mathrm{~Hz}, 2 \mathrm{H}), 7.24$ $(\mathrm{dd}, J=6.2,1.8 \mathrm{~Hz}, 1 \mathrm{H}), 7.18(\mathrm{~d}, J=3.8 \mathrm{~Hz}, 1 \mathrm{H}), 7.13-7.09(\mathrm{~m}, 3 \mathrm{H}), 6.79(\mathrm{t}, J=7.0 \mathrm{~Hz}, 1 \mathrm{H})$, $6.76-6.74(\mathrm{~m}, 2 \mathrm{H}), 5.65(\mathrm{~s}, 1 \mathrm{H}), 4.52-4.42(\mathrm{~m}, 2 \mathrm{H}), 4.21-4.10(\mathrm{~m}, 2 \mathrm{H}), 4.01(\mathrm{~s}, 6 \mathrm{H}), 2.82(\mathrm{t}$, $J=6.4 \mathrm{~Hz}, 2 \mathrm{H}), 1.91(\mathrm{p}, J=6.9 \mathrm{~Hz}, 2 \mathrm{H}), 1.74-1.64(\mathrm{~m}, 4 \mathrm{H}), 1.64-1.48(\mathrm{~m}, 4 \mathrm{H}), 1.46-1.12$ $(\mathrm{m}, 46 \mathrm{H}), 0.94-0.81(\mathrm{~m}, 12 \mathrm{H})$.

${ }^{13} \mathrm{C} N M R$ (101 MHz, Dichloromethane-d $\left.d_{2}\right) \delta 165.39,164.22,164.17,160.93,159.75,158.00$, $156.50,155.83,155.33,155.23,149.71,149.61,149.37,149.34,147.55,141.58,141.55,140.11$, $140.03,137.03,136.50,136.39,136.23,135.25,133.51,133.46,128.08,128.02,126.65,125.36$, $125.31,124.79,124.44,122.75,122.61,121.83,121.81,120.55,119.81,117.83,117.69,107.25$, $66.18,65.78,53.28,53.20,31.93,31.91,31.56,30.17,29.71,29.66,29.63,29.61,29.50,29.44$, $29.37,29.35,29.29,28.74,26.45,26.09,22.70,22.59,13.89,13.85$.

DEPT $135{ }^{13} \mathrm{C}$ NMR (101 MHz, Dichloromethane-d $\left.d_{2}\right) \delta=C H-: 155.33,149.71,149.61,149.37$, $149.34,136.23,128.08,128.02,126.65,125.36,125.31,124.79,124.44,122.75,122.61,121.83$, $121.81,120.55,117.83,117.69,107.25$; $-\mathrm{CH}_{2^{-}}:$66.18, 65.78, 31.93, 31.91, 31.56, 30.17, 29.71, $29.66,29.63,29.61,29.50,29.44,29.37,29.35,29.29,28.74,26.45,26.09,22.70,22.59$; $-\mathrm{CH}_{3}$ : $53.28,53.20,13.89,13.85$.

HRMS (ESI): $\mathrm{m} / \mathrm{z}=14549.4463[\mathrm{M}]^{+}$, (calculated for $\left[\mathrm{RuC}_{86} \mathrm{H}_{107} \mathrm{~N}_{6} \mathrm{O}_{6} \mathrm{~S}_{4}\right]^{+}: \mathrm{m} / \mathrm{z}=1549.6200$ ).

\section{$\left[\mathrm{Ru}\left(\mathrm{C}^{\wedge} \mathrm{N}\right)(33)\left(\mathrm{bpy}\left(\mathrm{CO}_{2} \mathrm{H}\right)_{2}\right)\right]\left(\mathrm{PF}_{6}\right)(\mathrm{SA}-284)$}

${ }^{1} H$ NMR (400 MHz, Dichloromethane-d 2$) \delta 12.02(\mathrm{~s}, 1 \mathrm{H}), 9.79(\mathrm{~s}, 1 \mathrm{H}), 9.68(\mathrm{~s}, 1 \mathrm{H}), 8.61(\mathrm{~d}, J=$ $8.4 \mathrm{~Hz}, 1 \mathrm{H}), 8.29$ (d, $J=5.9 \mathrm{~Hz}, 1 \mathrm{H}), 8.24$ (d, $J=13.8 \mathrm{~Hz}, 2 \mathrm{H}), 7.98$ (d, $J=5.5 \mathrm{~Hz}, 1 \mathrm{H}), 7.90$ $(\mathrm{d}, J=5.6 \mathrm{~Hz}, 1 \mathrm{H}), 7.73(\mathrm{~d}, J=5.0 \mathrm{~Hz}, 1 \mathrm{H}), 7.57(\mathrm{~m}, 3 \mathrm{H}), 7.47(\mathrm{dd}, J=12.3,4.9 \mathrm{~Hz}, 2 \mathrm{H}), 7.39$ $(\mathrm{d}, J=5.6 \mathrm{~Hz}, 1 \mathrm{H}), 7.26(\mathrm{~d}, J=6.1 \mathrm{~Hz}, 1 \mathrm{H}), 7.21-7.03(\mathrm{~m}, 5 \mathrm{H}), 6.78-6.70(\mathrm{~m}, 3 \mathrm{H}), 5.63(\mathrm{~s}$, $1 \mathrm{H}), 4.45$ (t, $J=6.7 \mathrm{~Hz}, 2 \mathrm{H}), 4.12(\mathrm{~d}, J=6.7 \mathrm{~Hz}, 2 \mathrm{H}), 2.85-2.77(\mathrm{~m}, 4 \mathrm{H}), 1.95-1.82(\mathrm{~m}, 2 \mathrm{H})$, $1.73-1.47(\mathrm{~m}, 16 \mathrm{H}), 1.42-1.09(\mathrm{~m}, 38 \mathrm{H}), 0.95-0.77(\mathrm{~m}, 12 \mathrm{H})$.

HRMS (ESI): $\mathrm{m} / \mathrm{z}=1521.4067[\mathrm{M}]^{+}$, (calculated for $\left[\mathrm{RuC}_{84} \mathrm{H}_{103} \mathrm{~N}_{6} \mathrm{O}_{6} \mathrm{~S}_{4}\right]^{+}: \mathrm{m} / \mathrm{z}=1521.5886$ ).

$\left[\mathbf{R u}\left(\mathbf{C}^{\wedge} \mathbf{N}\right)(31)\left(\operatorname{bpy}\left(\mathbf{C O}_{2} \mathbf{M e}\right)_{2}\right)\right]\left(\mathbf{P F}_{6}\right) \quad(\mathbf{S A}-283)$ was synthesized according to the general procedure. 31 (120 mg, $0.118 \mathrm{mmol}$ ), dimethyl 2,2'-bipyridine-4,4'-dicarboxylate (32 $\mathrm{mg}, 0.118$ $\mathrm{mmol})$ and $\left[\mathrm{Ru}\left(\mathrm{C}^{\wedge} \mathrm{N}\right)\left(\mathrm{CH}_{3} \mathrm{CN}\right)_{4}\right]\left(\mathrm{PF}_{6}\right)(110 \mathrm{mg}, 0.118 \mathrm{mmol})$ were used. Yield: $(94 \mathrm{mg}, 38 \%$ ). 
${ }^{1} H$ NMR (400 MHz, Dichloromethane- $\left.d_{2}\right) \delta 8.98(\mathrm{~s}, 1 \mathrm{H}), 8.88(\mathrm{~s}, 1 \mathrm{H}), 8.63(\mathrm{~d}, J=8.4 \mathrm{~Hz}, 1 \mathrm{H})$, $8.47(\mathrm{~d}, J=5.9 \mathrm{~Hz}, 1 \mathrm{H}), 8.29(\mathrm{~d}, J=9.1 \mathrm{~Hz}, 2 \mathrm{H}), 8.15(\mathrm{~d}, J=5.6 \mathrm{~Hz}, 1 \mathrm{H}), 7.96(\mathrm{~d}, J=5.6 \mathrm{~Hz}$, $1 \mathrm{H}), 7.70(\mathrm{~d}, J=6.0 \mathrm{~Hz}, 1 \mathrm{H}), 7.63(\mathrm{t}, J=7.9 \mathrm{~Hz}, 1 \mathrm{H}), 7.55(\mathrm{~d}, J=7.6 \mathrm{~Hz}, 2 \mathrm{H}), 7.50(\mathrm{~d}, J=6.2$ $\mathrm{Hz}, 1 \mathrm{H}), 7.40-7.25(\mathrm{~m}, 4 \mathrm{H}), 6.79(\mathrm{t}, J=6.6 \mathrm{~Hz}, 1 \mathrm{H}), 6.73(\mathrm{~d}, J=2.8 \mathrm{~Hz}, 2 \mathrm{H}), 5.62(\mathrm{~s}, 1 \mathrm{H})$, $4.50-4.44(\mathrm{~m}, 2 \mathrm{H}), 4.21-4.09(\mathrm{~m}, 2 \mathrm{H}), 4.02(\mathrm{~s}, 3 \mathrm{H}), 4.01(\mathrm{~s}, 3 \mathrm{H}), 2.92-2.83(\mathrm{~m}, 4 \mathrm{H}), 1.95-$ $1.85(\mathrm{~m}, 8 \mathrm{H}), 1.78-1.48(\mathrm{~m}, 10 \mathrm{H}), 1.48-1.05(\mathrm{~m}, 78 \mathrm{H}), 1.00-0.77(\mathrm{~m}, 24 \mathrm{H})$.

${ }^{13}$ C NMR (101 MHz, Dichloromethane- $\left.d_{2}\right) \delta 165.49,164.3,164.24,160.86,160.09,159.68$, $158.40,158.12$, 156.35, 155.77, 155.41, 155.32, 150.14, 149.44, 149.37, 149.35, 149.23, 141.71, $141.50,141.43,137.16,137.11,136.78,136.10,134.96,132.85,132.84,126.54,125.27,122.69$, $122.59,121.31,121.28,121.07,120.44,119.70,119.34,116.96,116.89,107.16,66.10,65.74$, 53.26, 53.18, 37.83, 31.94, 31.91, 31.74, 31.64, 31.53, 31.00, 29.711, 29.63, 29.48, 29.49, 29.47, $29.37,29.34,29.31,29.28,28.63,26.43,26.09,24.49,22.70,22.69,22.59,13.90,13.89,13.83$.

DEPT $135{ }^{13} \mathrm{C}$ NMR (101 MHz, Dichloromethane- $\left.d_{2}\right) \delta=C H-:$ 155.41, 149.44, 149.37, 149.35, 149.23, 136.10, 126.54, 125.27, 122.69, 122.59, 121.31, 121.28, 121.07, 120.44, 119.34, 116.96, $116.89,107.16$; $-\mathrm{CH}_{2^{-}}:$66.10, 65.74, 37.83, 31.94, 31.91, 31.74, 31.64, 31.53, 31.00, 29.711, $29.63,29.48,29.49,29.47,29.37,29.34,29.31,29.28,28.63,26.43,26.09,24.49,22.70,22.69$, $22.59 ;-\mathrm{CH}_{3}: 53.26,53.18,13.90,13.89,13.83$.

HRMS (ESI): $\mathrm{m} / \mathrm{z}=1909.7163[\mathrm{M}]^{+}$, (calculated for $\left[\mathrm{RuC}_{112} \mathrm{H}_{155} \mathrm{~N}_{6} \mathrm{O}_{6} \mathrm{~S}_{4}\right]^{+}: \mathrm{m} / \mathrm{z}=1909.9963$ ).

\section{$\left[\mathrm{Ru}\left(\mathrm{C}^{\wedge} \mathrm{N}\right)(31)\left(\mathrm{bpy}\left(\mathrm{CO}_{2} \mathrm{H}\right)_{2}\right)\right]\left(\mathrm{PF}_{6}\right)(\mathrm{SA}-285)$}

${ }^{1} H$ NMR (400 MHz, Dichloromethane- $\left.d_{2}\right) \delta 12.24(\mathrm{~s}, 1 \mathrm{H}), 9.84(\mathrm{~s}, 1 \mathrm{H}), 9.72(\mathrm{~s}, 1 \mathrm{H}), 8.60(\mathrm{~d}, J=$ $8.3 \mathrm{~Hz}, 1 \mathrm{H}), 8.28(\mathrm{~d}, J=6.2 \mathrm{~Hz}, 3 \mathrm{H}), 7.98-7.92(\mathrm{~m}, 3 \mathrm{H}), 7.73(\mathrm{~d}, J=5.9 \mathrm{~Hz}, 1 \mathrm{H}), 7.59-7.49$ $(\mathrm{m}, 4 \mathrm{H}), 7.45(\mathrm{~d}, J=6.2 \mathrm{~Hz}, 1 \mathrm{H}), 7.41(\mathrm{dd}, J=5.8,1.6 \mathrm{~Hz}, 1 \mathrm{H}), 7.30(\mathrm{dd}, J=6.2,1.9 \mathrm{~Hz}, 1 \mathrm{H})$, $7.26-7.22(\mathrm{~m}, 1 \mathrm{H}), 6.71(\mathrm{~d}, J=4.1 \mathrm{~Hz}, 3 \mathrm{H}), 5.64(\mathrm{~s}, 1 \mathrm{H}), 4.45(\mathrm{t}, J=6.7 \mathrm{~Hz}, 2 \mathrm{H}), 4.20-4.06$ $(\mathrm{m}, 2 \mathrm{H}), 2.87(\mathrm{q}, J=4.8 \mathrm{~Hz}, 4 \mathrm{H}), 1.94-1.83(\mathrm{~m}, 8 \mathrm{H}), 1.78-1.48(\mathrm{~m}, 16 \mathrm{H}), 1.48-1.05(\mathrm{~m}$, $72 \mathrm{H}), 1.02-0.73(\mathrm{~m}, 24 \mathrm{H})$.

${ }^{13} \mathrm{C}$ NMR (101 MHz, Dichloromethane-d $\left.d_{2}\right) \delta 167.40,167.34,165.60,162.20,160.67,159.80$, $159.75,159.56,158.51,158.29,156.54,156.36,155.85,154.22,149.78,149.67,149.52,148.42$, $148.02,141.15,141.06,140.55,137.63,137.59$, 135.39, 132.96, 132.93, 130.91, 129.83, 128.71, $126.78,125.67,124.24,124.19,122.40,121.04,120.92,120.81,120.13,119.29,116.85,107.27$, $65.95,65.64,45.74,38.11,37.84,36.18,31.93,31.91,31.74,31.63,31.54,31.00,30.07,29.70$, $29.65,29.51,29.48,29.37,29.34,28.63,26.45,26.10,24.48,22.70,22.68,22.59,13.90,13.89$, $13.83,8.41$.

DEPT $135{ }^{13} \mathrm{C}$ NMR (101 MHz, Dichloromethane- $\left.d_{2}\right) \delta=C H-:$ 154.22, 149.52, 148.42, 148.02 , 135.39, 130.91, 129.83, 128.71, 126.78, 125.67, 124.24, 124.19, 122.40, 121.04, 120.92, 120.81, $120.13,116.85,106.27$; $-\mathrm{CH}_{2^{-}}: 65.95,65.64,45.74,38.11,37.84,36.18,31.93,31.91,31.74$, $31.63,31.54,31.00,30.07,29.70,29.65,29.51,29.48,29.37,29.34,28.63,26.45,26.10,24.48$, 22.70, 22.68, 22.59; $-\mathrm{CH}_{3}: 13.90,13.89,13.83,8.41$.

Below 1H NMR and 13C or 13C-DEPT-135 are brought. DEPT-135 NMR are preferred when high concentrations for the 13C NMR were not available. Note that for SA22 and SA25 NMRs 
for the non-hydrolyzed products are shown, since final products' amount were not enough to obtain NMR signals. 
$1 \mathrm{H}$ NMR of $\left[\mathrm{Ru}\left(\mathrm{C}^{\wedge} \mathrm{N}\right)(29)\left(\mathrm{bpy}\left(\mathrm{CO}_{2} \mathrm{Me}\right)_{2}\right)\right]\left(\mathrm{PF}_{6}\right)(\mathrm{SA}-20)$
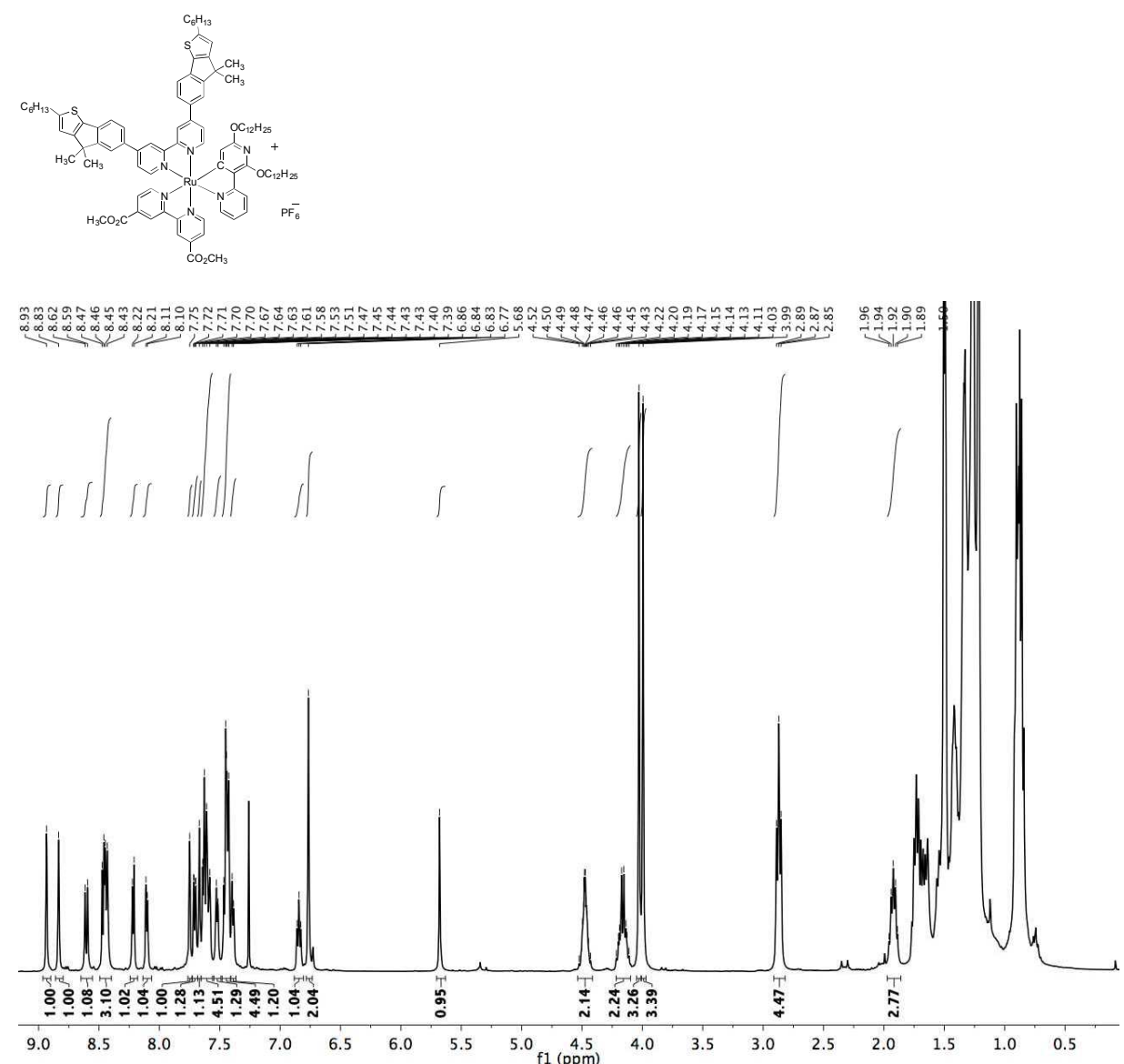

$1 \mathrm{H} N M R$ (aromatic region) of $\left[\mathrm{Ru}\left(\mathrm{C}^{\wedge} \mathrm{N}\right)(29)\left(\mathrm{bpy}\left(\mathrm{CO}_{2} \mathrm{Me}\right)_{2}\right)\right]\left(\mathrm{PF}_{6}\right)(\mathrm{SA}-20)$
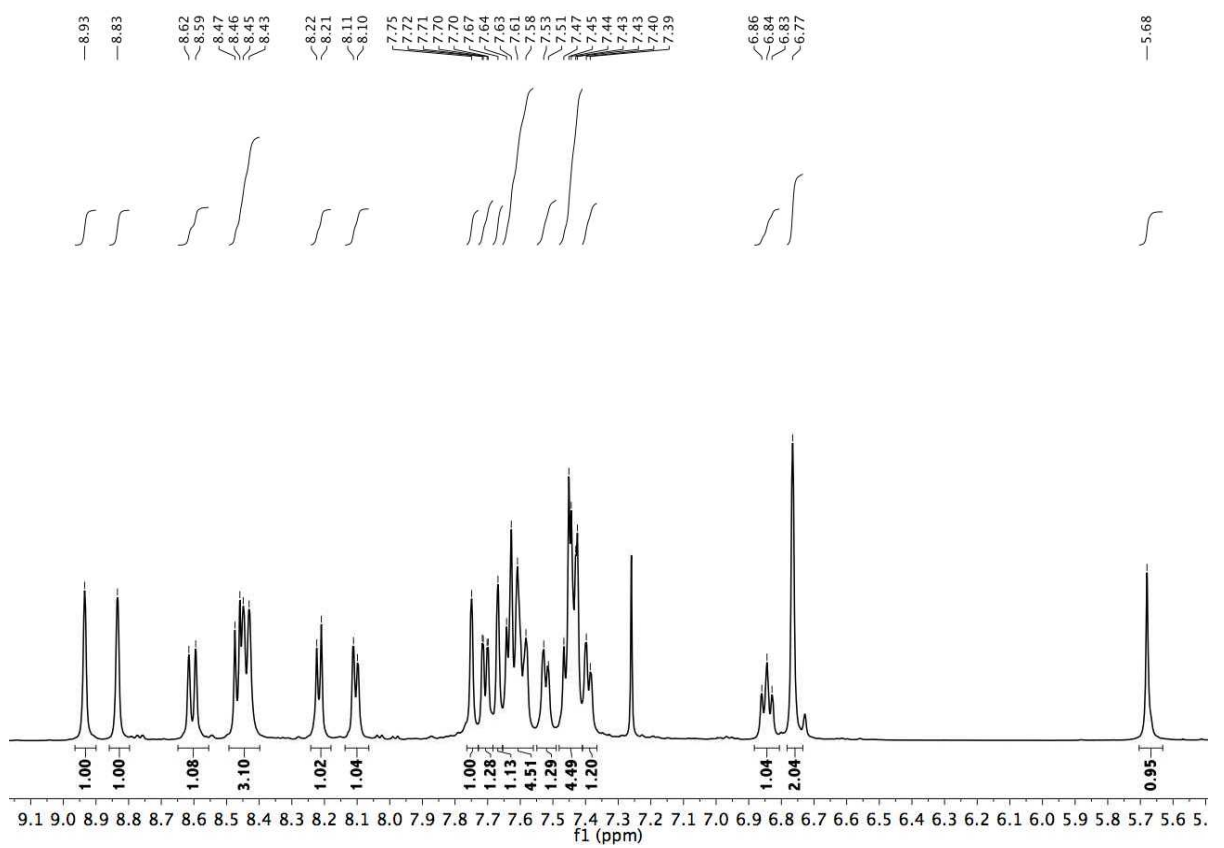
$1 \mathrm{H} N M R$ of $\left[\mathrm{Ru}\left(\mathrm{C}^{\wedge} \mathbf{N}\right)(30)\left(\mathrm{bpy}\left(\mathrm{CO}_{2} \mathrm{Me}_{2}\right)\right]\left(\mathbf{P F}_{6}\right)(\mathbf{S A - 2 3})\right.$. (Contains dimethyl-2,2'-bipyridine4,4'-dicarboxylate, which were filtered from the final dye after hydrolysis to acidic form.)
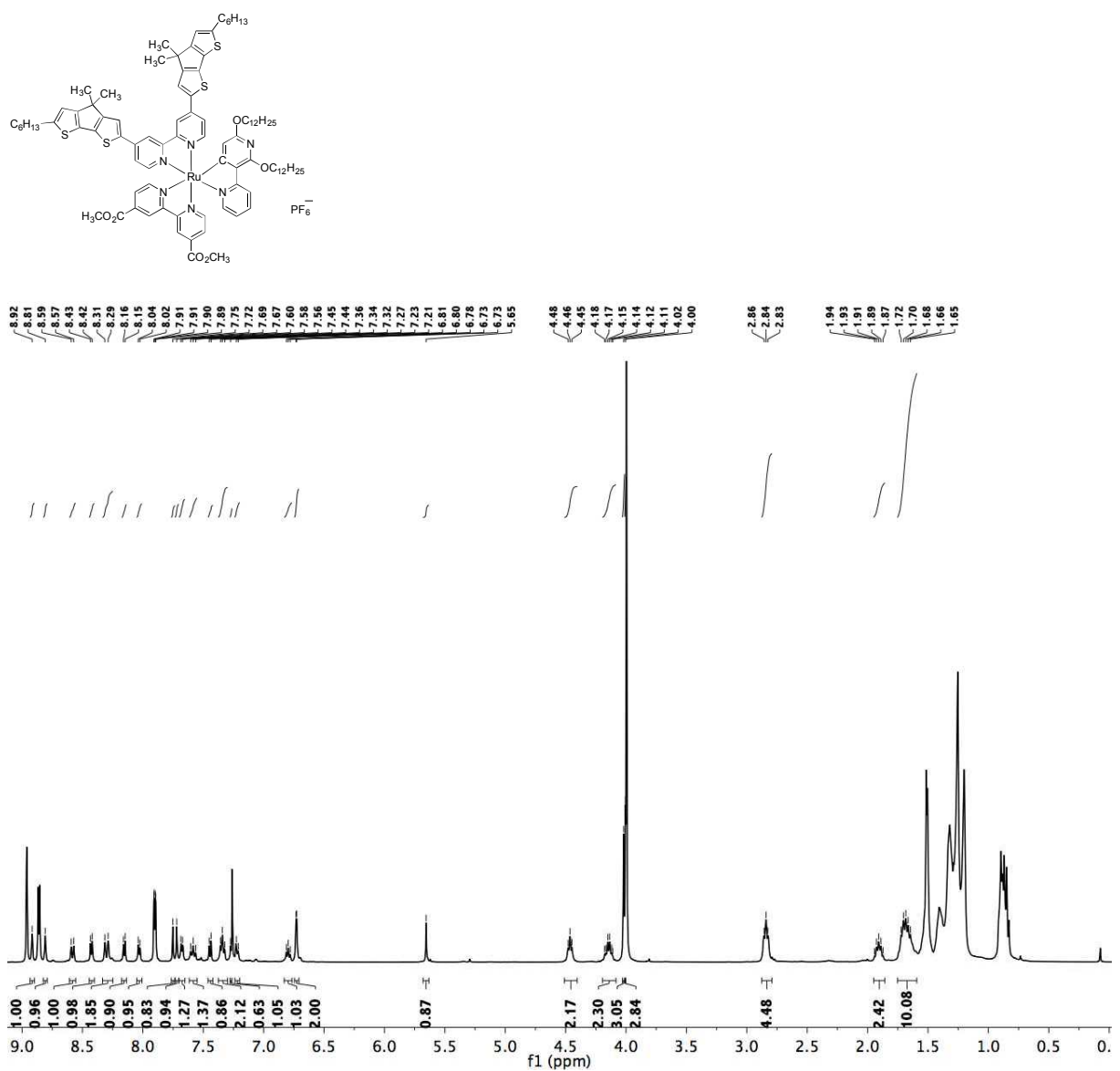

$1 \mathrm{H}$ NMR (aromatic region) of $\left[\mathrm{Ru}\left(\mathrm{C}^{\wedge} \mathrm{N}\right)(30)\left(\mathrm{bpy}\left(\mathrm{CO}_{2} \mathrm{Me}\right)_{2}\right)\right]\left(\mathrm{PF}_{6}\right)(\mathrm{SA}-23)$.

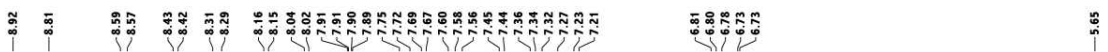

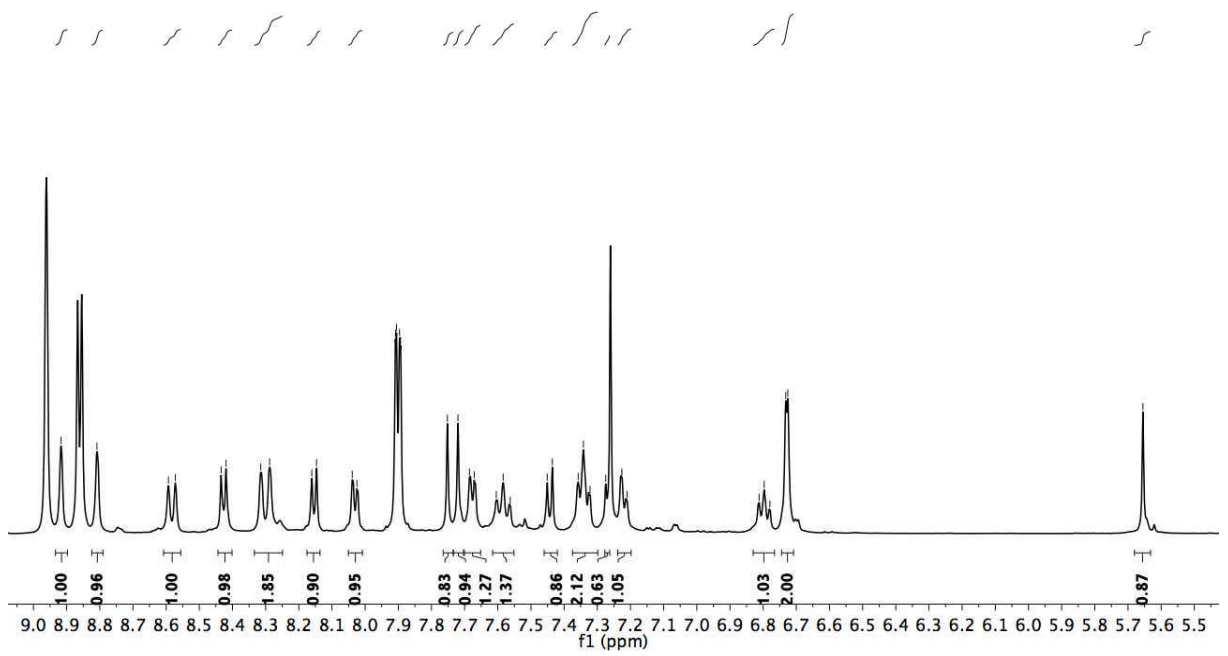


$1 \mathrm{H}$ NMR of $\left[\mathrm{Ru}\left(\mathrm{C}^{\wedge} \mathrm{N}\right)(32)\left(\mathrm{bpy}\left(\mathrm{CO}_{2} \mathrm{Me}\right)_{2}\right)\right]\left(\mathrm{PF}_{6}\right)(\mathrm{SA}-245)$
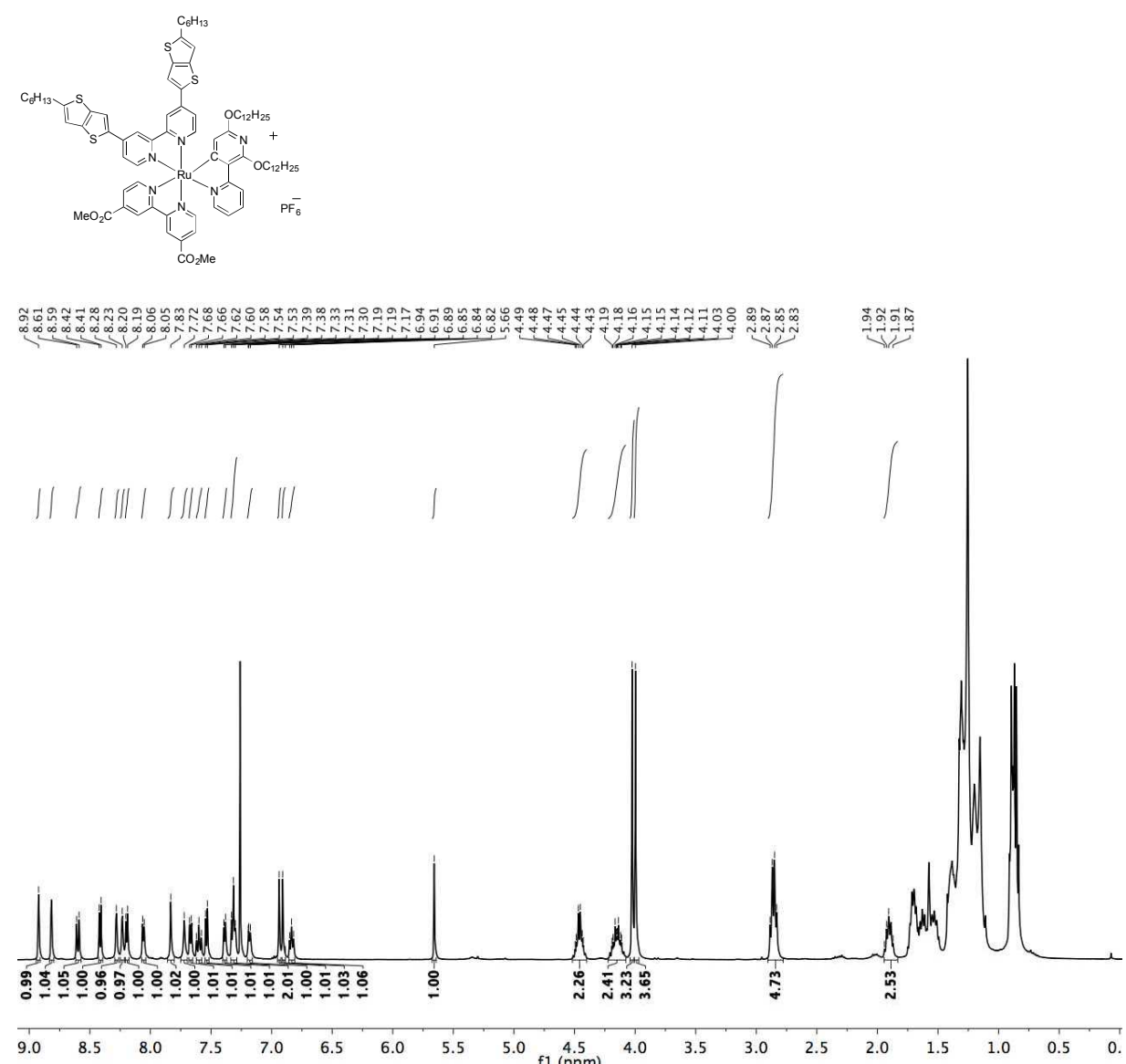

$1 \mathrm{H}$ NMR (aromatic region) of $\left[\mathrm{Ru}\left(\mathrm{C}^{\wedge} \mathrm{N}\right)(32)\left(\mathrm{bpy}\left(\mathrm{CO}_{2} \mathrm{Me}\right)_{2}\right)\right]\left(\mathrm{PF}_{6}\right)(\mathrm{SA}-245)$.

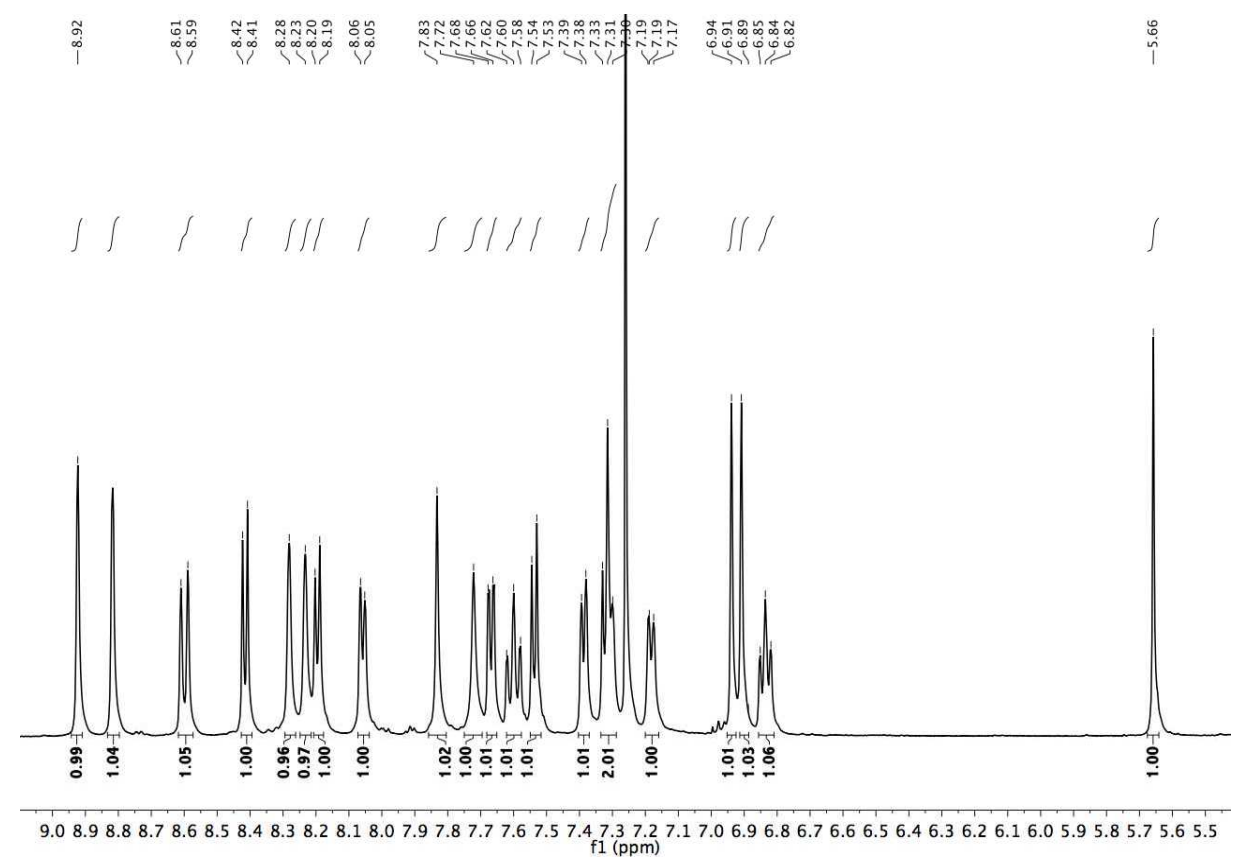


DEPT $135{ }^{13} \mathrm{C}$ NMR of $\left[\mathrm{Ru}\left(\mathrm{C}^{\wedge} \mathrm{N}\right)(32)\left(\mathrm{bpy}\left(\mathrm{CO}_{2} \mathrm{Me}\right)_{2}\right)\right]\left(\mathrm{PF}_{6}\right)(\mathrm{SA}-245)$

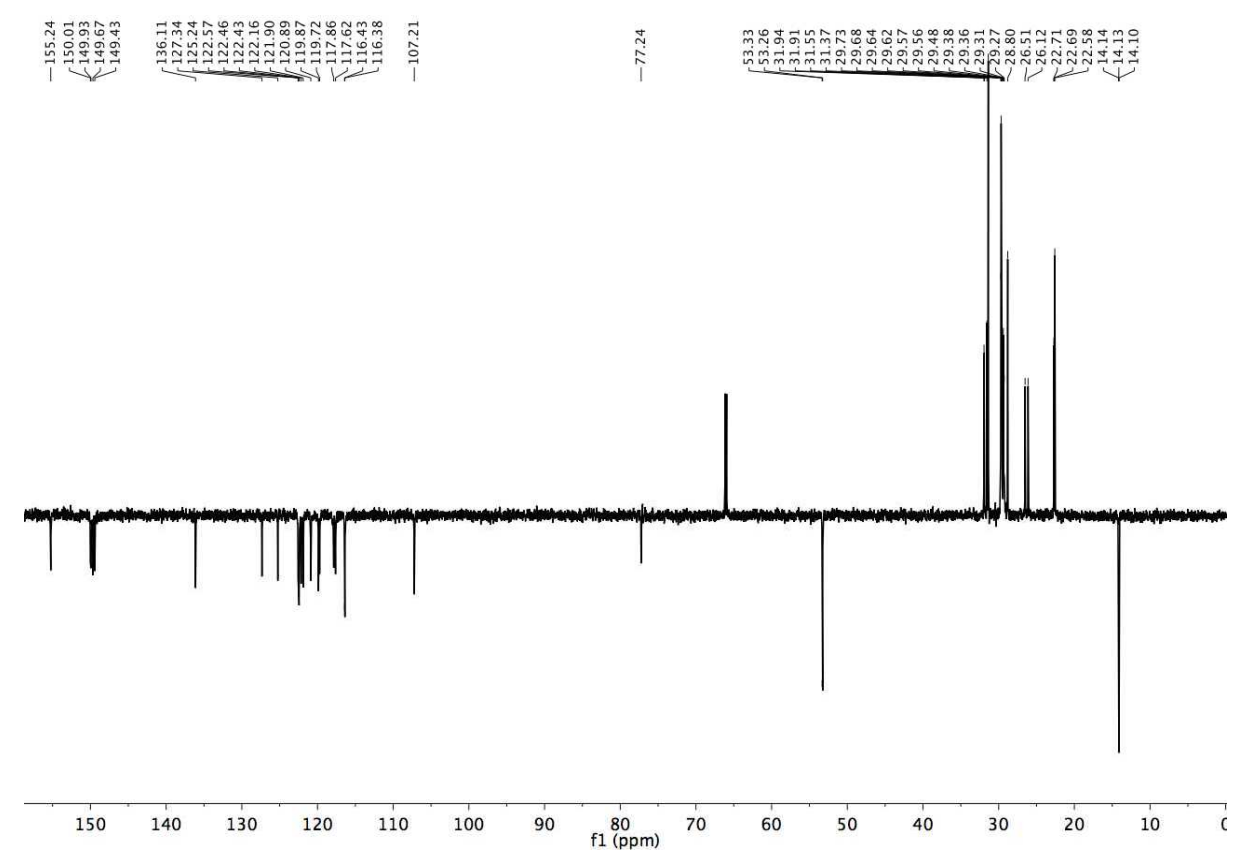

DEPT $135{ }^{13} \mathrm{C} N M R$ (aromatic region) of $\left[\mathrm{Ru}\left(\mathrm{C}^{\wedge} \mathrm{N}\right)(32)\left(\mathrm{bpy}\left(\mathrm{CO}_{2} \mathrm{Me}\right)_{2}\right)\right]\left(\mathrm{PF}_{6}\right)(\mathrm{SA}-245)$.
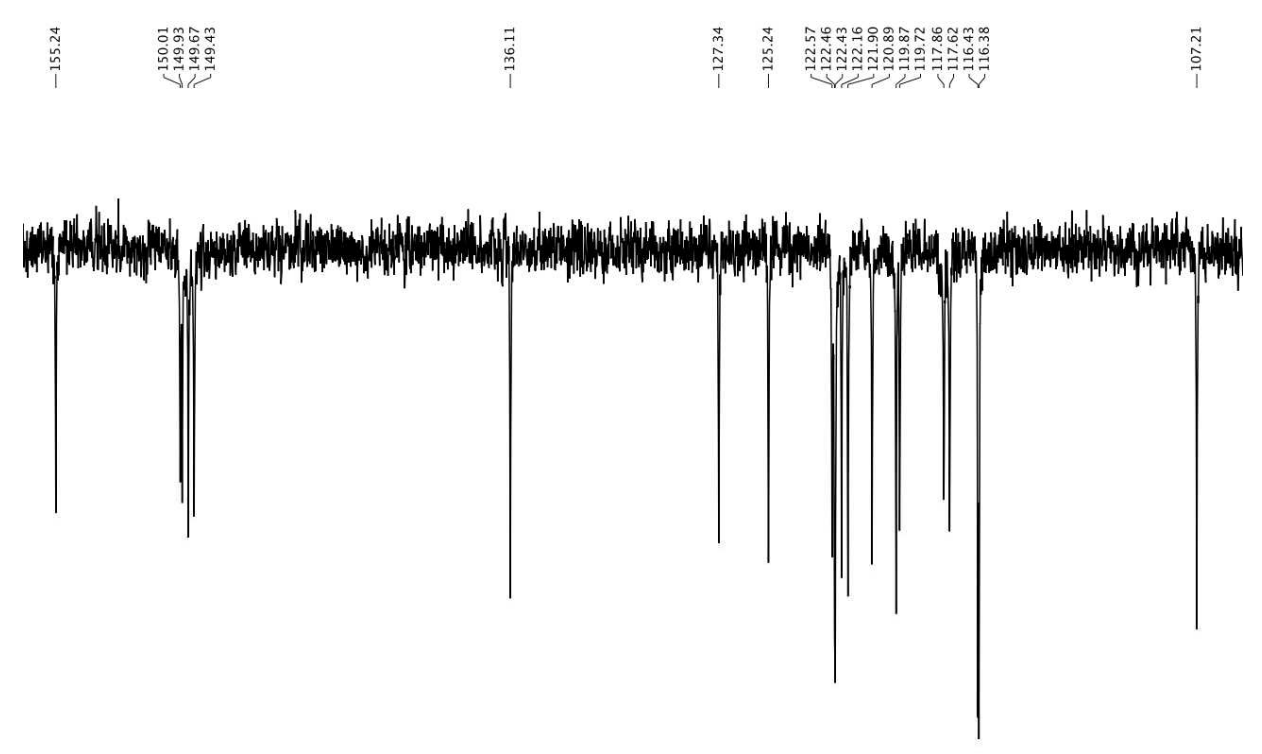

\begin{tabular}{lllllllllllllllllllllllllllllllll}
\hline 156 & 154 & 152 & 150 & 148 & 146 & 144 & 142 & 140 & 138 & 136 & 134 & $\begin{array}{l}132 \\
\mathrm{f} 1(\mathrm{ppm})\end{array}$ & 128 & 126 & 124 & 122 & 120 & 118 & 116 & 114 & 112 & 110 & 108 & 106
\end{tabular} 
$1 \mathrm{H}$ NMR of $\left[\mathrm{Ru}\left(\mathrm{C}^{\wedge} \mathrm{N}\right)(32)\left(\mathrm{bpy}\left(\mathrm{CO}_{2} \mathrm{H}\right)_{2}\right)\right]\left(\mathrm{PF}_{6}\right)(\mathrm{SA}-246)$.

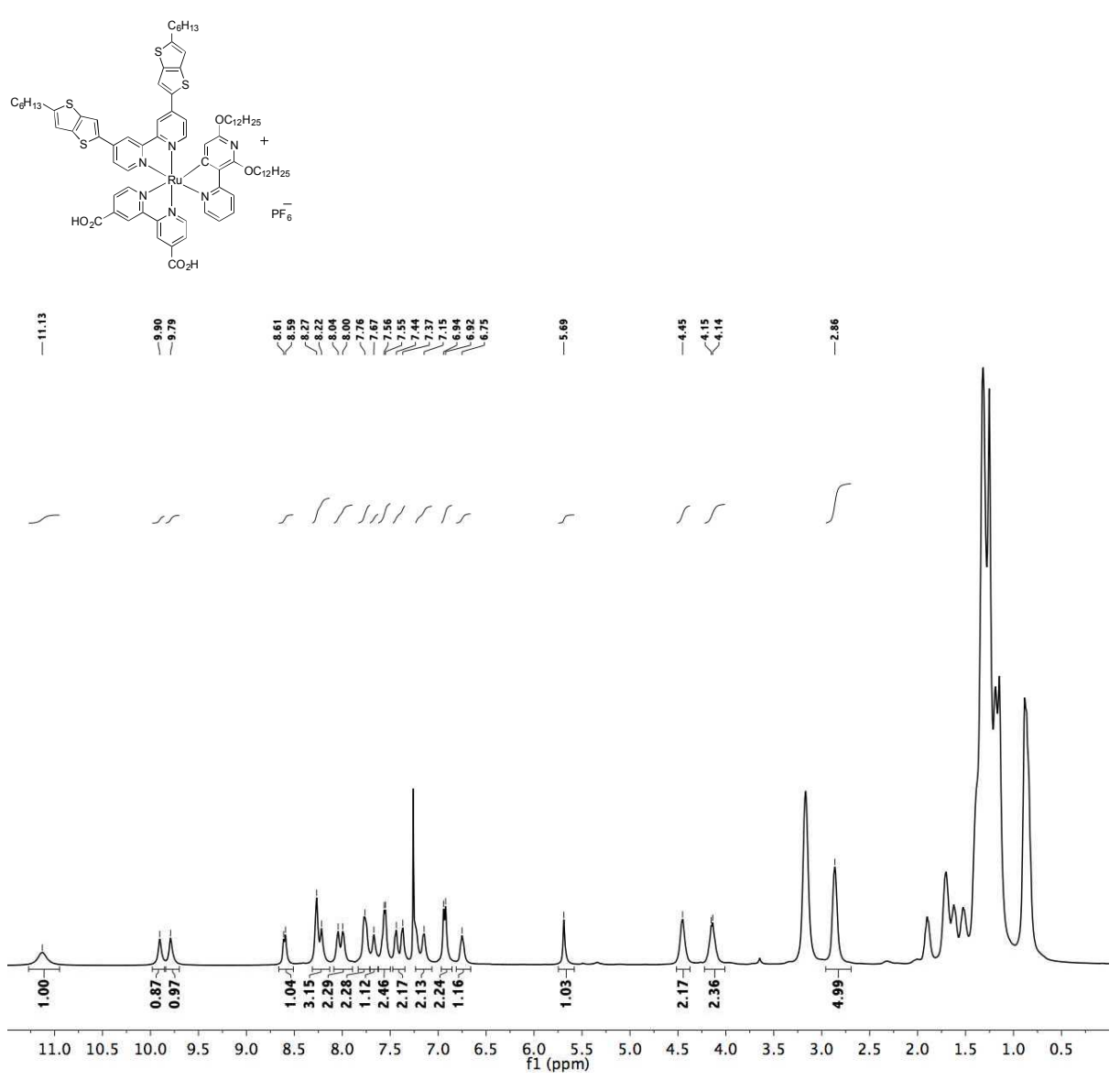

1H NMR (aromatic region) of $\left[\mathrm{Ru}\left(\mathrm{C}^{\wedge} \mathrm{N}\right)(32)\left(\mathrm{bpy}\left(\mathrm{CO}_{2} \mathrm{H}\right)_{2}\right)\right]\left(\mathrm{PF}_{6}\right)(\mathrm{SA}-246)$.
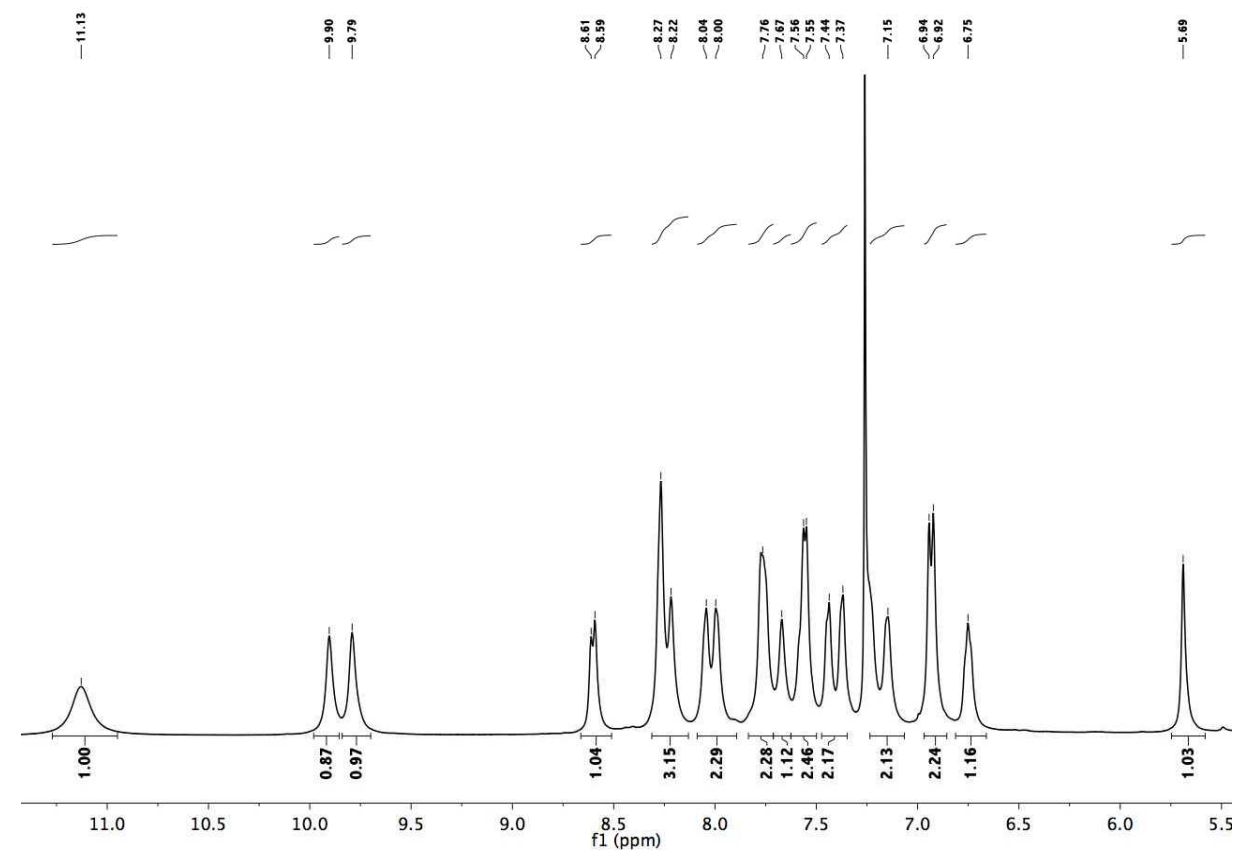
DEPT $135{ }^{13} \mathrm{C}$ NMR of $\left[\mathrm{Ru}\left(\mathrm{C}^{\wedge} \mathrm{N}\right)(32)\left(\mathrm{bpy}\left(\mathrm{CO}_{2} \mathrm{H}\right)_{2}\right)\right]\left(\mathrm{PF}_{6}\right)(\mathrm{SA}-246)$

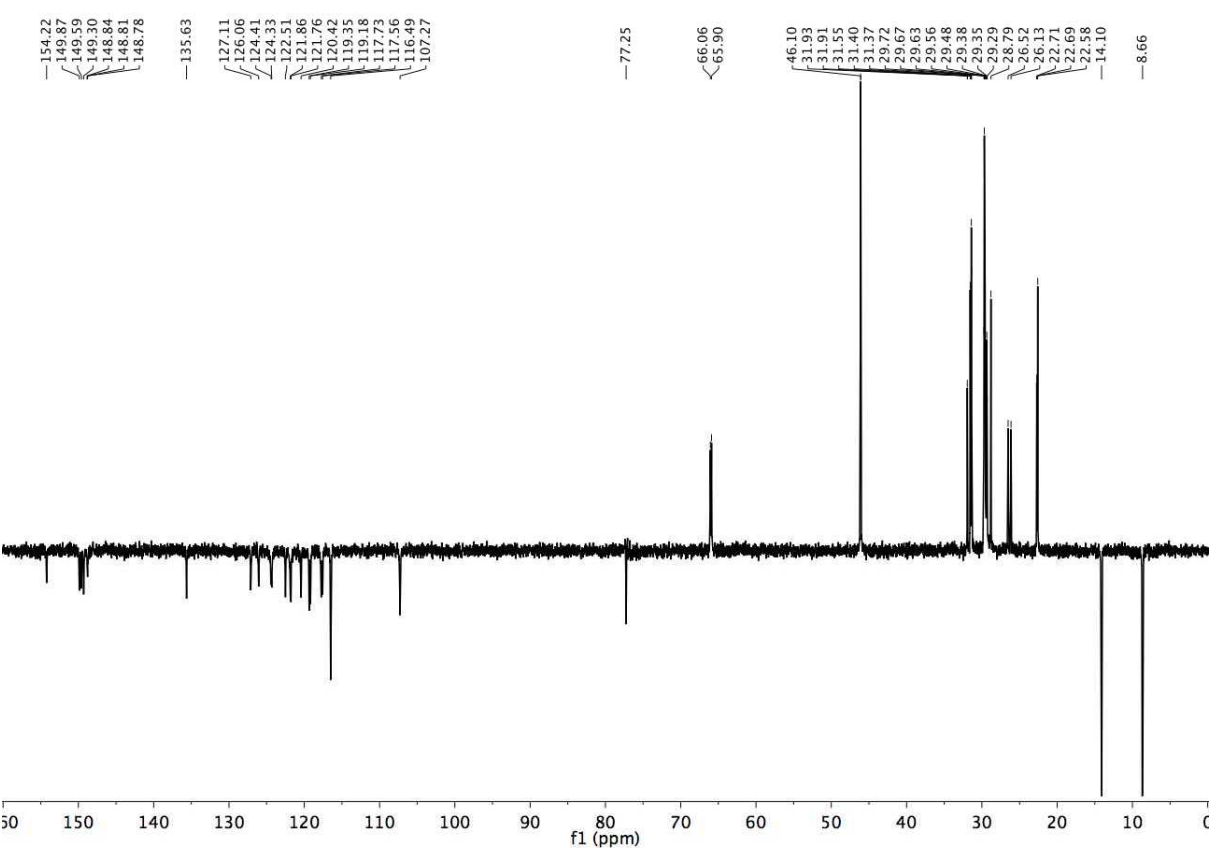

DEPT $135{ }^{13} \mathrm{C}$ NMR (aromatic region) of $\left[\mathrm{Ru}\left(\mathrm{C}^{\wedge} \mathrm{N}\right)(32)\left(\mathrm{bpy}\left(\mathrm{CO}_{2} \mathrm{H}\right)_{2}\right)\right]\left(\mathrm{PF}_{6}\right)(\mathrm{SA}-246)$.

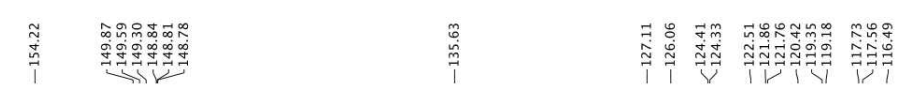

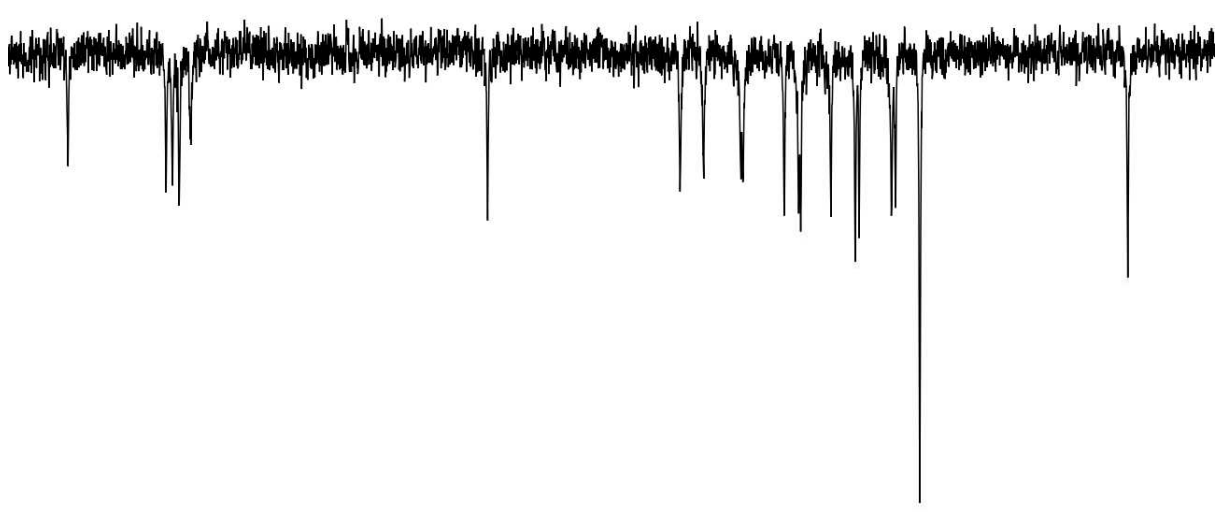

$\begin{array}{llllllllllllllllllllllllllllllll}156 & 154 & 152 & 150 & 148 & 146 & 144 & 142 & 140 & 138 & 136 & 134 & 132 & 130 & 128 & 126 & 124 & 122 & 120 & 118 & 116 & 114 & 112 & 110 & 108 & 106 & 104\end{array}$ 
1H NMR of $\left[\mathrm{Ru}\left(\mathrm{C}^{\wedge} \mathrm{N}\right)(34)\left(\mathrm{bpy}\left(\mathrm{CO}_{2} \mathrm{Me}\right)_{2}\right)\right]\left(\mathrm{PF}_{6}\right)(\mathrm{SA}-274)$.

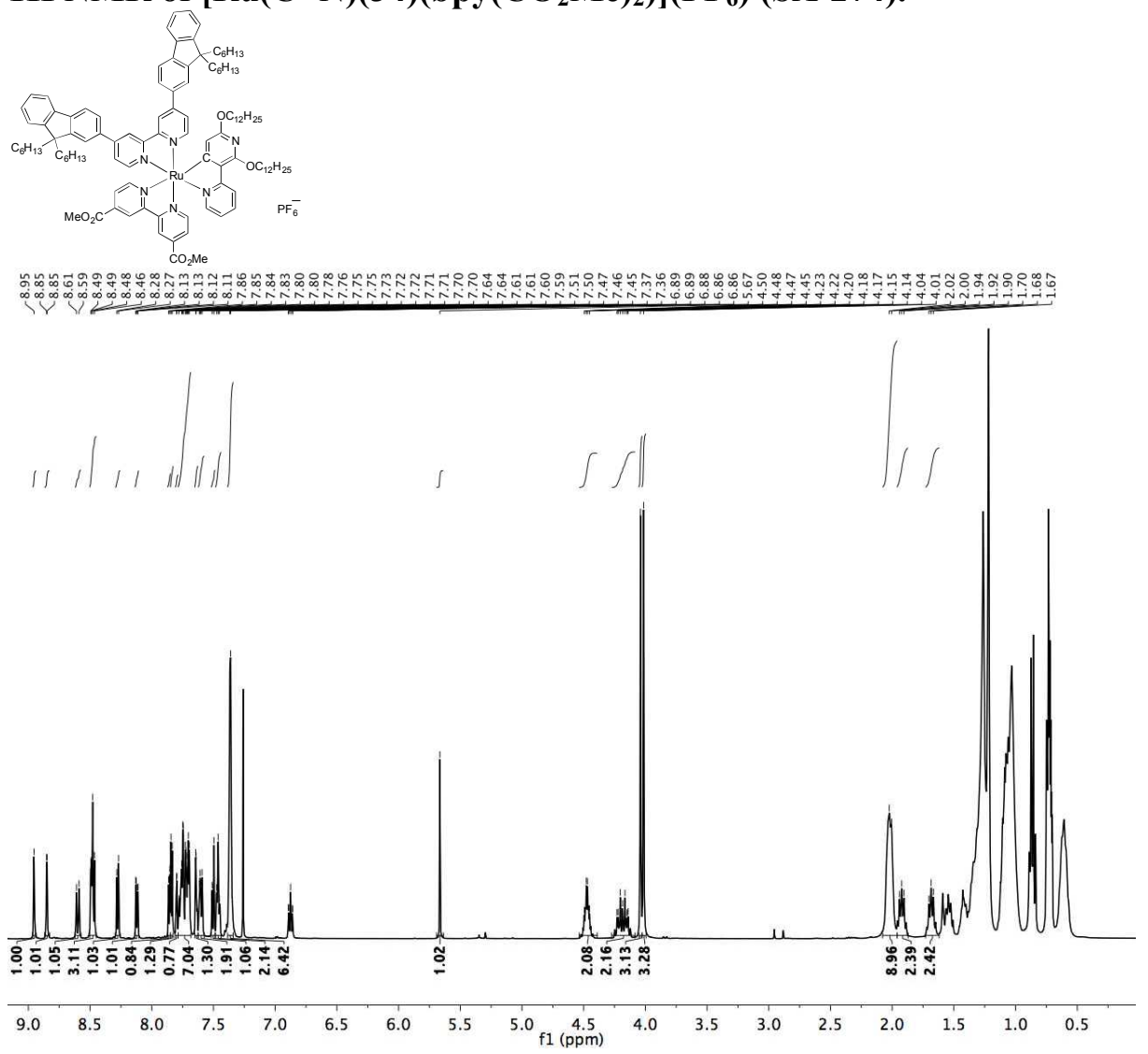

1H NMR (aromatic region) of $\left[\mathrm{Ru}\left(\mathrm{C}^{\wedge} \mathrm{N}\right)(34)\left(\mathrm{bpy}\left(\mathrm{CO}_{2} \mathrm{Me}\right)_{2}\right)\right]\left(\mathrm{PF}_{6}\right)(\mathrm{SA}-274)$.

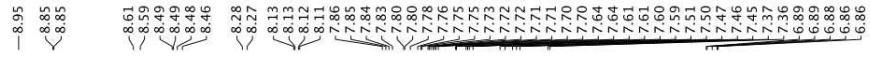

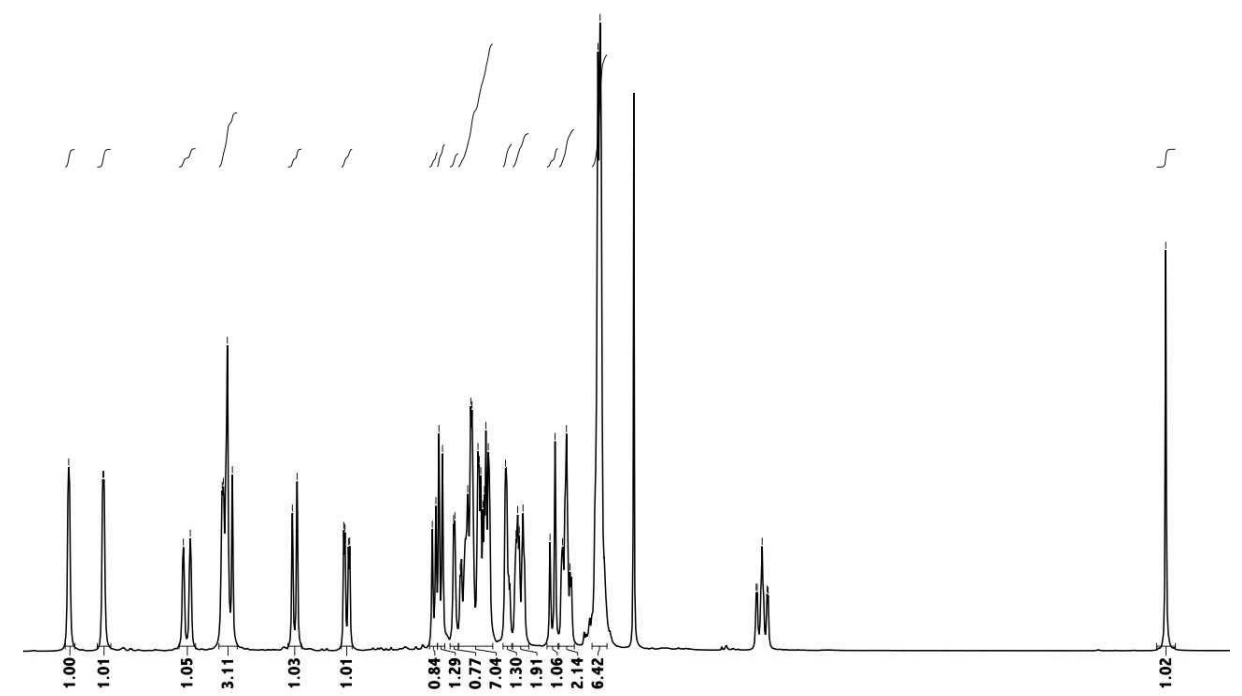

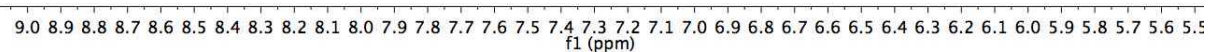


13C NMR of $\left[\mathrm{Ru}\left(\mathrm{C}^{\wedge} \mathrm{N}\right)(34)\left(\mathrm{bpy}\left(\mathrm{CO}_{2} \mathrm{Me}\right)_{2}\right)\right]\left(\mathrm{PF}_{6}\right)(\mathrm{SA}-274)$.

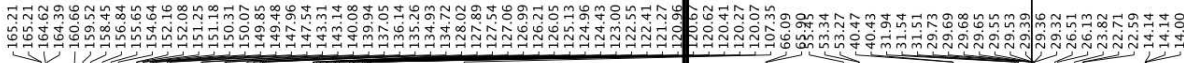

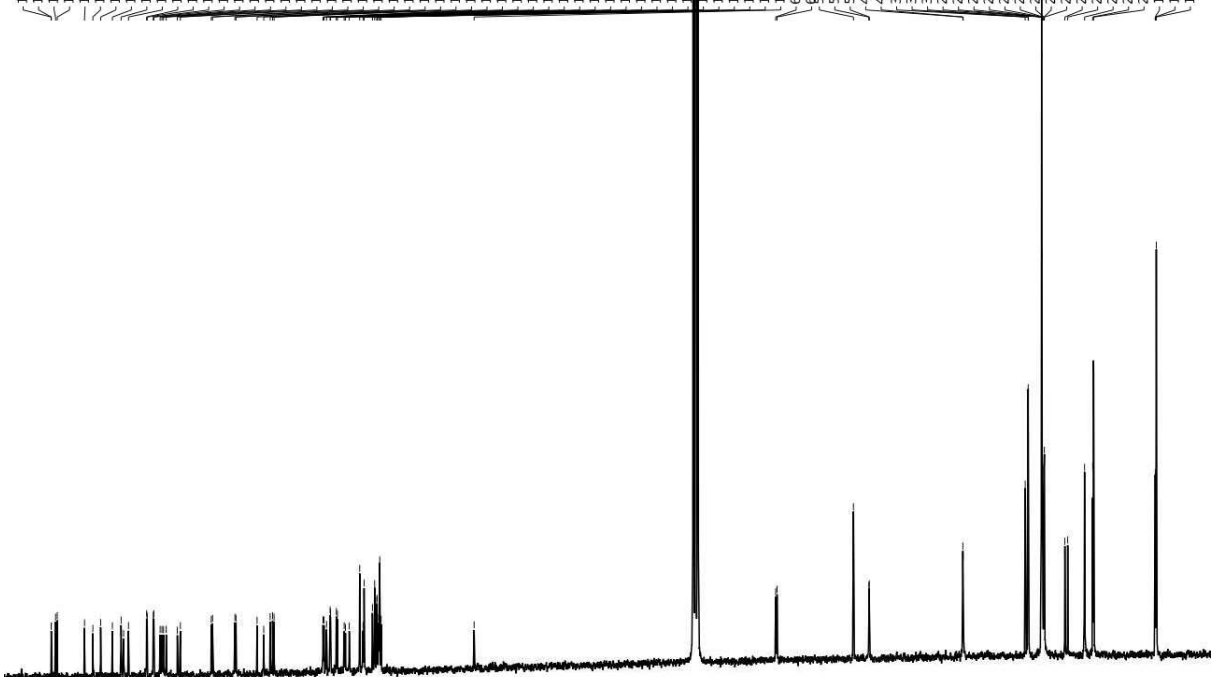

$\begin{array}{lllllllllllllllll}170 & 160 & 150 & 140 & 130 & 120 & 110 & 100 & 90 & 10 & 70 & 60 & 50 & 40 & 30 & 20 & 10\end{array}$

13C NMR (aromatic region) of $\left[\mathrm{Ru}\left(\mathrm{C}^{\wedge} \mathrm{N}\right)(34)\left(\mathrm{bpy}\left(\mathrm{CO}_{2} \mathrm{Me}\right)_{2}\right)\right]\left(\mathrm{PF}_{6}\right)(\mathrm{SA}-274)$.

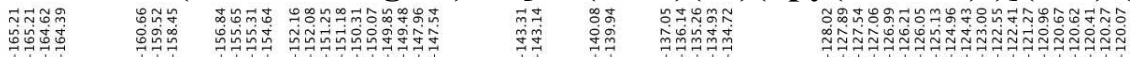

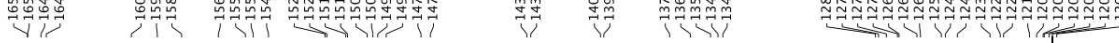

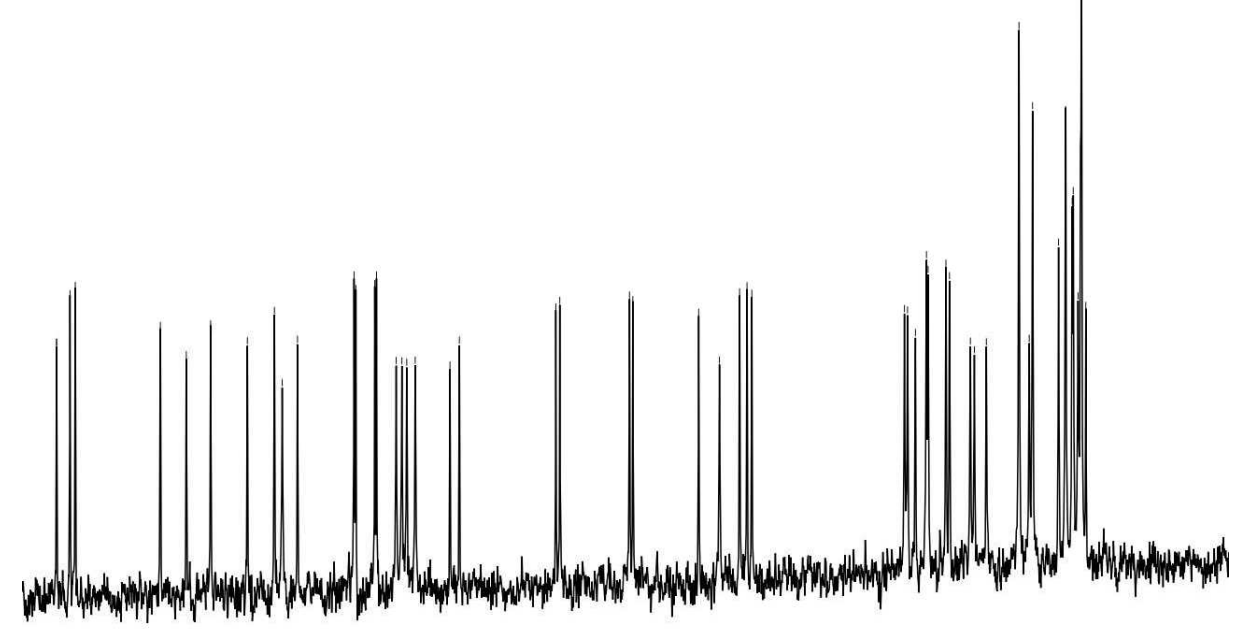

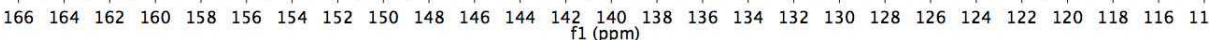


DEPT $135{ }^{13} \mathrm{C}$ NMR of $\left[\mathrm{Ru}\left(\mathrm{C}^{\wedge} \mathrm{N}\right)(34)\left(\mathrm{bpy}\left(\mathrm{CO}_{2} \mathrm{Me}\right)_{2}\right)\right]\left(\mathrm{PF}_{6}\right)(\mathrm{SA}-274)$.

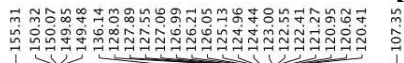

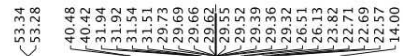

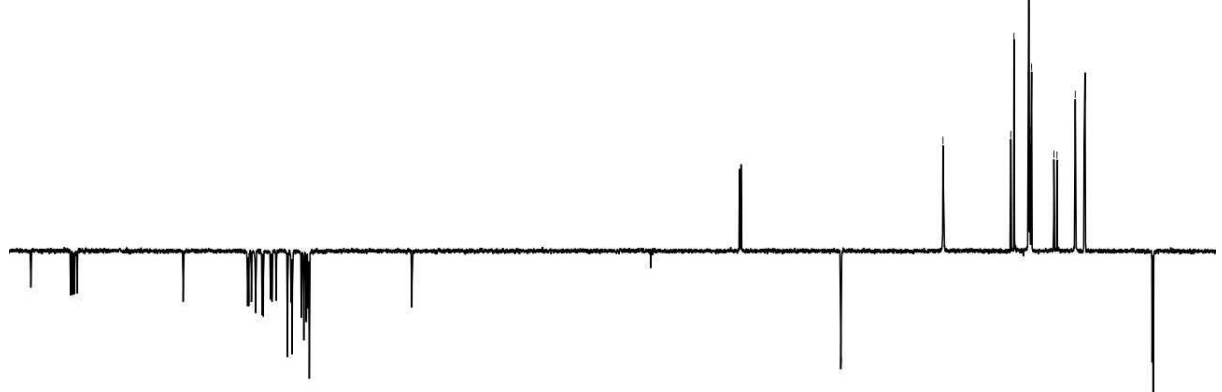

$\begin{array}{llllllllllllllllllllllllllllllllll}155 & 150 & 145 & 140 & 135 & 130 & 125 & 120 & 115 & 110 & 105 & 100 & 95 & 90 & 85 & 80 & 75 & 70 & 65 & 60 & 55 & 50 & 45 & 40 & 35 & 30 & 25 & 20 & 15 & 10\end{array}$

DEPT $135{ }^{13} \mathrm{C} N M R$ (aromatic region) of $\left[\mathrm{Ru}\left(\mathrm{C}^{\wedge} \mathrm{N}\right)(34)\left(\mathrm{bpy}\left(\mathrm{CO}_{2} \mathrm{Me}\right)_{2}\right)\right]\left(\mathrm{PF}_{6}\right)(\mathrm{SA}-274)$.

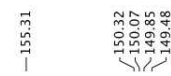

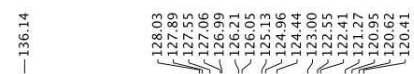

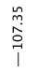

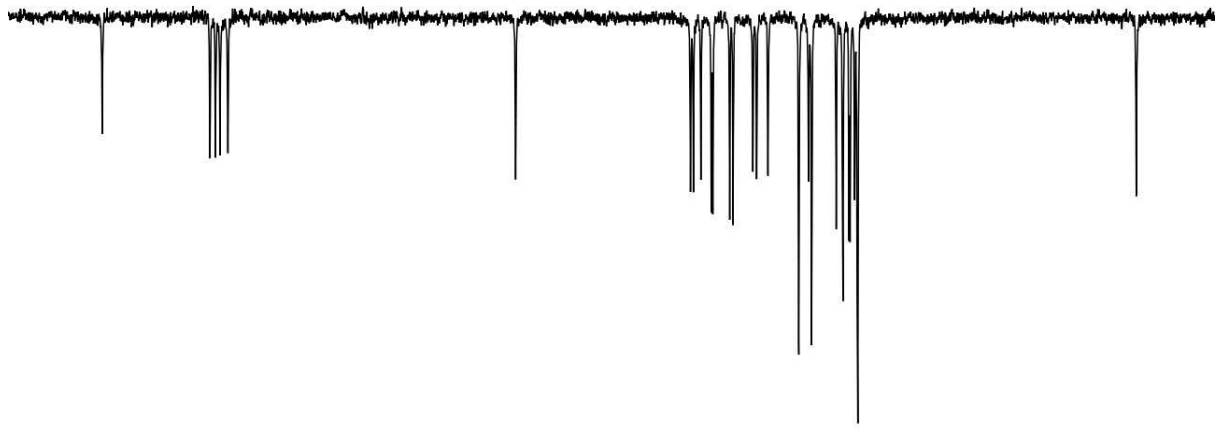

$\begin{array}{lllllllllllllllllllllllllllll}158 & 156 & 154 & 152 & 150 & 148 & 146 & 144 & 142 & 140 & 138 & 136 & 134 & 132 & 130 & 128 & 126 & 124 & 122 & 120 & 118 & 116 & 114 & 112 & 110 & 108 & 106 & 10\end{array}$ 


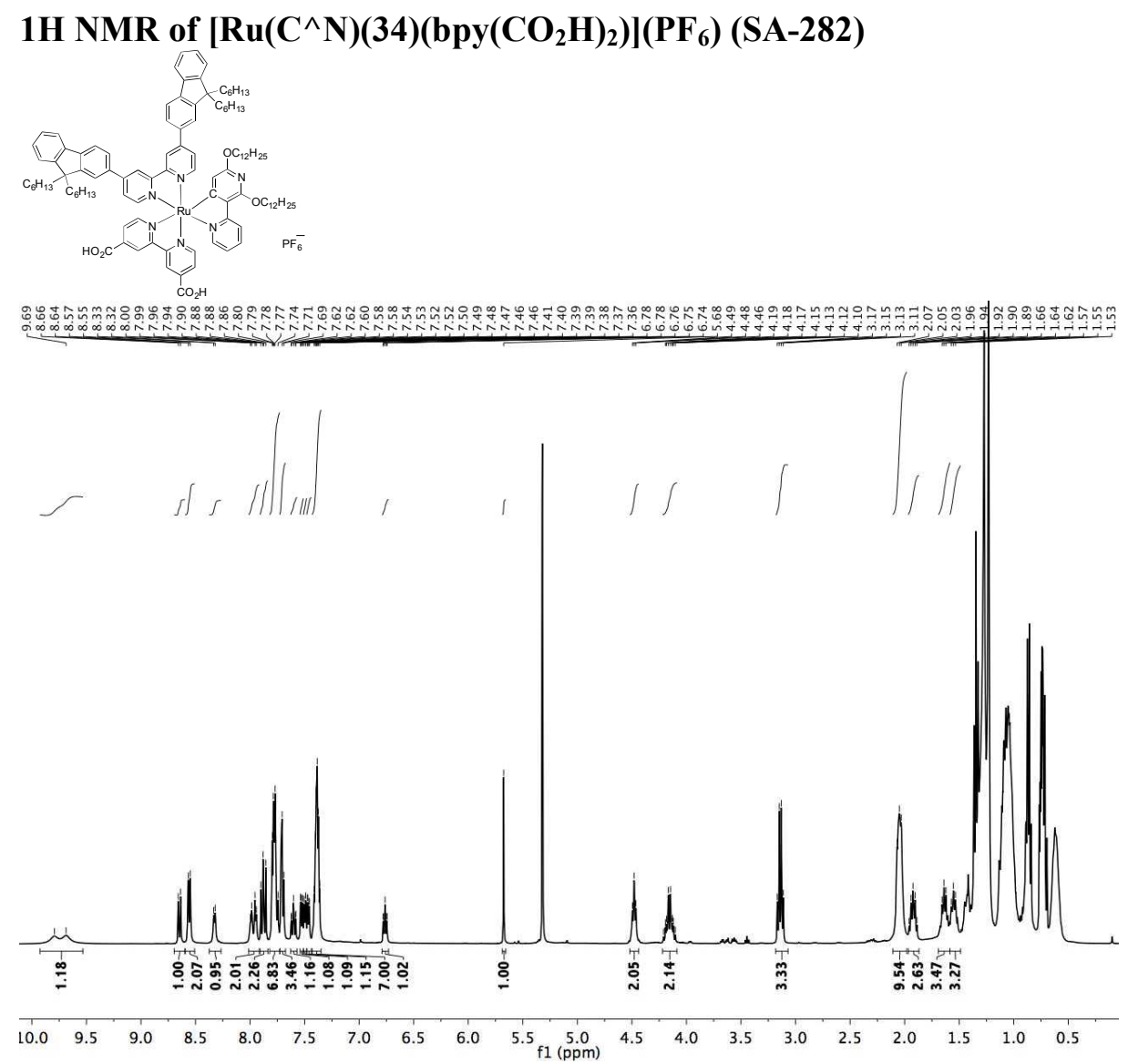

$1 \mathrm{H}$ NMR (aromatic region) of $\left[\mathrm{Ru}\left(\mathrm{C}^{\wedge} \mathrm{N}\right)(34)\left(\mathrm{bpy}\left(\mathrm{CO}_{2} \mathrm{H}\right)_{2}\right)\right]\left(\mathrm{PF}_{6}\right)(\mathrm{SA}-282)$

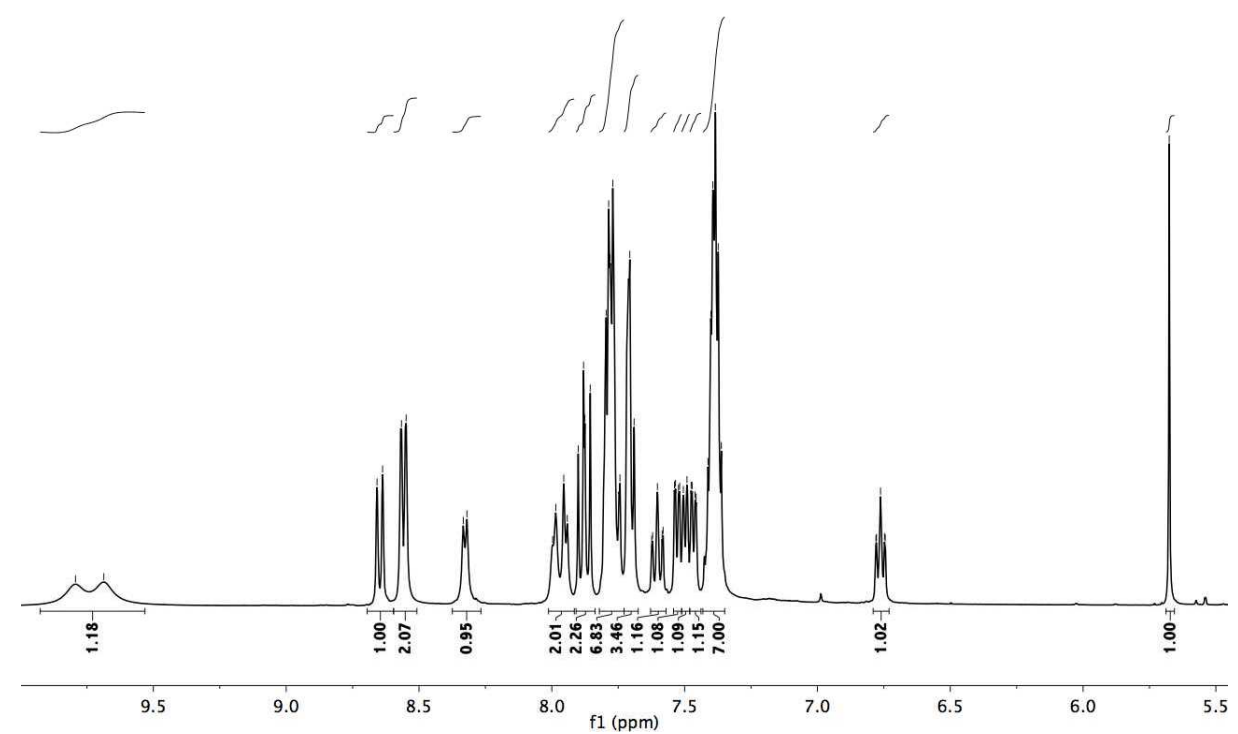




\section{C NMR of $\left[\mathrm{Ru}\left(\mathrm{C}^{\wedge} \mathrm{N}\right)(34)\left(\mathrm{bpy}\left(\mathrm{CO}_{2} \mathrm{H}\right)_{2}\right)\right]\left(\mathrm{PF}_{6}\right)(\mathrm{SA}-282)$}

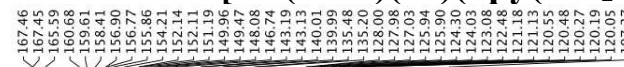

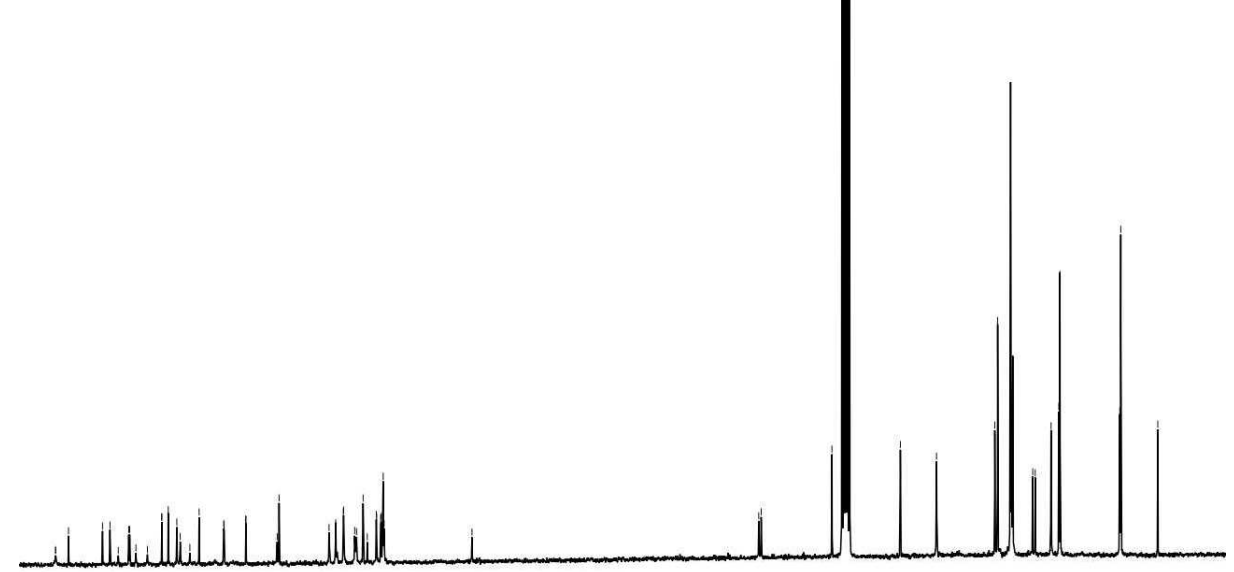

\begin{tabular}{lllllllllllllllll}
\hline 170 & 160 & 150 & 140 & 130 & 120 & 110 & 100 & $\substack{1 \\
\mathrm{f} 1(\mathrm{ppm})}$ & 70 & 60 & 50 & 40 & 30 & 20 & 10 & 0
\end{tabular}

13C NMR (aromatic region) of $\left[\mathrm{Ru}\left(\mathrm{C}^{\wedge} \mathrm{N}\right)(34)\left(\mathrm{bpy}\left(\mathrm{CO}_{2} \mathrm{H}\right)_{2}\right)\right]\left(\mathrm{PF}_{6}\right)(\mathrm{SA}-282)$

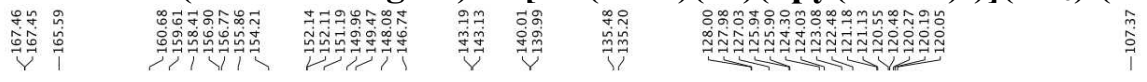

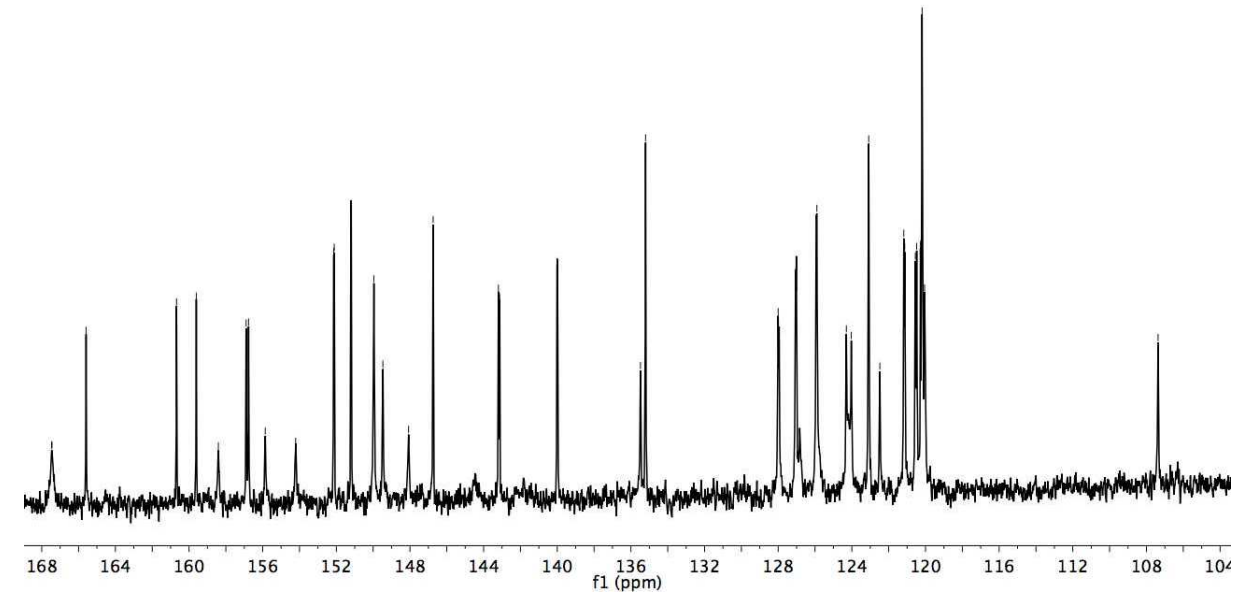


DEPT $135{ }^{13} \mathrm{C} N M R$ of $\left[\mathrm{Ru}\left(\mathrm{C}^{\wedge} \mathrm{N}\right)(34)\left(\mathrm{bpy}\left(\mathrm{CO}_{2} \mathrm{H}\right)_{2}\right)\right]\left(\mathrm{PF}_{6}\right)(\mathrm{SA}-282)$.

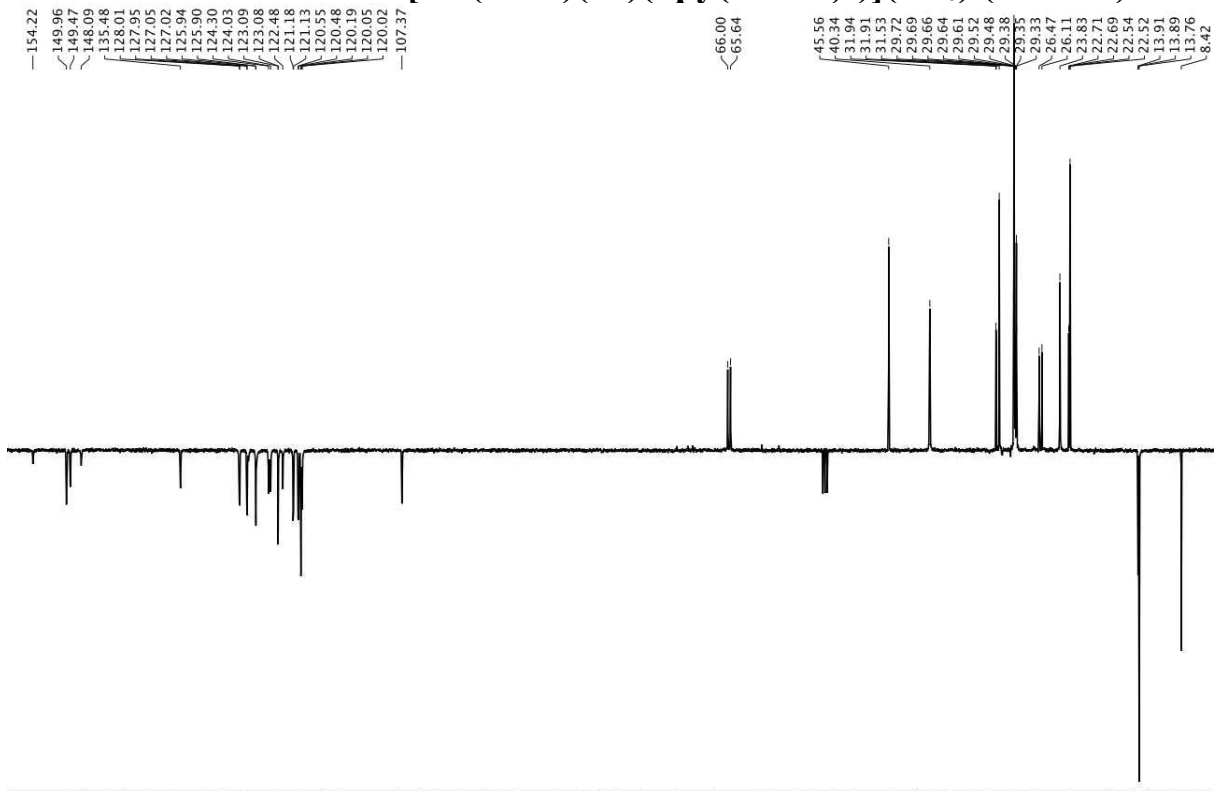

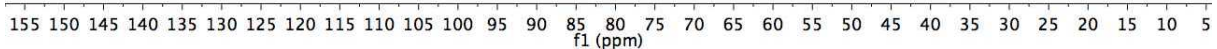

DEPT $135{ }^{13} \mathrm{C} N M R$ (aromatic region) of $\left[\mathrm{Ru}\left(\mathrm{C}^{\wedge} \mathrm{N}\right)(34)\left(\mathrm{bpy}\left(\mathrm{CO}_{2} \mathrm{H}\right)_{2}\right)\right]\left(\mathrm{PF}_{6}\right)(\mathrm{SA}-282)$.

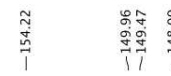

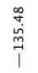

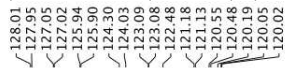

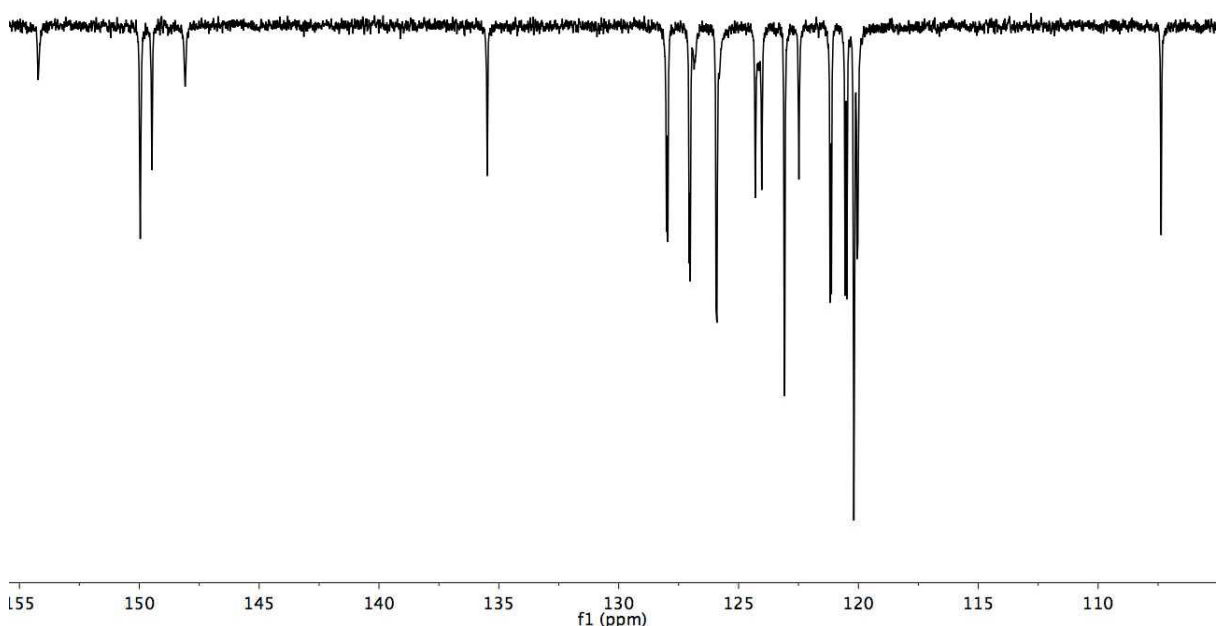




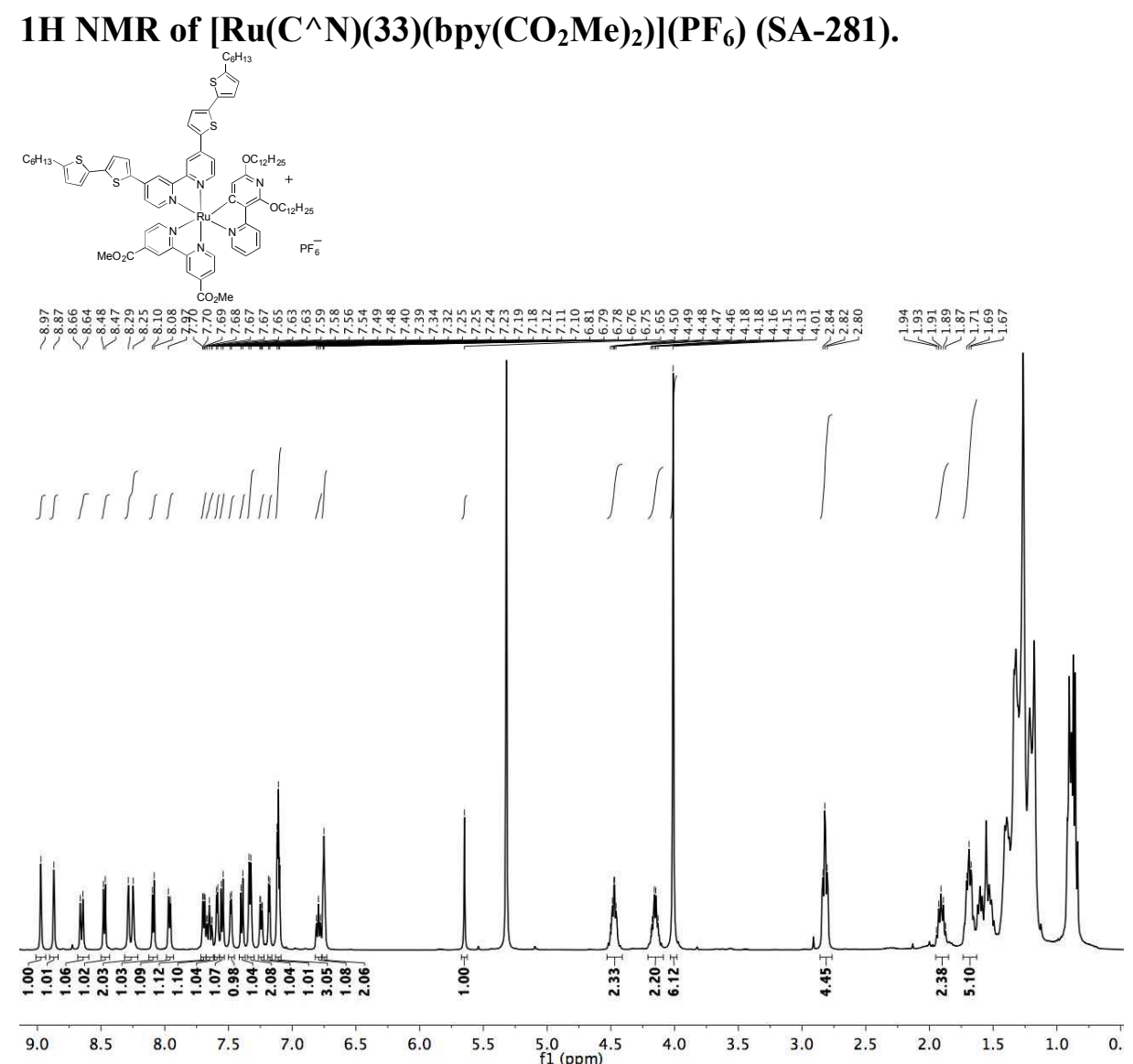

1H NMR (aromatic region) of $\left[\mathrm{Ru}\left(\mathrm{C}^{\wedge} \mathrm{N}\right)(33)\left(\mathrm{bpy}\left(\mathrm{CO}_{2} \mathrm{Me}\right)_{2}\right)\right]\left(\mathrm{PF}_{6}\right)(\mathrm{SA}-281)$.

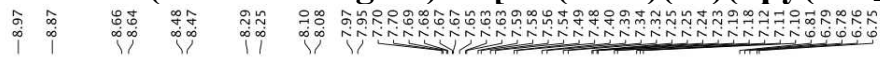

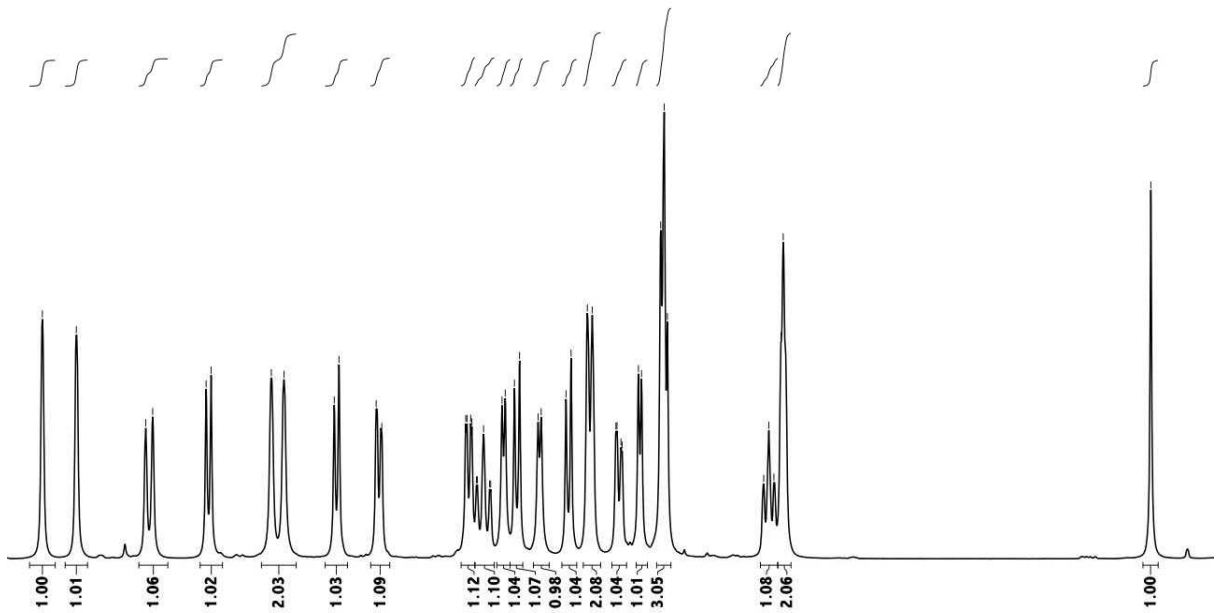

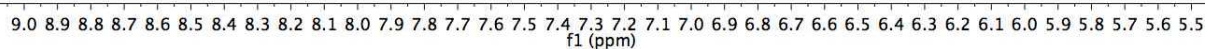


13C NMR of $\left[\mathrm{Ru}\left(\mathrm{C}^{\wedge} \mathrm{N}\right)(33)\left(\mathrm{bpy}\left(\mathrm{CO}_{2} \mathrm{Me}\right)_{2}\right)\right]\left(\mathrm{PF}_{6}\right)(\mathrm{SA}-281)$.

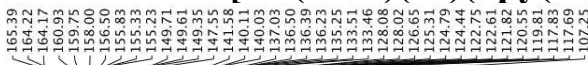

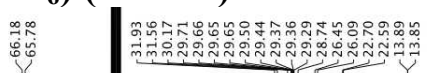
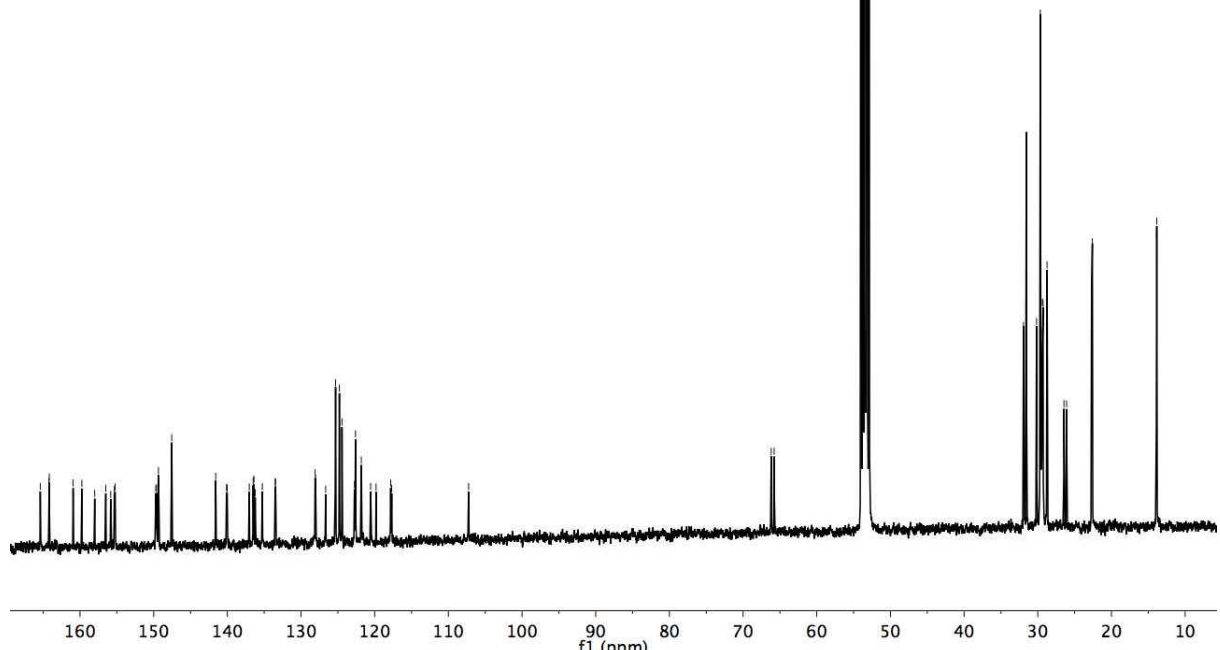

13C NMR (aromatic region) of $\left[\mathrm{Ru}\left(\mathrm{C}^{\wedge} \mathrm{N}\right)(33)\left(\mathrm{bpy}\left(\mathrm{CO}_{2} \mathrm{Me}\right)_{2}\right)\right]\left(\mathrm{PF}_{6}\right)(\mathrm{SA}-281)$.

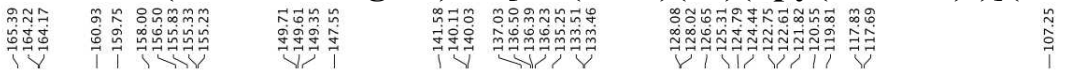

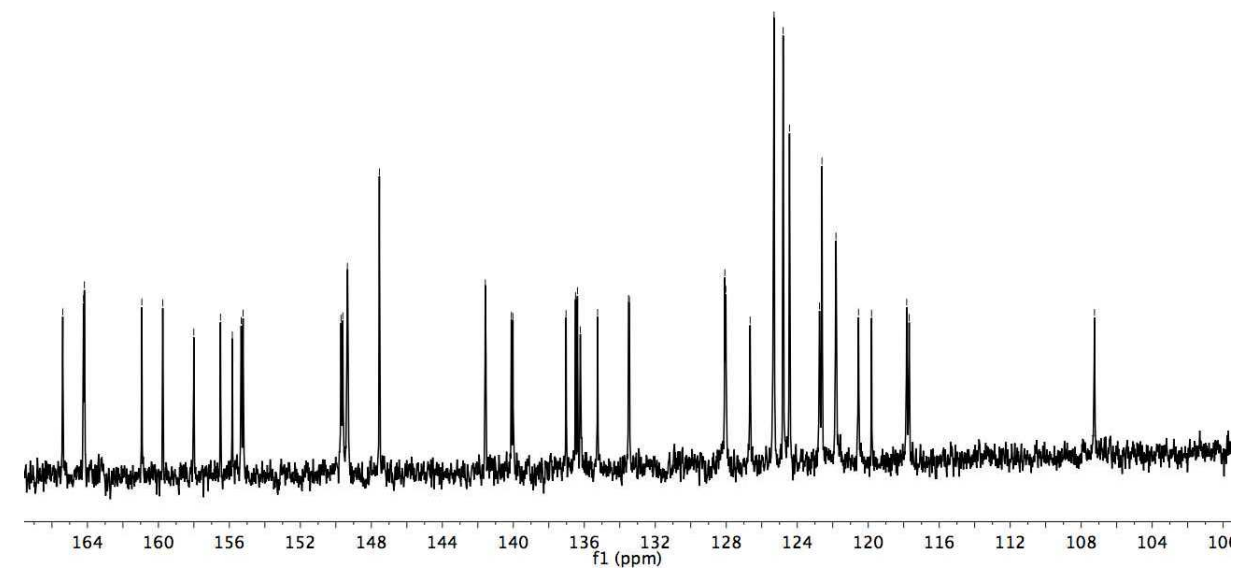




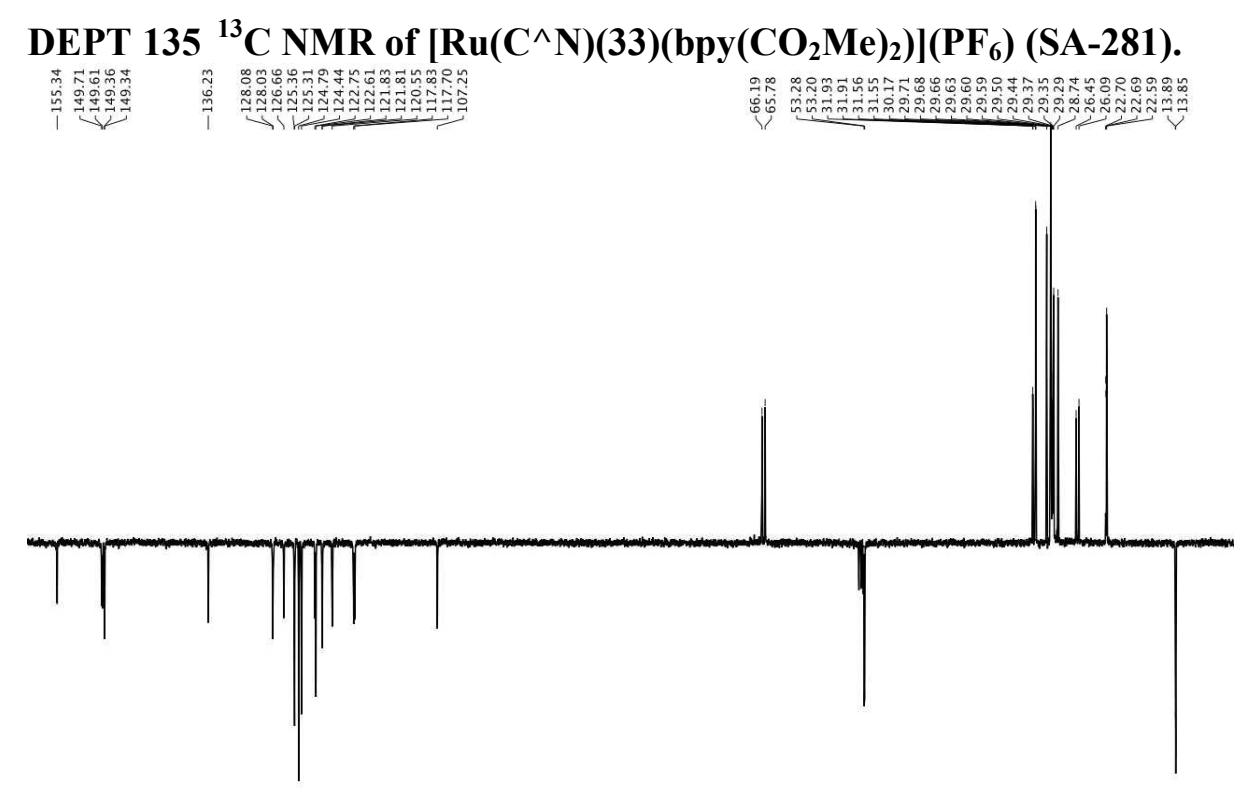

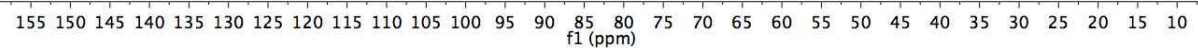

DEPT $135{ }^{13} \mathrm{C} N M R$ (aromatic region) of $\left[\mathrm{Ru}\left(\mathrm{C}^{\wedge} \mathrm{N}\right)(33)\left(\mathrm{bpy}\left(\mathrm{CO}_{2} \mathrm{Me}\right)_{2}\right)\right]\left(\mathrm{PF}_{6}\right)(\mathrm{SA}-281)$.

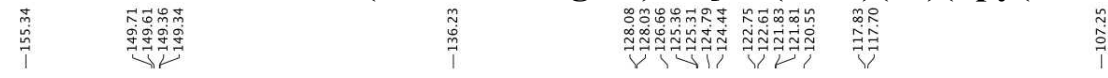

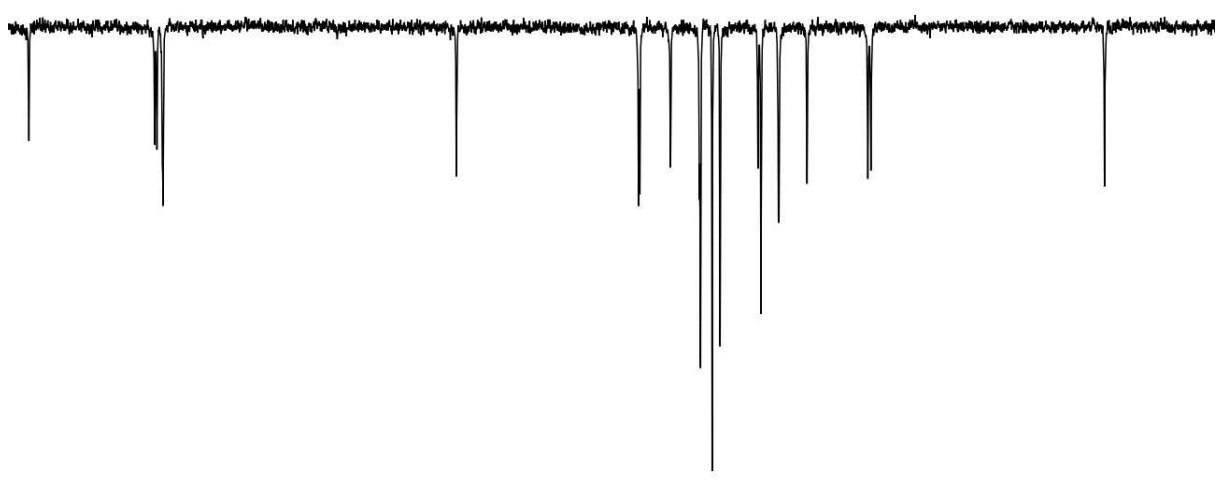

$\begin{array}{lllllllllllllllllllllllllllllll}56 & 154 & 152 & 150 & 148 & 146 & 144 & 142 & 140 & 138 & 136 & 134 & 132 & \begin{array}{l}130 \\ \mathrm{f} 1(\mathrm{ppm})\end{array} & 126 & 124 & 122 & 120 & 118 & 116 & 114 & 112 & 110 & 108 & 106 & 104\end{array}$ 
1H NMR of $\left[\mathrm{Ru}\left(\mathrm{C}^{\wedge} \mathrm{N}\right)(33)\left(\mathrm{bpy}\left(\mathrm{CO}_{2} \mathrm{H}\right)_{2}\right)\right]\left(\mathrm{PF}_{6}\right)(\mathrm{SA}-284)$.
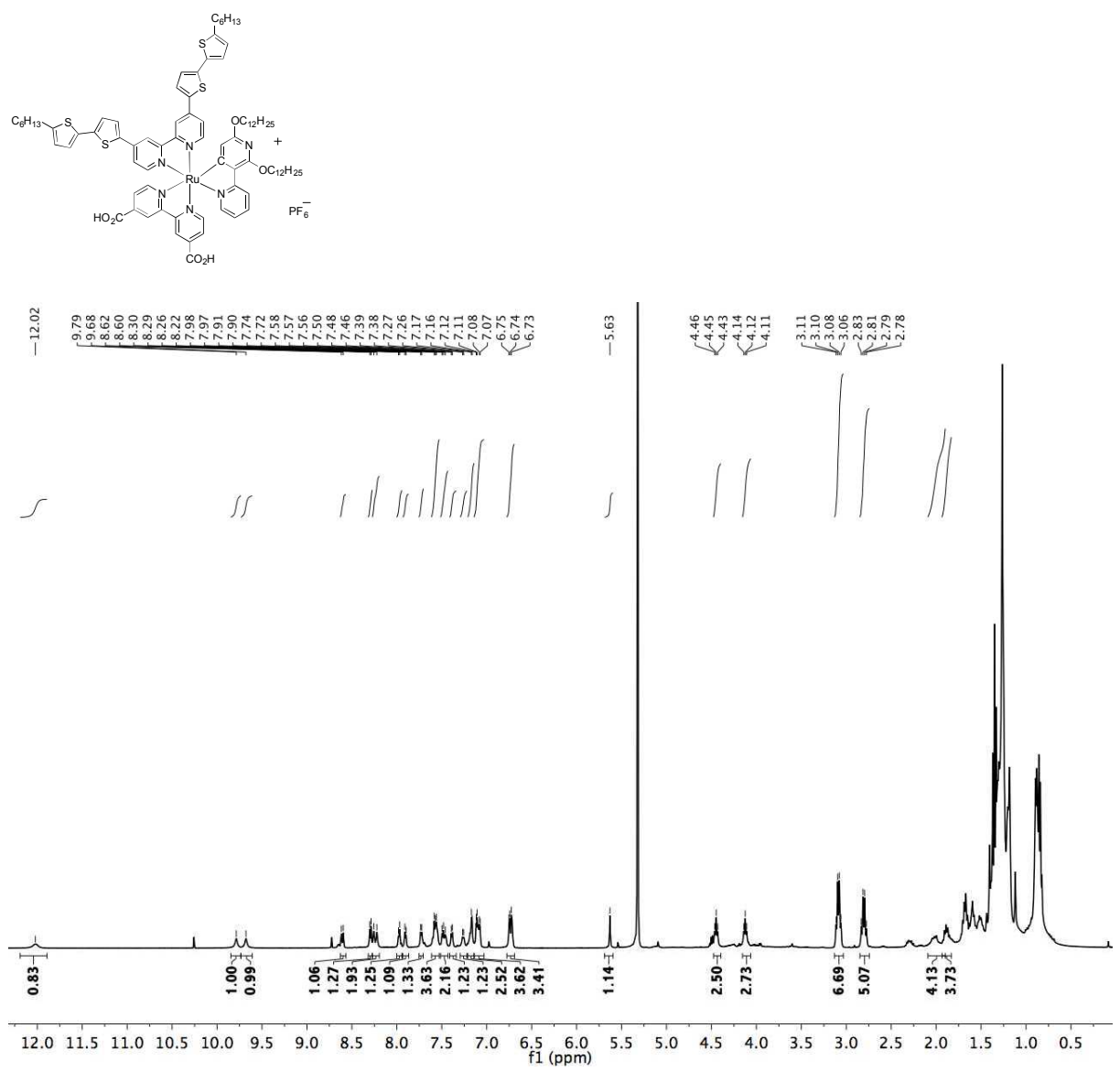

$1 \mathrm{H}$ NMR (aromatic region) of $\left[\mathrm{Ru}\left(\mathrm{C}^{\wedge} \mathrm{N}\right)(33)\left(\mathrm{bpy}\left(\mathrm{CO}_{2} \mathrm{H}\right)_{2}\right)\right]\left(\mathrm{PF}_{6}\right)(\mathrm{SA}-284)$.
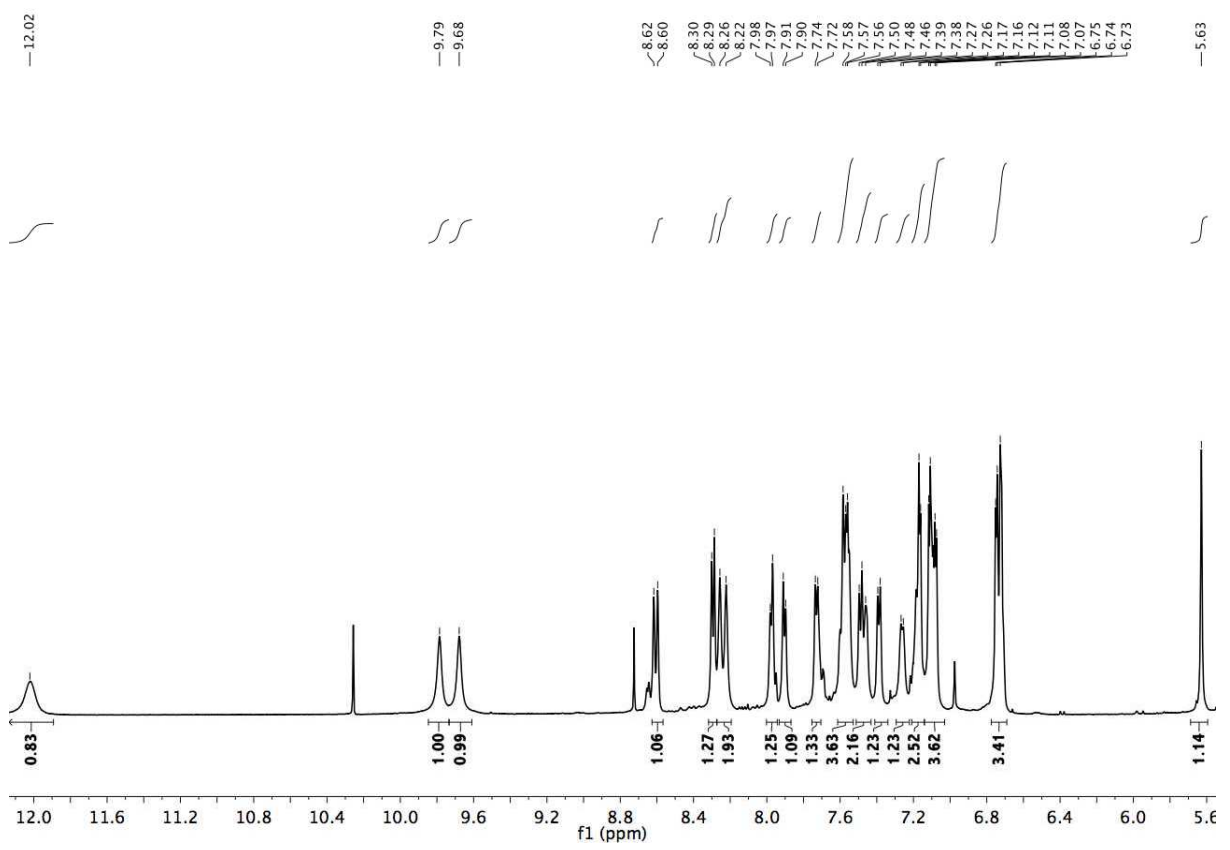

1H NMR of $\left[\mathrm{Ru}\left(\mathrm{C}^{\wedge} \mathrm{N}\right)(31)\left(\mathrm{bpy}\left(\mathrm{CO}_{2} \mathrm{Me}\right)_{2}\right)\right]\left(\mathrm{PF}_{6}\right)(\mathrm{SA}-283)$. 

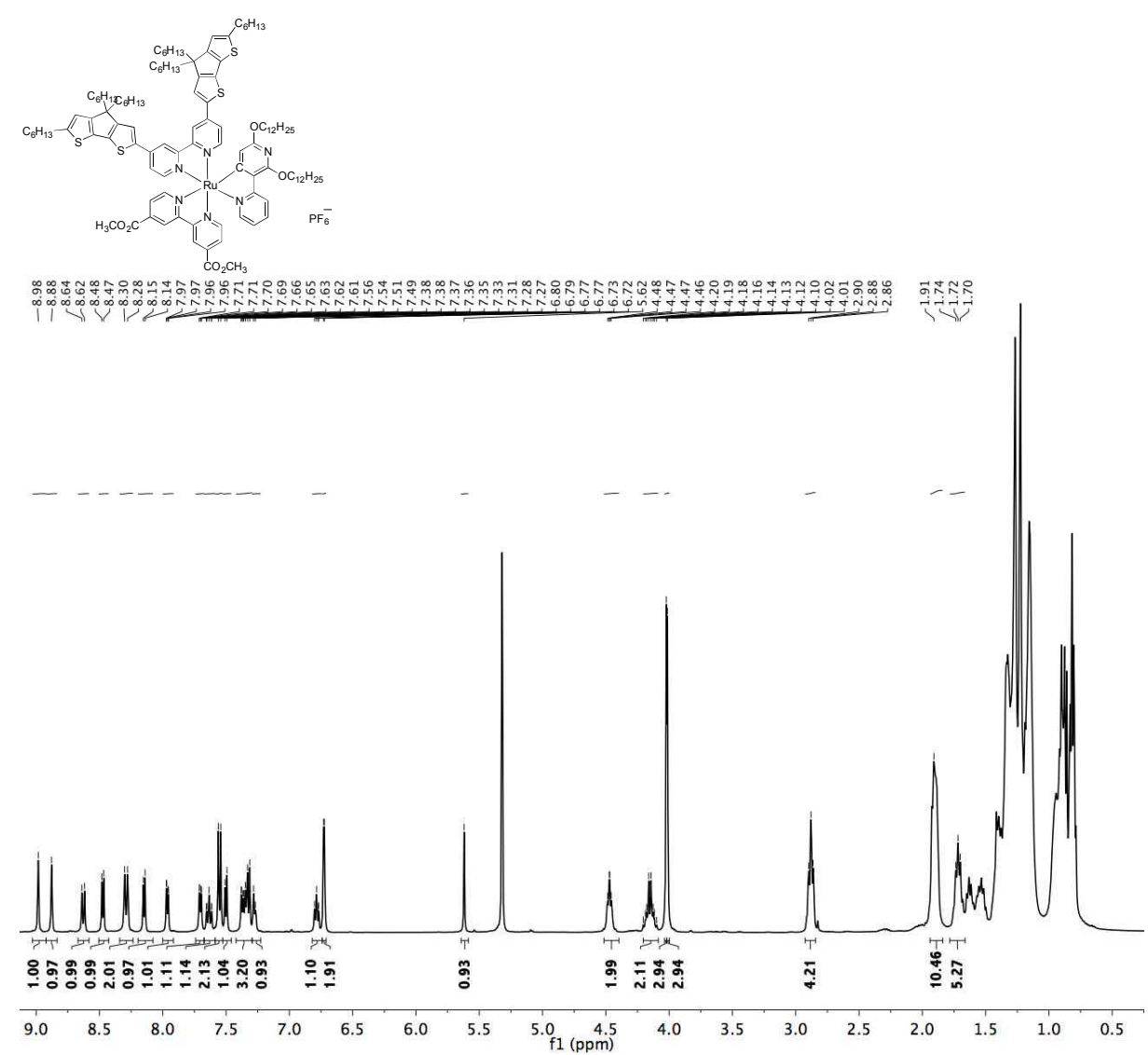

$1 \mathrm{H} N M R$ (aromatic region) of $\left[\mathrm{Ru}\left(\mathrm{C}^{\wedge} \mathrm{N}\right)(31)\left(\mathrm{bpy}\left(\mathrm{CO}_{2} \mathrm{Me}\right)_{2}\right)\right]\left(\mathrm{PF}_{6}\right)(\mathrm{SA}-283)$.

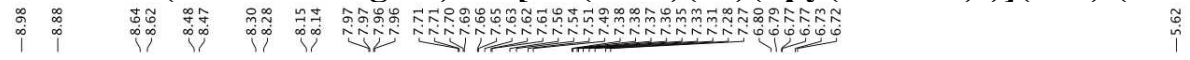

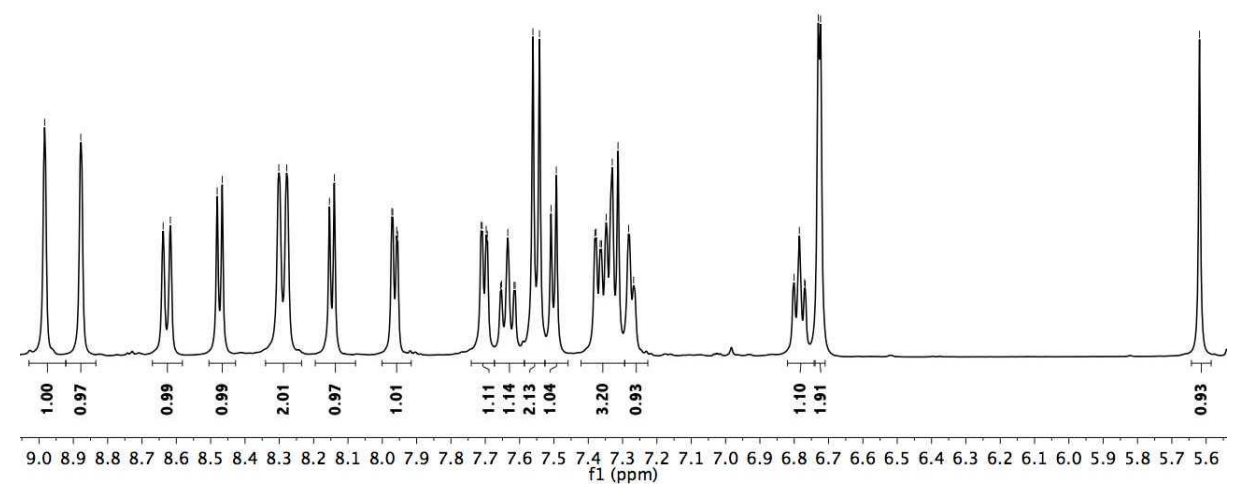


13C NMR of $\left[\mathrm{Ru}\left(\mathrm{C}^{\wedge} \mathrm{N}\right)(31)\left(\mathrm{bpy}\left(\mathrm{CO}_{2} \mathrm{Me}\right)_{2}\right)\right]\left(\mathrm{PF}_{6}\right)(\mathrm{SA}-283)$.

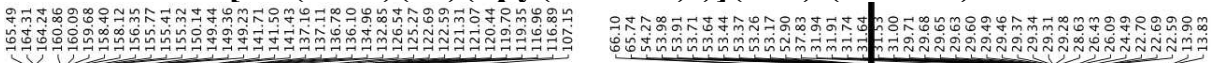

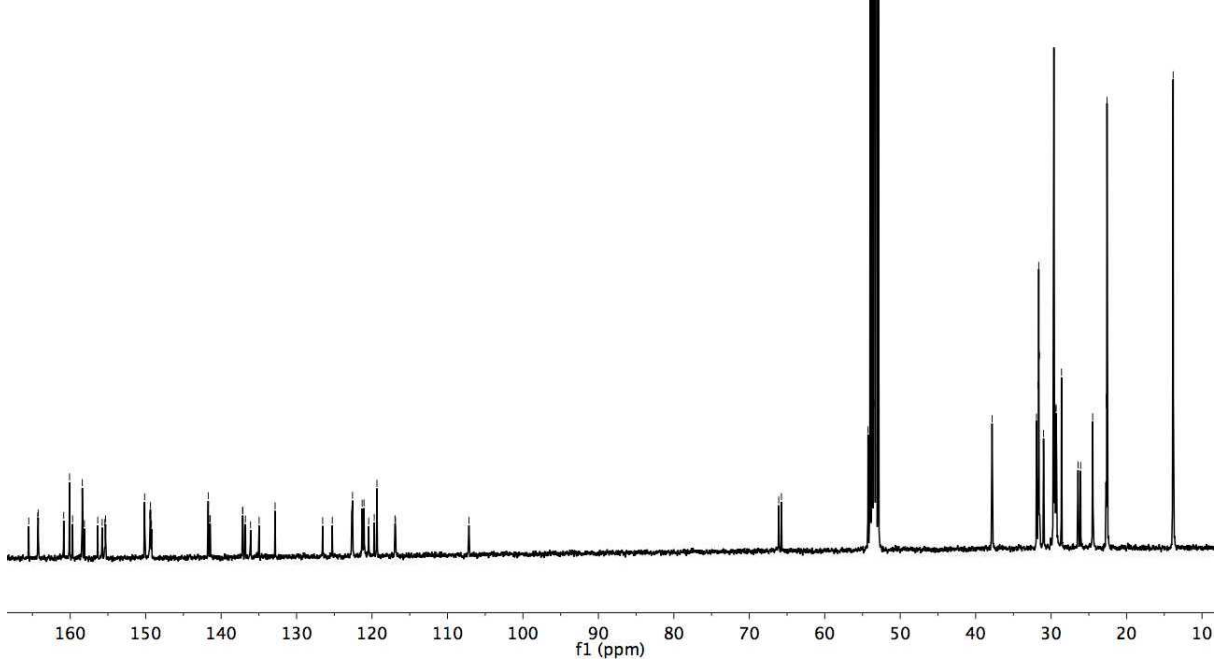

13C NMR (aromatic region) of $\left[\mathrm{Ru}\left(\mathrm{C}^{\wedge} \mathrm{N}\right)(31)\left(\mathrm{bpy}\left(\mathrm{CO}_{2} \mathrm{Me}\right)_{2}\right)\right]\left(\mathrm{PF}_{6}\right)(\mathrm{SA}-283)$.

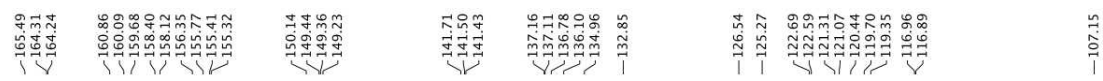

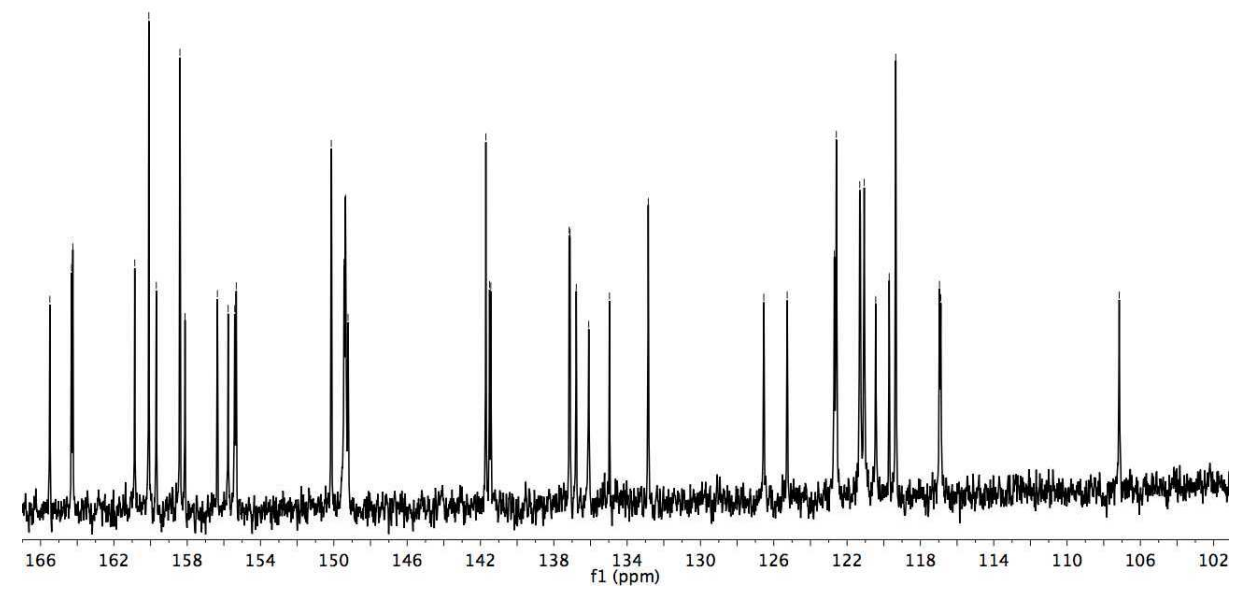


DEPT $135{ }^{13} \mathrm{C}$ NMR of $\left[\mathrm{Ru}\left(\mathrm{C}^{\wedge} \mathrm{N}\right)(31)\left(\mathrm{bpy}\left(\mathrm{CO}_{2} \mathrm{Me}\right)_{2}\right)\right]\left(\mathrm{PF}_{6}\right)(\mathrm{SA}-283)$.

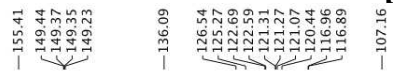

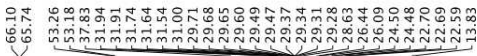
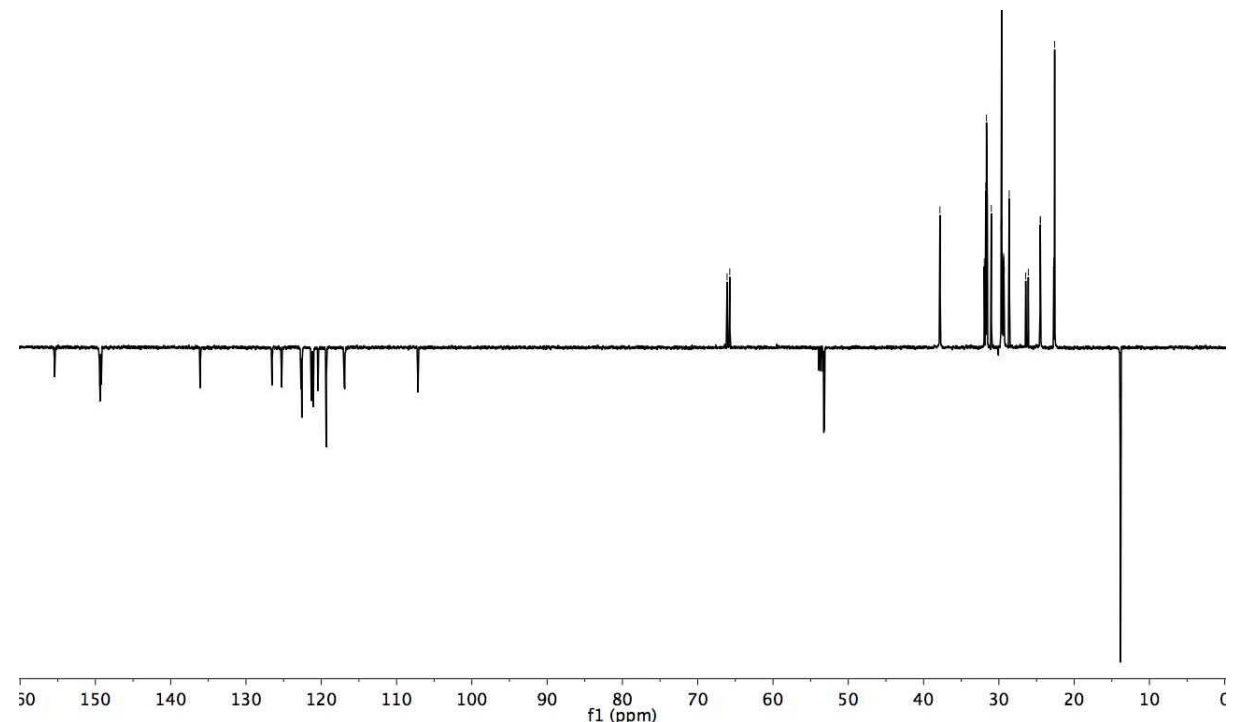

DEPT $135{ }^{13} \mathrm{C} N M R$ (aromatic region) of $\left[\mathrm{Ru}\left(\mathrm{C}^{\wedge} \mathrm{N}\right)(31)\left(\mathrm{bpy}\left(\mathrm{CO}_{2} \mathrm{Me}_{2}\right)\right]\left(\mathrm{PF}_{6}\right)(\mathrm{SA}-283)\right.$.
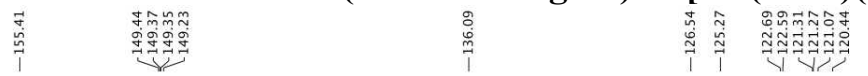

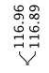

章

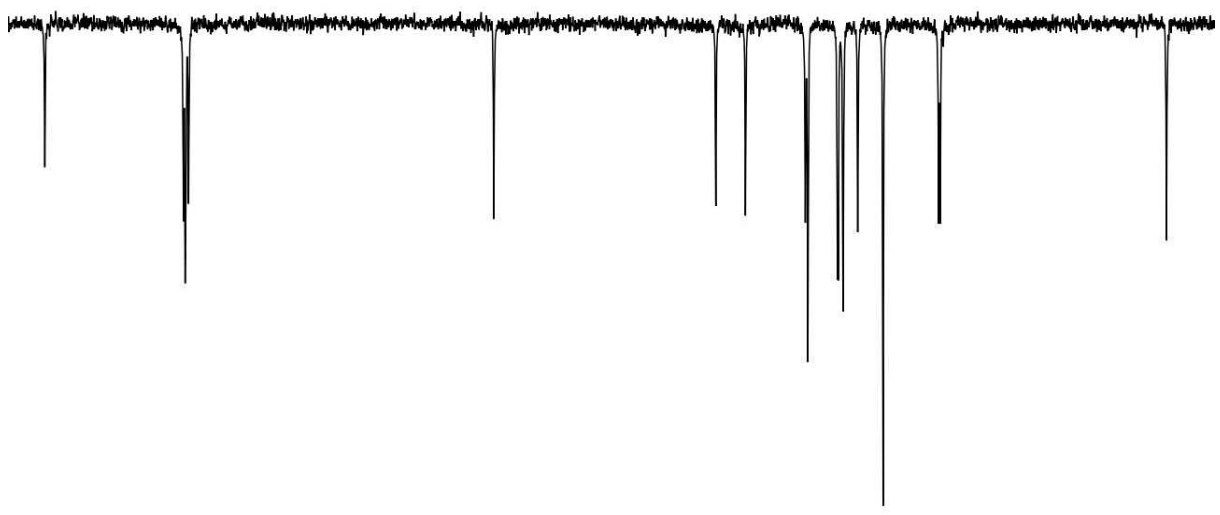

$\begin{array}{llllllllllllllllllllllllll}156 & 154 & 152 & 150 & 148 & 146 & 144 & 142 & 140 & 138 & 136 & 134 & \begin{array}{c}132 \\ \mathrm{f} 1(\mathrm{ppm})\end{array} & 128 & 126 & 124 & 122 & 120 & 118 & 116 & 114 & 112 & 110 & 108 & 106\end{array}$ 
1H NMR of $\left[\mathrm{Ru}\left(\mathrm{C}^{\wedge} \mathrm{N}\right)(31)\left(\mathrm{bpy}\left(\mathrm{CO}_{2} \mathrm{H}\right)_{2}\right)\right]\left(\mathrm{PF}_{6}\right)\left(\mathrm{SA}^{-285}\right)$.

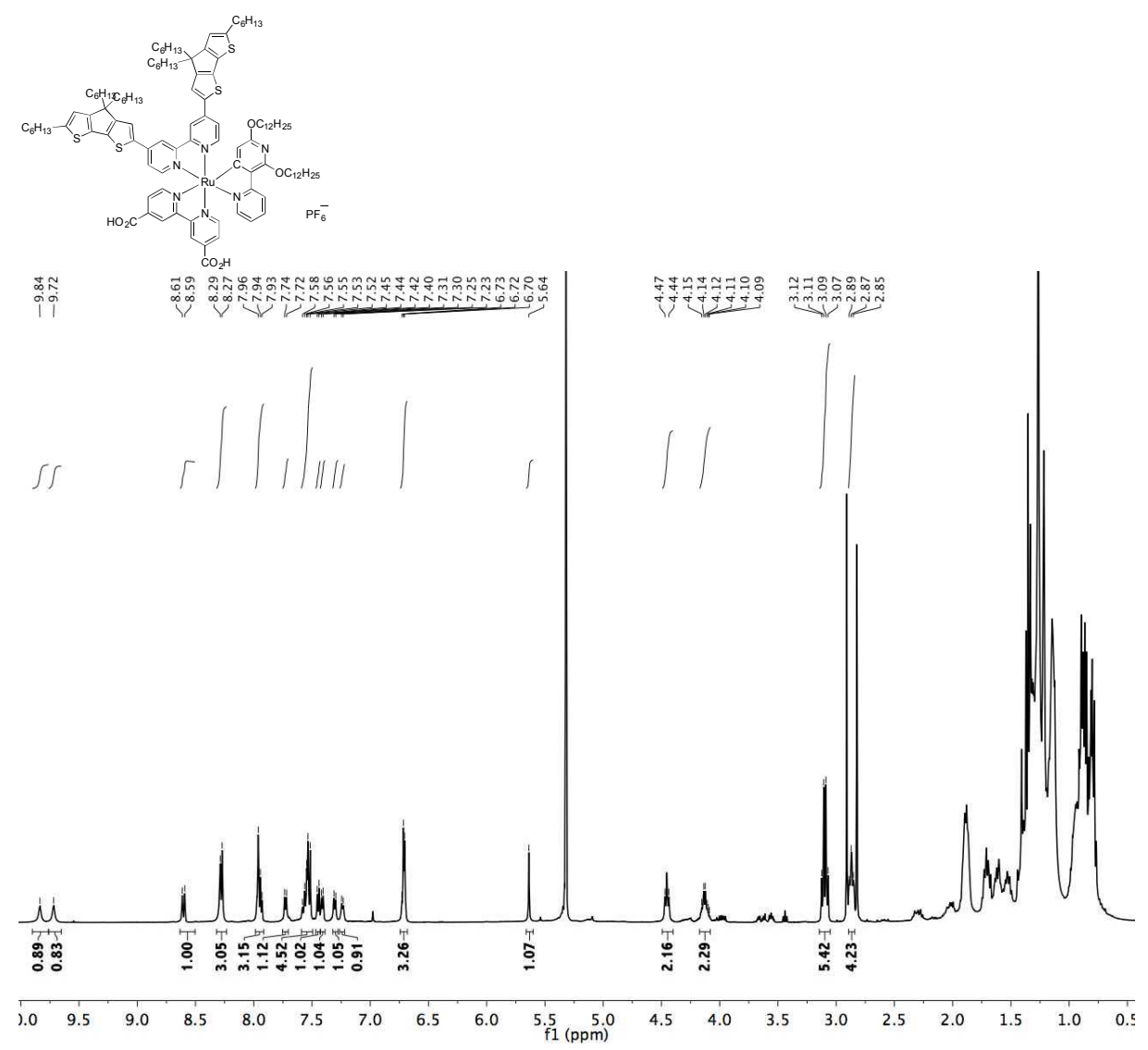

$1 \mathrm{H} N M R$ (aromatic region) of $\left[\mathrm{Ru}\left(\mathrm{C}^{\wedge} \mathrm{N}\right)(31)\left(\mathrm{bpy}\left(\mathrm{CO}_{2} \mathrm{H}\right)_{2}\right)\right]\left(\mathrm{PF}_{6}\right)(\mathrm{SA}-285)$.
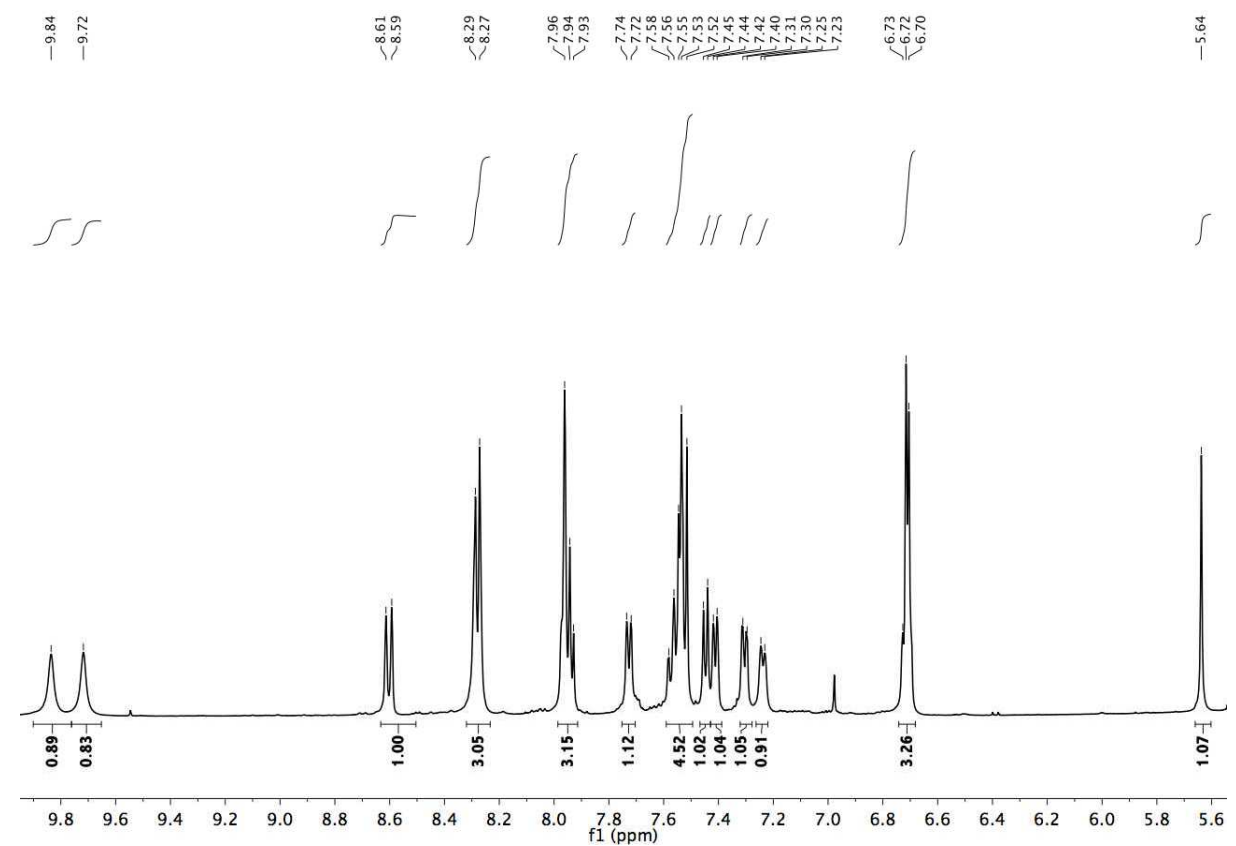

DEPT $135{ }^{13} \mathrm{C} N M R$ of $\left[\mathrm{Ru}\left(\mathrm{C}^{\wedge} \mathrm{N}\right)(31)\left(\mathrm{bpy}\left(\mathrm{CO}_{2} \mathrm{H}\right)_{2}\right)\right]\left(\mathrm{PF}_{6}\right)(\mathrm{SA}-285)$. 


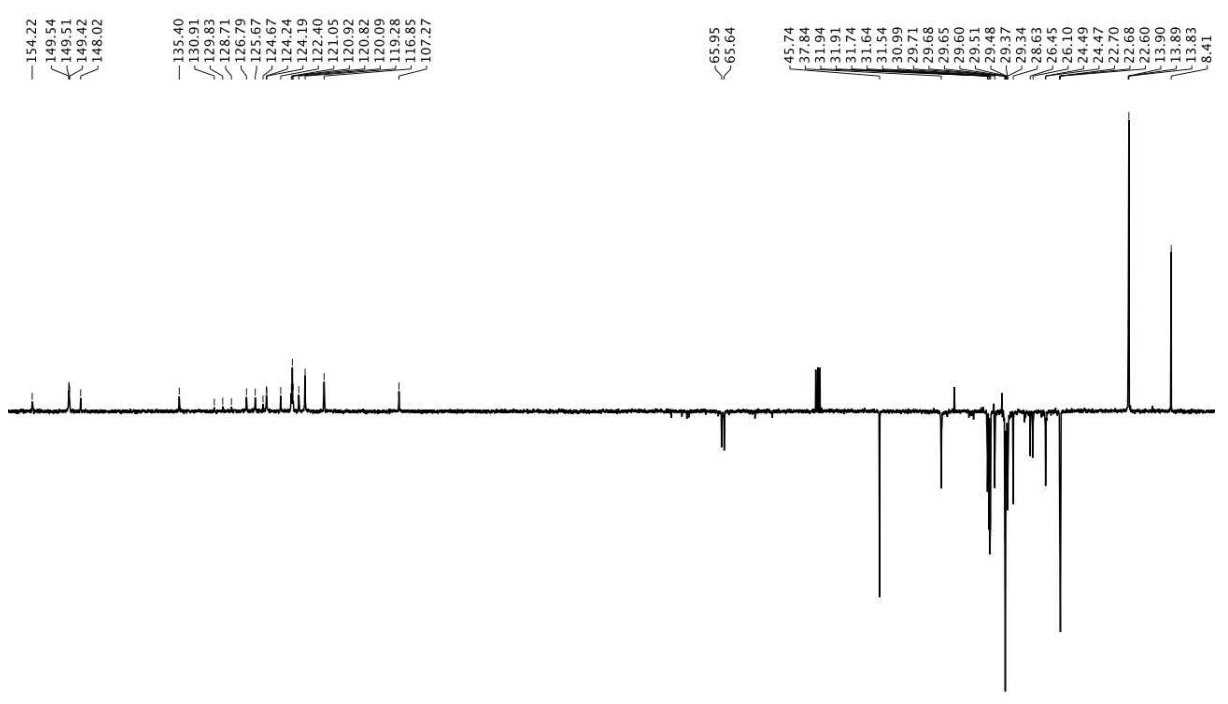

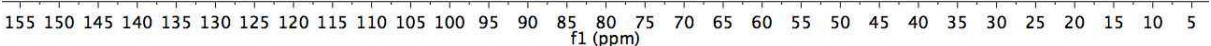

DEPT $135{ }^{13} \mathrm{C}$ NMR (aromatic region) of $\left[\operatorname{Ru}\left(\mathrm{C}^{\wedge} \mathrm{N}\right)(31)\left(\mathrm{bpy}\left(\mathrm{CO}_{2} \mathrm{H}\right)_{2}\right)\right]\left(\mathrm{PF}_{6}\right)(\mathrm{SA}-285)$.

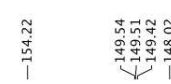

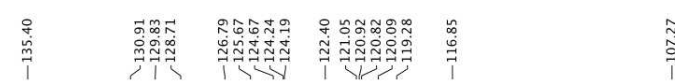

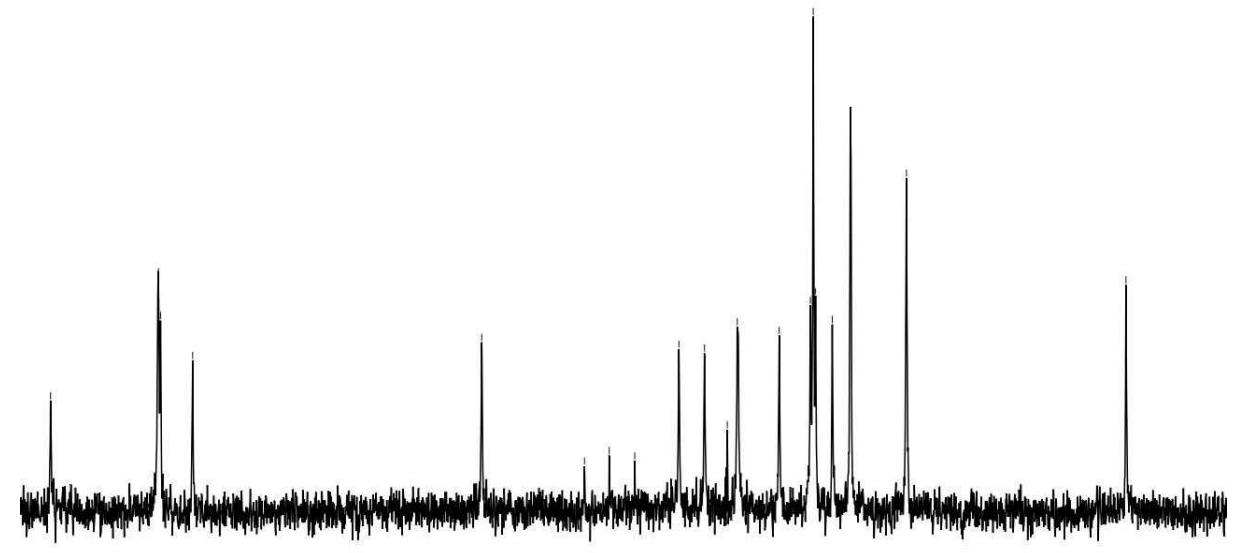

$\begin{array}{llllllllllllllllllllllllllllllll}154 & 152 & 150 & 148 & 146 & 144 & 142 & 140 & 138 & 136 & 134 & 132 & \begin{array}{c}130 \\ \mathrm{f} 1(\mathrm{ppm})\end{array} & 126 & 124 & 122 & 120 & 118 & 116 & 114 & 112 & 110 & 108 & 106 & 104\end{array}$ 


\section{Device Fabrication}

All materials were ordered from commercial suppliers and used without further purification. The DSCs were prepared according to literature procedures describe before. Electrolyte components $-\left[\mathrm{Co}(\mathrm{phen})_{3}\right](\mathrm{TFSI})_{2}$ and $\left[\mathrm{Co}(\mathrm{phen})_{3}\right](\mathrm{TFSI})_{3}$ were synthesized according to the literature methods. ${ }^{18}$

\subsection{Working electrode ${ }^{19}$.}

Working electrode for the iodine-based and cobalt-based devices had different parameters. For the Co-based devices, working electrode was composed of FTO glass (Nippon Sheet Glass, NSG, $10 \Omega / \mathrm{sq}$ ) treated twice with $60 \mathrm{mM}$ aqueous solution of $\mathrm{TiCl}_{4}$ at $70{ }^{\circ} \mathrm{C}$ for 30 minutes and washed thoroughly. $4 \mu \mathrm{m}$ thick titania film with $32 \mathrm{~nm}$ size $\mathrm{TiO}_{2}$ particles and another $4 \mu \mathrm{m}$ thick layer onto with $400 \mathrm{~nm}$ size $\mathrm{TiO}_{2}$ particles were applied according to the procedure described before. Afterwards, electrodes were treated with $25 \mathrm{mM}$ aqueous solution of $\mathrm{TiCl}_{4}$ at $70{ }^{\circ} \mathrm{C}$ for 30 minutes, washed thoroughly with water and dried. Electrodes were heated at $500{ }^{\circ} \mathrm{C}$ for 30 minutes before dipping into the $0.2 \mathrm{mM}$ dye solution in THF/EtOH (3:7). Working electrode for the iodine-based devices were prepared similarly, however, $8 \mu \mathrm{m}$ thick titania film with $18 \mathrm{~nm}$ size $\mathrm{TiO}_{2}$ particles and another $5 \mu \mathrm{m}$ thick layer onto with $400 \mathrm{~nm}$ size $\mathrm{TiO}_{2}$ particles were used.

\subsection{Counter Electrode ${ }^{19}$.}

Before preparation of the counter electrodes (CEs) FTO glass (TEC 7, Dyesol) pieces were heated at $410{ }^{\circ} \mathrm{C}$ for 15 minutes and cooled down to room temperature. For the Co-based devices the CEs were prepared by drop-casting a suspension of graphene nanoparticles (ABCR, Karlsruhe, $6-8 \mathrm{~nm}$ thick, $15 \mu \mathrm{m}$ wide) in acetone $(0.1 \mathrm{mg} / \mathrm{mL})$ onto FTO glass. Then electrodes were dried at room temperature and heated at $410{ }^{\circ} \mathrm{C}$ for 2 minutes. For the iodine-based devices the CEs were prepared by drop-casting a solution of $\mathrm{H}_{2} \mathrm{PtCl}_{6}(5 \mathrm{mM}$ in isopropanol) onto FTO glass (TEC 7 , Dyesol, $7 \Omega / \mathrm{sq}$ ). Then electrodes were dried at room temperature and heated at $410{ }^{\circ} \mathrm{C}$ for 20 minutes.

\subsection{Electrolytes.}

The Co-based electrolytes consist of: 3) $0.25 \mathrm{M}\left[\mathrm{Co}(\mathrm{II})(\text { phen })_{3}\right](\mathrm{TFSI})_{2}, 0.05 \mathrm{M}$ $\left[\mathrm{Co}(\mathrm{III})(\text { phen })_{3}\right](\mathrm{TFSI})_{3}, 0.25 \mathrm{M}$ 4-(5-nonyl)pyridine (NP) and $0.1 \mathrm{M}$ LiTFSI and 4) $0.25 \mathrm{M}$ $\left[\mathrm{Co}(\mathrm{II})(\text { phen })_{3}\right](\mathrm{TFSI})_{2}, 0.05 \mathrm{M}\left[\mathrm{Co}(\mathrm{III})(\text { phen })_{3}\right](\mathrm{TFSI})_{3}, 0.5 \mathrm{M}$ 4-(5-nonyl)pyridine (NP) and 0.1 M LiTFSI.

\subsection{Cell Assembly ${ }^{19}$.}

Counter and working electrodes were sealed with a $25 \mu \mathrm{m}$ thick hot-melt ionomer (Surlyn, DuPont) under heating at $120^{\circ} \mathrm{C}$. Then the electrolyte was introduced through predrilled holes in the CE, which were sealed with a piece of similar ionomer and thin glass at $120{ }^{\circ} \mathrm{C}$. Cells active area was $0.28 \mathrm{~cm}^{2}$ and a black mask with area $0.159 \mathrm{~cm}^{2}$ was used for all photovoltaic studies to provide reliable results. 


\section{Device Characterization}

\subsection{J-V Characterization.}

A solar simulator based on $450 \mathrm{~W}$ xenon light source (Osram XBO 450) with a sunlight filter Schott K113 Tempax (Präzisions Glas \& Optik GmbH, Germany) was used to reduce the mismatch between the simulated and real solar spectra to less than $4 \%$. The lamp power was controlled in respect to the AM 1.5 solar standard employing a reference Si photodiode. The current -voltage characteristics of the device were measured at different sun intensities by applying external voltage bias to the device and measuring photocurrent with a Keithley digital source meter (Keithley 2400, USA). The delay time between applying voltage and measuring generated photocurrent was fixed to $80 \mathrm{~ms}$.

\subsection{Incident Photon-to-Collected Electron Conversion Efficiency (IPCE).}

For IPCE measurements, light from a $300 \mathrm{~W}$ Xenon lamp (ILC Technology, U.S.A.) was focused by Gemini-180 double monochromator (Jobin Yvon Ltd., U.K.) onto the measured device. A white light bias (5\%) was used to ensure total light intensity close to working conditions. The incident light wavelength was incremented by $10 \mathrm{~nm}$ and IPCE was measure in visible region.

\section{Optical and Electrochemical Characterization of sensitizers.}

\subsection{Electronic absorption and emission spectra}

Electronic absorption spectra of dyes were measured in dichloromethane with a Hewlett Packard Diode Array spectrophotometer. Emission spectra were recorded with a Fluorolog Horiba Jobin Yvon Model FL-1065. Absorption and emission spectra sensitized titania films were measured with the same instruments. For the absorption spectra measurements, a mask with area lower than sensitized film area was used. 


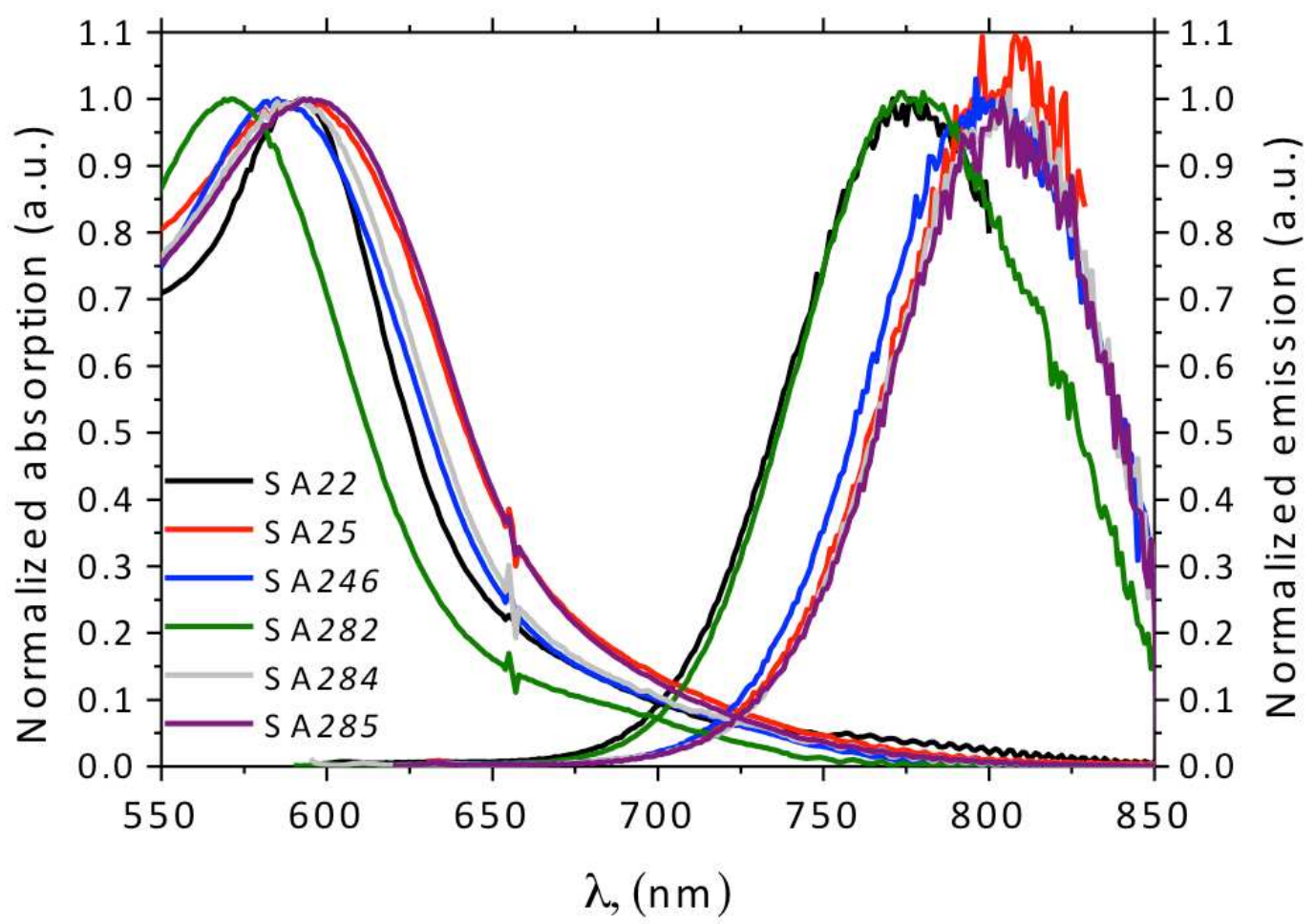

Figure S1 Normalized Absorbance and Emittance of SA dyes

\subsection{Cyclic voltammetry}

To determine dyes oxidation potentials cyclic voltammetry measurements were conducted. A PC controlled AutoLab PSTAT 10 electrochemical workstation was employed. Dyes were dissolved in $0.1 \mathrm{M}$ solution of tetra-n-butylammonium hexafluorophosphate in dichloromethane using a glassy carbon electrode as working and Pt wires as a counter and pseudo-reference electrodes. Measurements were carried out under argon flux. $\mathrm{Fc} / \mathrm{Fc}^{+}$was used as internal standard. $\mathrm{Fc} / \mathrm{Fc}^{+}$, s oxidation potential was fixed at $+0.70 \mathrm{~V}$ vs. NHE to convert potentials to NHE scale.

\subsection{Time-Correlated Single Photon Counting}

Time-Correlated Single Photon Counting (TCSPC) experiments were conducted using the setup for emission spectroscopy coupled with additional FluoroHub (Horiba) unit with TBX04 photomultiplier as a detector. A NanoLed pulsed laser-diode emitting at $406 \mathrm{~nm}$ was used. 


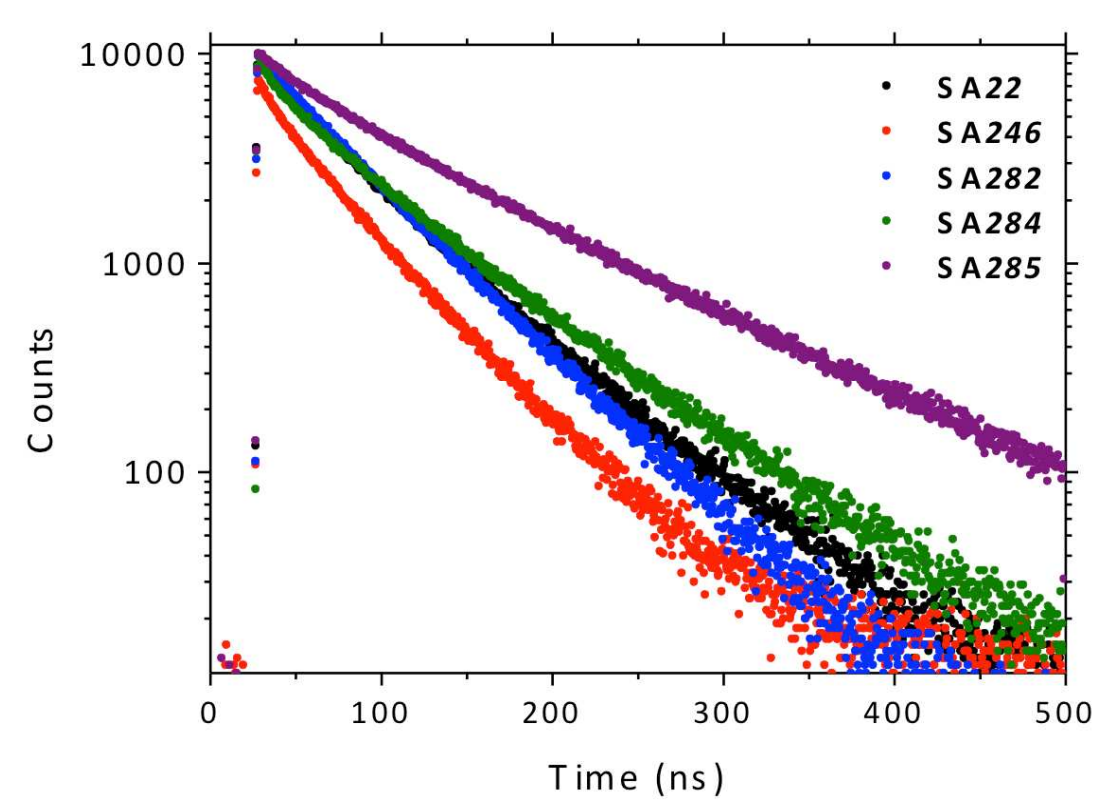

Figure S2 TCSPC measurements in DCM solution

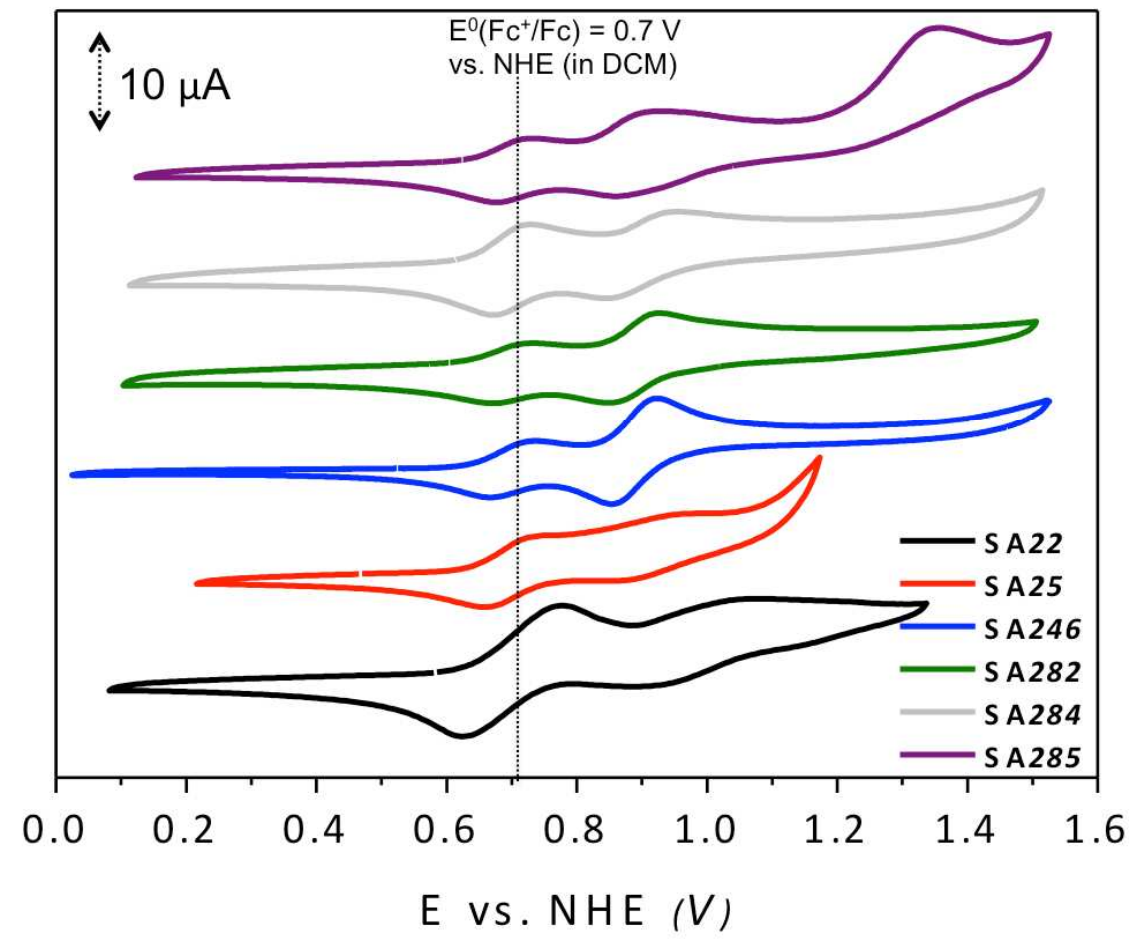

Figure S3 Cyclic voltammograms obtained from the solution in $0.1 \mathrm{M} \mathrm{NBu}_{4} \mathrm{PF}_{6}$ in $\mathrm{DCM}$ under nitrogen atmosphere. Dashed line shows the oxidation potential of ferrocene. Working electrode was glassy carbon, counter and reference electrodes were Pt wires and ferrocen $(\mathrm{Fc})$ was used as internal standard. To calculate the potentials versus NHE, $0.7 \mathrm{~V}$ as Fc oxidation potential was used. 


\subsection{Spectroelectrochemistry}

Spectroeletrochemical measurements were carried out using a PC controlled AutoLab PSTAT 10 electrochemical workstation coupled with a Hewlett Packard Diode Array spectrophotometer. A Pt-mesh working electrode inside a thin-layer quartz cuvette employed with $\mathrm{Pt}$ - wire counter electrode and Ag-wire pseudo-reference electrode was used for measurements. Dye was dissolve in $0.1 \mathrm{M}$ solution of $\mathrm{NBu}_{4} \mathrm{PF}_{6}$ in dichloromethane. First, a potential by $50 \mathrm{mV}$ higher than oxidation wave potential was applied and absorption spectra were measured every 10 second 16 times. Then, applied potential was fixed at a value by $50 \mathrm{mV}$ lower than the reduction wave potential and absorption spectra were measured for every 10 second 16-20 times (Figure S4 (A,B)).

Spectroelectrochemical studies of the complete devices lacking redox shuttle were carried out using the same station described above. The applied potentials for the dye oxidation and reduction were fixed at the potentials relevant to the onset of anodic and cathodic currents (Figure S4. (C)).

Worth to notice that unrecovered MLCT band intensity may result in a loss of a dye during the oxidation. This may cause a drop in $\mathrm{J}_{\mathrm{SC}}$ and $\mathrm{V}_{\mathrm{OC}}$ in a working device. However, one may argue that in the full device a photooxidized dye is regenerated with a reductant present in the electrolyte before going through detrimental destruction. The transient absorbance analysis showed that dye regeneration takes place in the microsecond time scale (vide infra), which competes with other destructive chemical processes. 


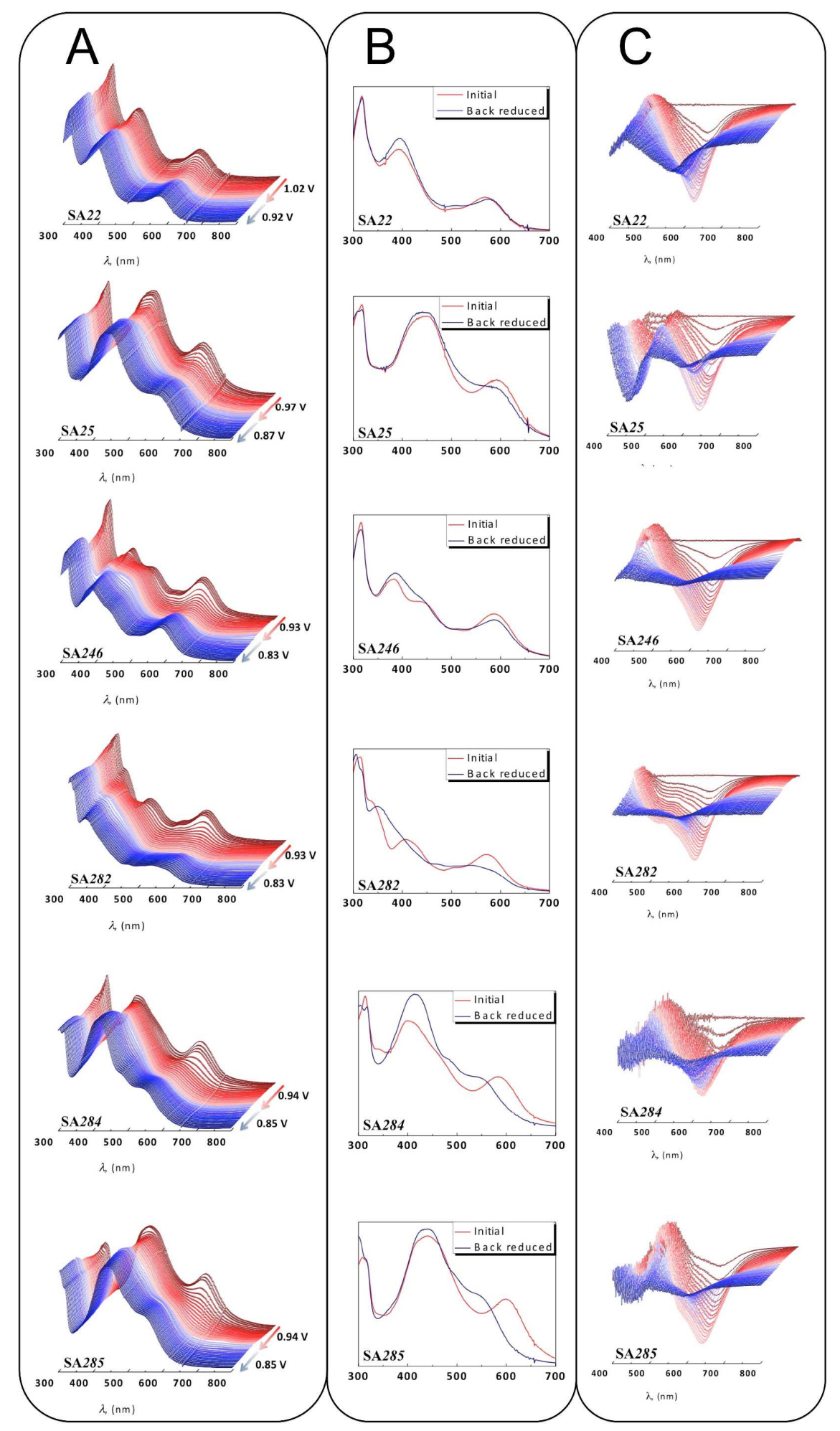

Figure S4. (A) Spectroelectrochemical measurements in $0.1 \mathrm{M} \mathrm{NBu}_{4} \mathrm{PF}_{6} \mathrm{DCM}$ solution of SA dyes. Color change from the red to the pale red and then to the blue visualize the change in spectra during the oxidation and back reduction respectively; (B) Initial and final spectra obtained after back reduction; (C) Spectroelectrochemical measurements in a full device lacking redox shuttle with sensitized SA dyes titania films. Color change from the red to the pale red and then to the blue visualize the change in spectra during the oxidation and back reduction respectively. The starting spectrum was taken as a baseline. 


\section{Dye Desorption Measurements}

To analyze the amount of the dye chemisorbed on the surface, we put dye-sensitized photoanodes into a vial containing $3 \mathrm{~mL}$ of DCM. Then few drops of $0.1 \mathrm{M} \mathrm{NBu}_{4} \mathrm{OH}$ in ethanol were added. After 4 hours the electrode converted completely white. The electrode was taken out, washed with few milliliters of DCM and the volume of the dye solution was brought to 10 $\mathrm{mL}$. Absorption spectra were measured and the amount of chemisorbed dye was calculated using Beer-Lambert-Bouguer law on the most redshifted MLCT band maximum. Due-to dye deprotonation, blue shift of the absorption band maximum position within few nanometers were observed. We considered, that dye deprotonation is not changing the extinction coefficient significantly. Due to the inconsistencies in the electrode thickness, we have repeated the experiment at least three times with all dyes until obtaining the consistent result (error within 5 $\%)$.

\section{Computational Results}

All the calculations have been performed by the GAUSSIAN 09 program package. ${ }^{20} \mathrm{We}$ optimized the molecular structure of the full protonated complexes in vacuum using the B3LYP exchange-correlation functional ${ }^{21}$ and a $3-21 G^{*}$ basis set. $^{22}$ TDDFT calculations of the lowest singlet-singlet excitations were performed in DCM solution on the structure optimized in vacuum and using a DGDZVP basis set. ${ }^{23}$ The non-equilibrium version of C-PCM ${ }^{24-26}$ was employed for TDDFT calculations, as implemented in G09. To simulate the optical spectra, the 70 lowest spin-allowed singlet-singlet transitions were computed on the ground state geometry. Transition energies and oscillator strengths were interpolated by a Gaussian convolution with a $\sigma$ value of $0.13 \mathrm{eV}$.

Optimized geometries of SA series dyes are shown in Figure S6. Cyclometalated pyridine ring was fixed in trans-position to the anchoring carboxypyridine ring 


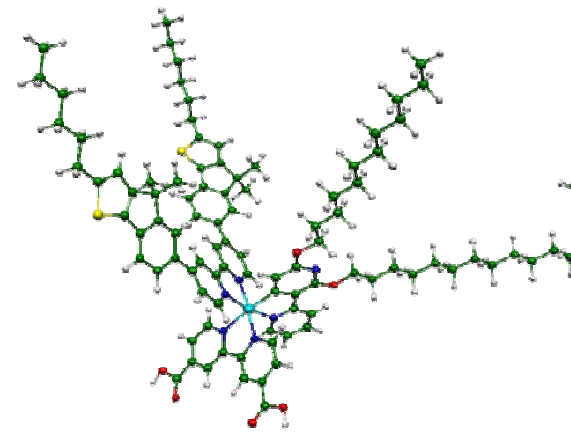

SA22

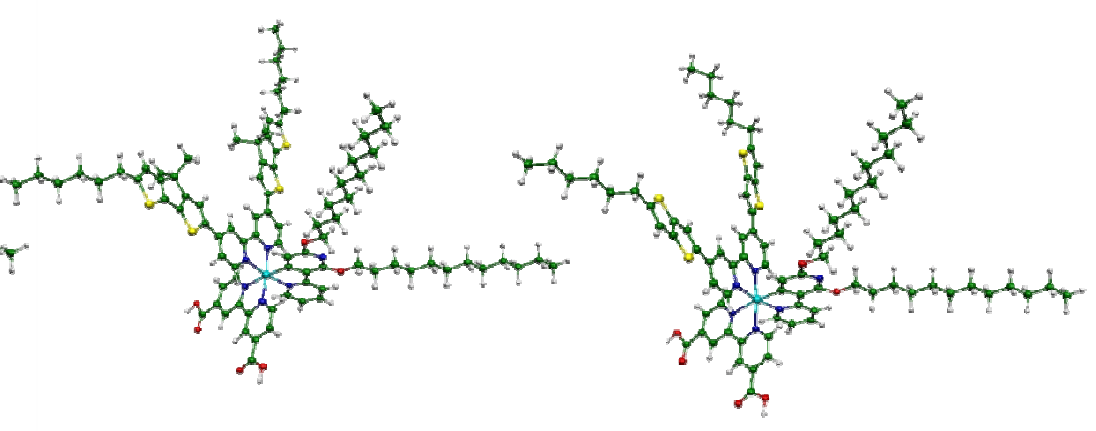

SA25

SA246

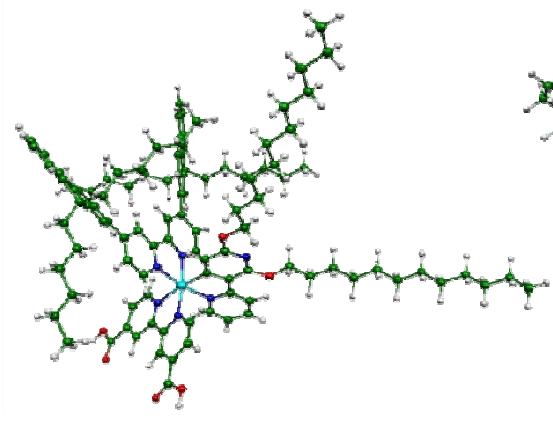

SA282

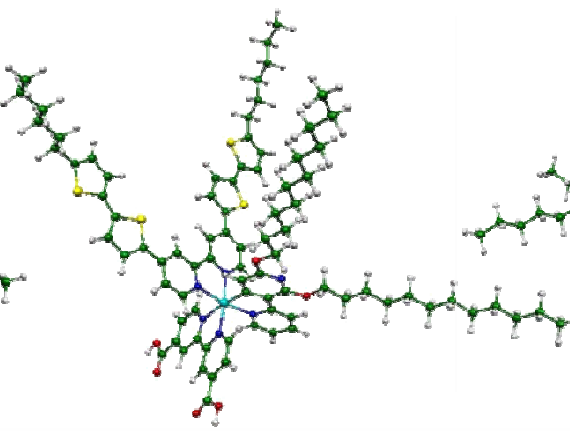

SA284

SA285

Figure S5. Optimized geometry of investigated SA dyes. Balls' colors: light blue (Ru), green (C), white $(\mathrm{H})$, blue $(\mathrm{N})$, yellow (S) 


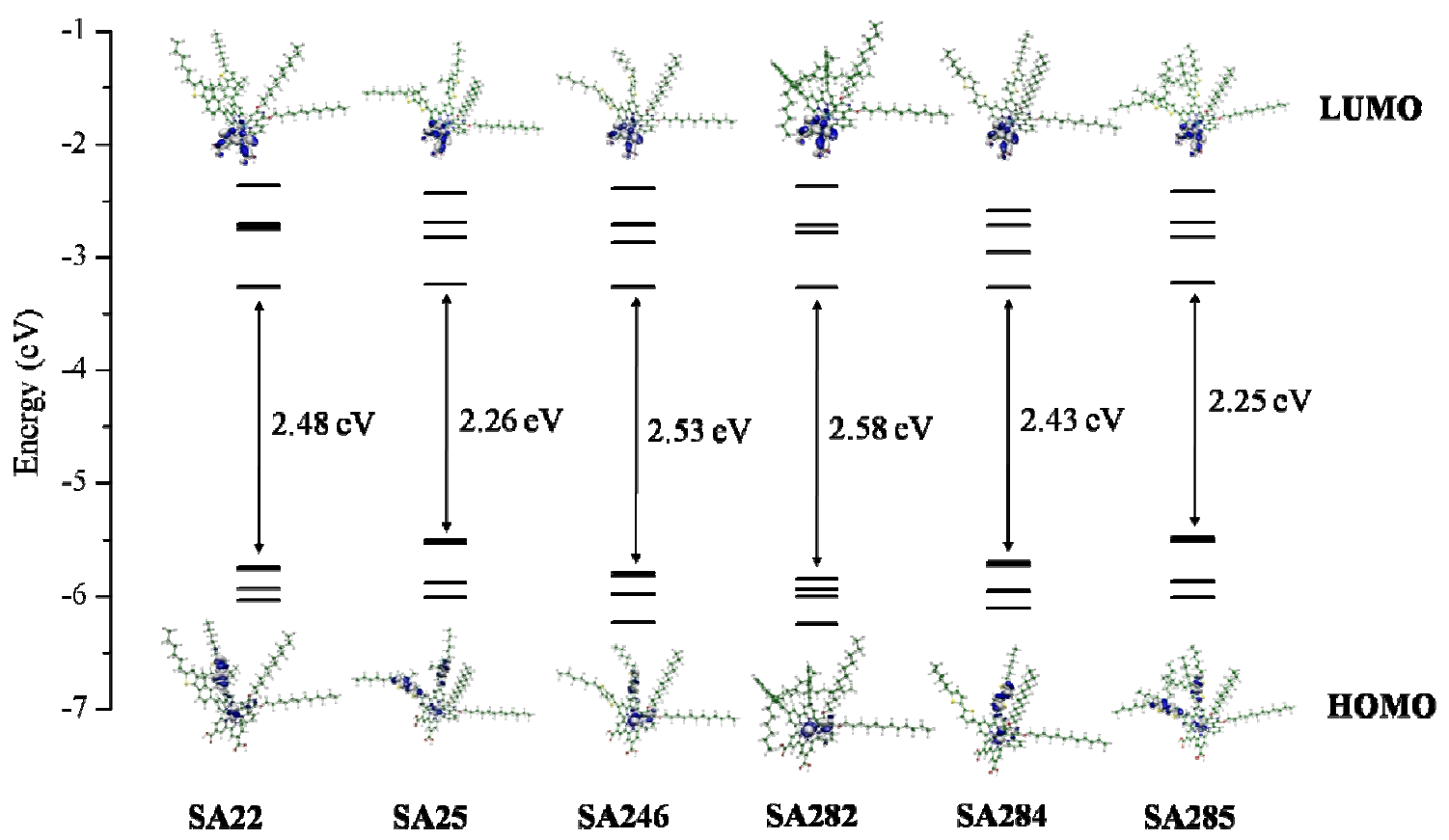

Figure S6. Plot of relevant molecular orbitals energy (in eV). HOMO and LUMO isodensity plots are also reported.

Table S1. Calculated molecular volume and the key dihedral angles

\begin{tabular}{|c|c|c|}
\hline & $\begin{array}{c}\text { Molecular } \\
\text { Volume }\left(\boldsymbol{(}^{\mathbf{3}}\right)\end{array}$ & $\begin{array}{c}\text { Dihedral angle between the aromatic substituents and } \\
\text { pyridine ring in the auxiliary ligands (in degrees) }\end{array}$ \\
\hline SA22 & 2201 & $\sim 36$ \\
\hline SA25 & 2179 & $\sim 9$ \\
\hline SA246 & 1980 & $\sim 0$ \\
\hline SA282 & 2420 & $\sim 38$ \\
\hline SA284 & 2060 & $\sim 1.5$ and 10 \\
\hline SA285 & 2687 & $\sim 8$ and 10 \\
\hline
\end{tabular}

Table S2. Calculated molecular orbitals energies $(\mathrm{eV})$ in DCM solvent of investigated dyes. The energies were calculated at B3LYP/3-21G* level.

\begin{tabular}{|c|c|c|c|c|c|c|}
\hline & SA22 & SA25 & SA246 & SA282 & SA284 & SA285 \\
\hline $\mathbf{L}+3$ & -2.36 & -2.43 & -2.39 & -2.37 & -2.59 & -2.42 \\
\hline $\mathbf{L}+\mathbf{2}$ & -2.71 & -2.69 & -2.71 & -2.72 & -2.72 & -2.69 \\
\hline $\mathbf{L}+\mathbf{1}$ & -2.75 & -2.83 & -2.87 & -2.78 & -2.95 & -2.82 \\
\hline $\mathbf{L}$ & -3.26 & -3.24 & -3.26 & -3.27 & -3.27 & -3.23 \\
\hline $\mathbf{H}$ & -5.74 & -5.50 & -5.79 & -5.85 & -5.70 & -5.48 \\
\hline $\mathbf{H}-1$ & -5.76 & -5.53 & -5.82 & -5.94 & -5.73 & -5.51 \\
\hline $\mathbf{H}-2$ & -5.93 & -5.88 & -5.98 & -6.00 & -5.95 & -5.87 \\
\hline H-3 & -6.04 & -6.01 & -6.23 & -6.25 & -6.11 & -6.01 \\
\hline H-L Gap & 2.48 & 2.26 & 2.53 & 2.58 & 2.43 & 2.25 \\
\hline
\end{tabular}

In Table S3 the comparison between experimental electrochemical potentials and calculated HOMO/LUMO energies is reported. To note that the experimental electrochemical 
potentials were converted using the value of $-4.43 \mathrm{eV}$ for the vacuum level with respect to the NHE electrode. ${ }^{27}$

Table S3. Experimental electrochemical potentials (in $\mathrm{eV}$ ) and calculated HOMOs and LUMOs energies.

\begin{tabular}{|c|c|c|c|c|}
\hline & \multicolumn{2}{|c|}{ Experimental } & \multicolumn{2}{c|}{ Calculated } \\
\hline & $\begin{array}{c}\mathrm{E}^{0}\left(\mathrm{~S}^{+} / \mathrm{S}\right) \\
(\mathrm{eV})\end{array}$ & $\begin{array}{c}\mathrm{E}^{0}\left(\mathrm{~S}^{+} / \mathrm{S}^{*}\right) \\
(\mathrm{eV})\end{array}$ & $\begin{array}{c}\text { HOMO } \\
(\mathrm{eV})\end{array}$ & $\begin{array}{c}\text { LUMO } \\
(\mathrm{eV})\end{array}$ \\
\hline SA22 & -5.40 & -3.63 & -5.74 & -3.26 \\
\hline SA25 & -5.35 & -3.64 & -5.50 & -3.24 \\
\hline SA246 & -5.31 & -3.59 & -5.79 & -3.26 \\
\hline SA282 & -5.31 & -3.54 & -5.85 & -3.27 \\
\hline SA284 & -5.32 & -3.61 & -5.70 & -3.27 \\
\hline SA285 & -5.32 & -3.61 & -5.48 & -3.23 \\
\hline
\end{tabular}

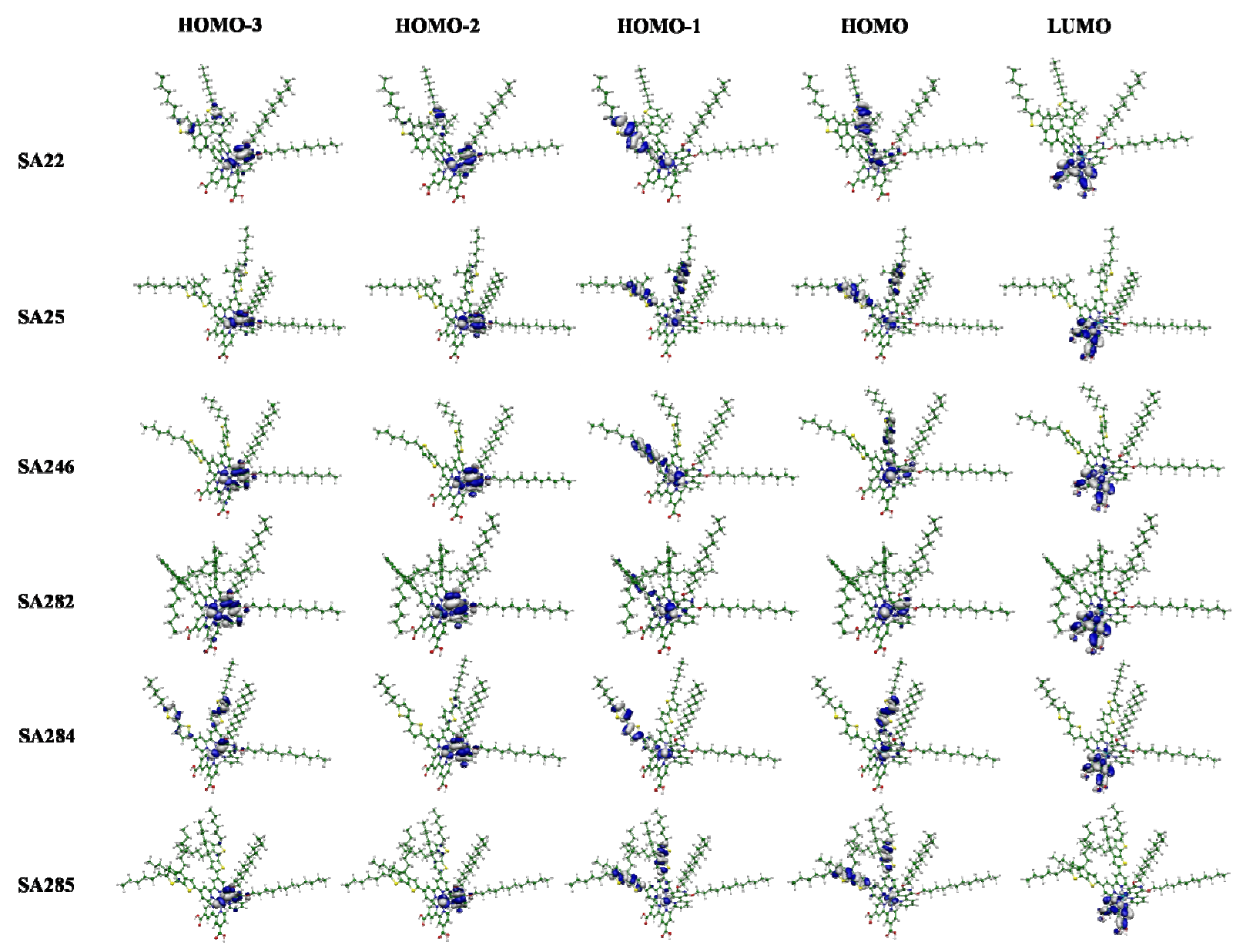

Figure S7. Isodensity plots of relevant molecular orbitals of SA dyes. The atoms colors is the same of optimized geometries in Figure 1. 
The calculated absorption spectra of SA dyes are shown in Figure S8 and the comparison between experimental and theoretical absorption maxima is reported in Table S4.
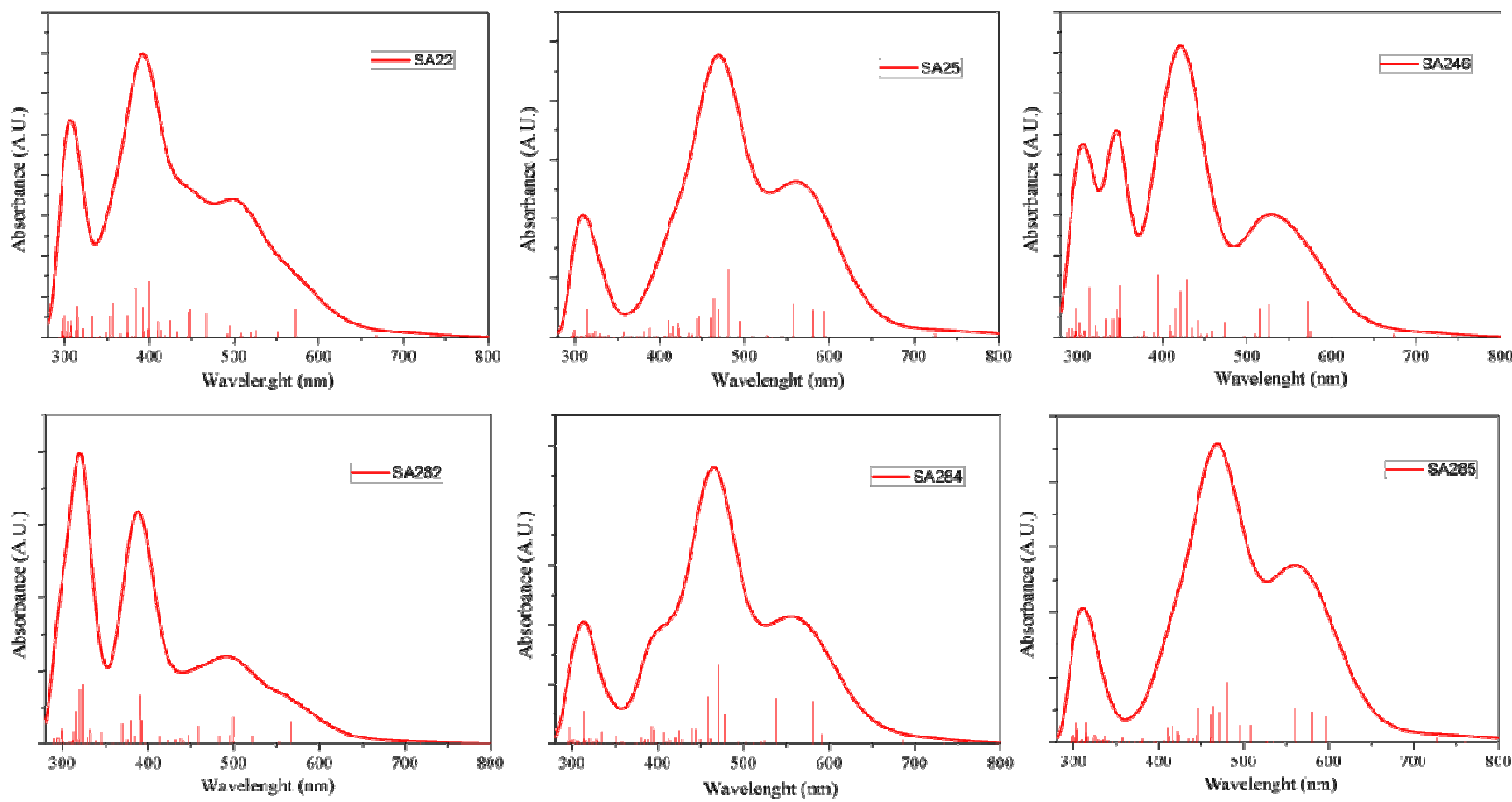

Figure S8. Calculated UV-vis absorption spectra in DCM solvent of SA dyes. The calculated transitions (vertical sticks) are also reported.

Table S4. Experimental and calculated absorption maxima wavelengths (in $\mathrm{nm}$ ) and excitation energy (in eV).

\begin{tabular}{|c|c|c|c|c|}
\hline & \multicolumn{2}{|c|}{ Experimental } & \multicolumn{2}{c|}{ Calculated } \\
\hline & $\lambda_{\max }(\mathbf{n m})$ & $\mathbf{E}_{\text {ex. }}(\mathbf{e V})$ & $\boldsymbol{\lambda}_{\max }(\mathbf{n m})$ & $\left.\mathbf{E}_{\mathbf{e x .}} \mathbf{( e V}\right)$ \\
\hline \multirow{3}{*}{ SA22 } & 592 & 2.09 & 573 & 2.16 \\
& 511 & 2.42 & 506 & 2.45 \\
& 399 & 3.11 & 399 & 3.10 \\
\hline \multirow{2}{*}{ SA25 } & 593 & 2.09 & 596 & 2.08 \\
& 448 & 2.77 & 464 & 2.67 \\
\hline \multirow{3}{*}{ SA246 } & 585 & 2.12 & 572 & 2.17 \\
& $431^{\text {sh }}$ & 2.88 & 429 & 2.89 \\
& 382 & 3.25 & 395 & 3.14 \\
\hline \multirow{3}{*}{ SA282 } & 571 & 2.17 & 567 & 2.19 \\
& $508^{\text {sh }}$ & 2.44 & 499 & 2.48 \\
\multirow{2}{*}{ SA284 } & 411 & 3.02 & 392 & 3.16 \\
& 592 & 2.09 & 581 & 2.13 \\
\multirow{2}{*}{ SA285 } & 398 & 3.11 & 393 & 3.15 \\
& 595 & 2.08 & 581 & 2.13 \\
& 456 & 2.72 & 465 & 2.67 \\
\hline
\end{tabular}




\begin{tabular}{|c|c|c|c|c|c|c|}
\hline Complex & N state & $E(e V)$ & WL (nm) & f & \multicolumn{2}{|c|}{ Composition } \\
\hline \multirow{3}{*}{ SA22 } & 3 & 2.1620 & 573.47 & 0.1737 & $\begin{array}{l}47 \\
26 \\
10\end{array}$ & $\begin{array}{l}\mathrm{H}-2 \rightarrow \mathrm{L} \\
\mathrm{H}-3 \rightarrow \mathrm{L} \\
\mathrm{H}-1 \rightarrow \mathrm{L}\end{array}$ \\
\hline & 8 & 2.4512 & 505.82 & 0.2892 & $\begin{array}{l}34 \\
23 \\
11 \\
\end{array}$ & $\begin{array}{l}\mathrm{H} \rightarrow \mathrm{L}+2 \\
\mathrm{H}-1 \rightarrow \mathrm{L}+1 \\
\mathrm{H}-4 \rightarrow \mathrm{L}\end{array}$ \\
\hline & 22 & 3.1048 & 399.33 & 0.3450 & 64 & $\mathrm{H} \rightarrow \mathrm{L}+4$ \\
\hline \multirow[b]{2}{*}{ SA25 } & 3 & 2.0809 & 595.81 & 0.2195 & $\begin{array}{l}51 \\
19\end{array}$ & $\begin{array}{l}\mathrm{H}-2 \rightarrow \mathrm{L} \\
\mathrm{H}-1 \rightarrow \mathrm{L}\end{array}$ \\
\hline & 14 & 2.672 & 464.01 & 0.3244 & $\begin{array}{l}36 \\
21 \\
15\end{array}$ & $\begin{array}{l}\mathrm{H}-1 \rightarrow \mathrm{L}+3 \\
\mathrm{H}-1 \rightarrow \mathrm{L}+4 \\
\mathrm{H}-2 \rightarrow \mathrm{L}+2\end{array}$ \\
\hline \multirow{3}{*}{ SA246 } & 4 & 2.1684 & 571.78 & 0.225 & 75 & $\mathrm{H}-2 \rightarrow \mathrm{L}$ \\
\hline & 16 & 2.891 & 428.86 & 0.3553 & $\begin{array}{l}36 \\
29 \\
14 \\
13\end{array}$ & $\begin{array}{l}\mathrm{H}-1 \rightarrow \mathrm{L}+4 \\
\mathrm{H}-1 \rightarrow \mathrm{L}+3 \\
\mathrm{H} \rightarrow \mathrm{L}+4 \\
\mathrm{H} \rightarrow \mathrm{L}+3\end{array}$ \\
\hline & 24 & 3.1384 & 395.06 & 0.3776 & $\begin{array}{l}36 \\
23\end{array}$ & $\begin{array}{l}\mathrm{H}-1 \rightarrow \mathrm{L}+5 \\
\mathrm{H}-5 \rightarrow \mathrm{L}+1\end{array}$ \\
\hline \multirow{3}{*}{ SA282 } & 3 & 2.1864 & 567.06 & 0.1471 & $\begin{array}{l}74 \\
10\end{array}$ & $\begin{array}{l}\mathrm{H}-2 \rightarrow \mathrm{L} \\
\mathrm{H}-1 \rightarrow \mathrm{L}\end{array}$ \\
\hline & 6 & 2.4831 & 499.3 & 0.1818 & $\begin{array}{l}51 \\
30\end{array}$ & $\begin{array}{l}\mathrm{H} \rightarrow \mathrm{L}+2 \\
\mathrm{H}-1 \rightarrow \mathrm{L}+1\end{array}$ \\
\hline & 19 & 3.1559 & 392.87 & 0.161 & $\begin{array}{l}52 \\
19\end{array}$ & $\begin{array}{l}\mathrm{H} \rightarrow \mathrm{L}+4 \\
\mathrm{H} \rightarrow \mathrm{L}+5\end{array}$ \\
\hline \multirow{2}{*}{ SA284 } & 3 & 2.0962 & 591.48 & 0.0847 & $\begin{array}{l}58 \\
21 \\
10\end{array}$ & $\begin{array}{l}\mathrm{H}-1 \rightarrow \mathrm{L}+1 \\
\mathrm{H} \rightarrow \mathrm{L}+1 \\
\mathrm{H}-3 \rightarrow \mathrm{L}+1\end{array}$ \\
\hline & 27 & 3.1547 & 393.02 & 0.1467 & $\begin{array}{l}46 \\
28 \\
15 \\
\end{array}$ & $\begin{array}{l}\mathrm{H}-5 \rightarrow \mathrm{L}+2 \\
\mathrm{H}-3 \rightarrow \mathrm{L}+3 \\
\mathrm{H}-4 \rightarrow \mathrm{L}+2\end{array}$ \\
\hline \multirow[b]{2}{*}{ SA285 } & 4 & 2.1339 & 581.03 & 0.2397 & $\begin{array}{l}66 \\
14\end{array}$ & $\begin{array}{l}\mathrm{H}-1 \rightarrow \mathrm{L}+1 \\
\mathrm{H}-2 \rightarrow \mathrm{L}+1\end{array}$ \\
\hline & 14 & 2.6673 & 464.84 & 0.2803 & $\begin{array}{l}33 \\
28 \\
10\end{array}$ & $\begin{array}{l}\mathrm{H}-1 \rightarrow \mathrm{L}+3 \\
\mathrm{H}-1 \rightarrow \mathrm{L}+4 \\
\mathrm{H}-2 \rightarrow \mathrm{L}+2\end{array}$ \\
\hline
\end{tabular}




\section{Transient absorption Spectroscopy}
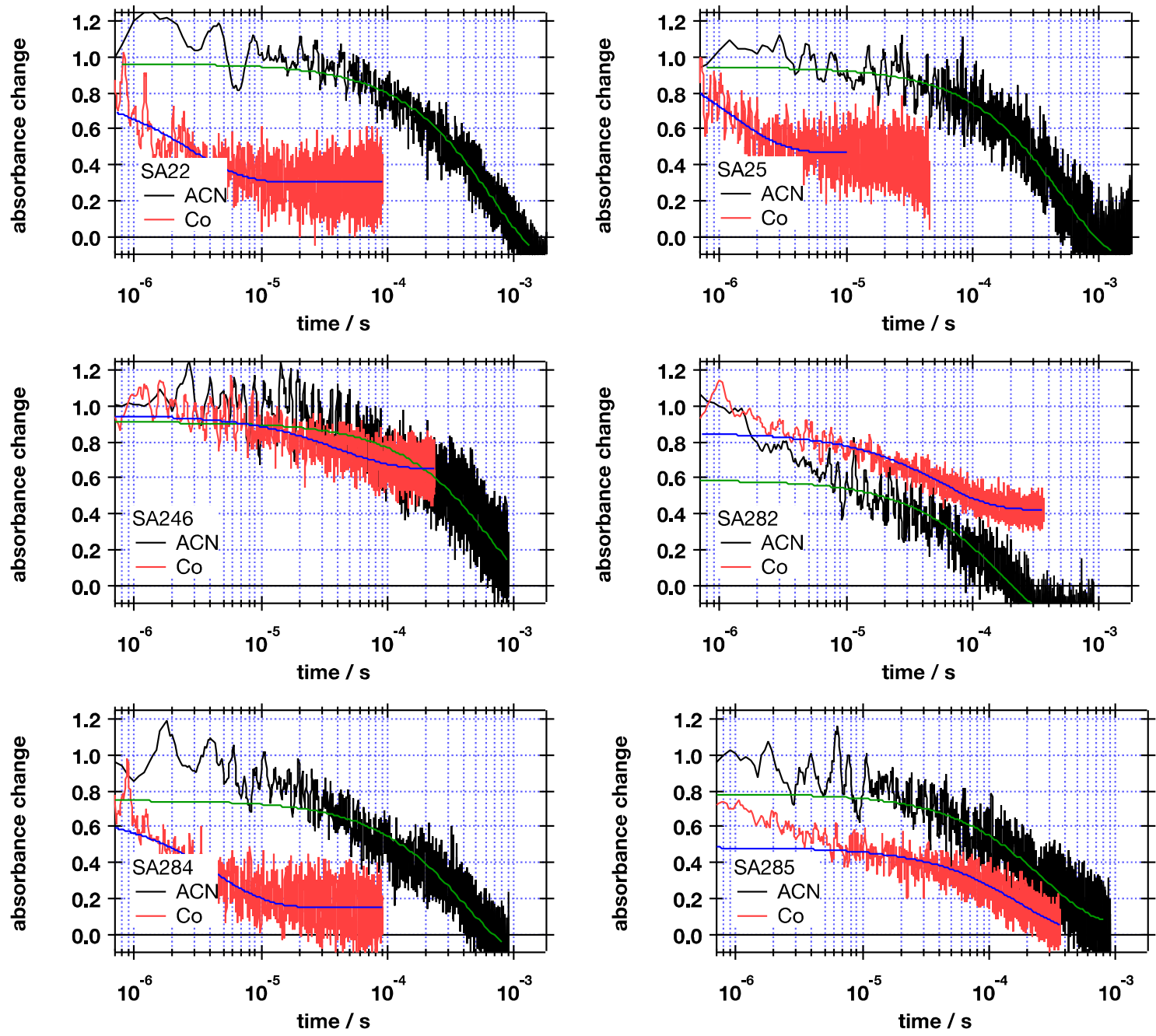

Figure S9. Nanosecond normalized transient absorbance decays of SA dyes at $900 \mathrm{~nm}$ in a DSC lacking (black) and containing (red) $\mathrm{Co}^{3+/ 2+}$ redox couple in the electrolyte.

In the devices with pure acetonitrile the only possible way of dye regeneration is back electron recombination, which is indicative of photooxidized dye lifetime.

Table S6. The Summary of TAS Analysis

\begin{tabular}{|l|c|c|c|}
\hline dye & $\begin{array}{c}\tau_{\text {rec }} \\
(\mu \mathrm{s})\end{array}$ & $\begin{array}{c}\tau_{\text {reg }} \text { (cobalt) } \\
(\mu \mathrm{s})\end{array}$ & $\eta_{\text {reg }}$ (cobalt) \\
\hline SA22 & 658 & 2.7 & 1 \\
\hline SA25 & 497 & 1.2 & 1 \\
\hline SA246 & 677 & 41 & 0.94 \\
\hline SA282 & 170 & 53 & 0.76 \\
\hline SA284 & 414 & 4.3 & 0.99 \\
\hline SA285 & 264 & 175 & 0.60 \\
\hline
\end{tabular}




\section{Electrochemical Impedance Spectroscopy}
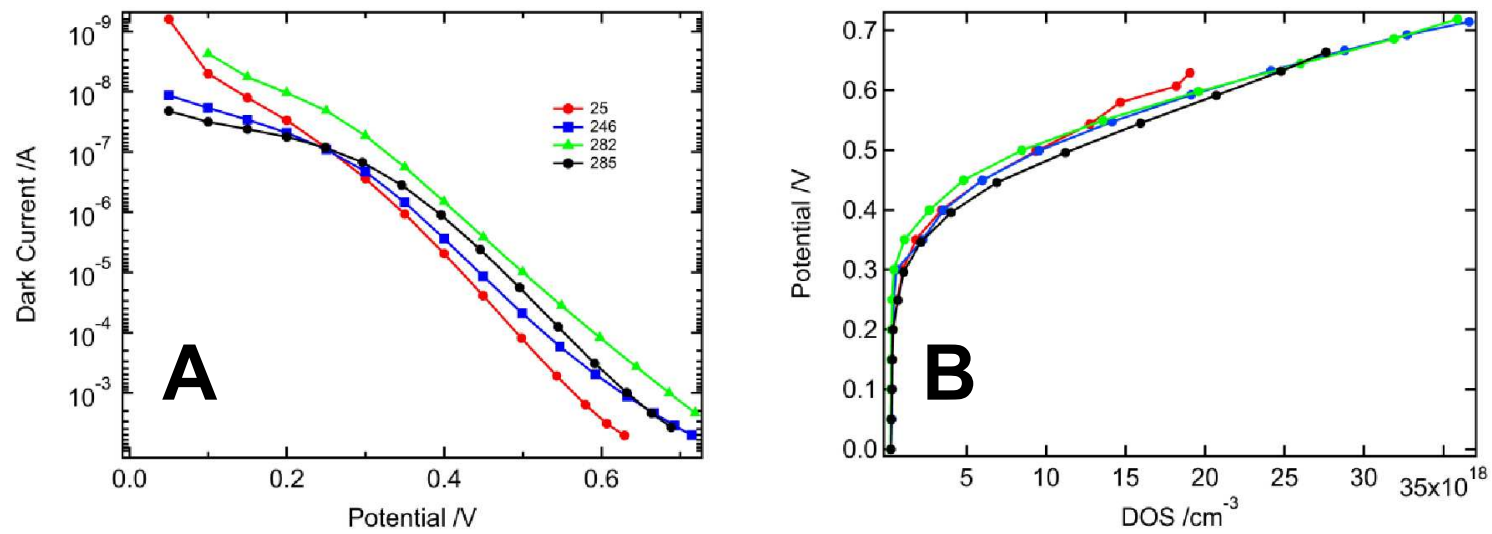

Figure S10. The key parameters extracted from EIS analyses of the iodine-based devices: (A) dark current over potential; (B) potential as a function of the density of states; In both figures, lines with red, blue, green and black colors refer to the devices with SA25, SA246, SA282 and SA285 respectively. 


\section{Photvoltaic Performance}
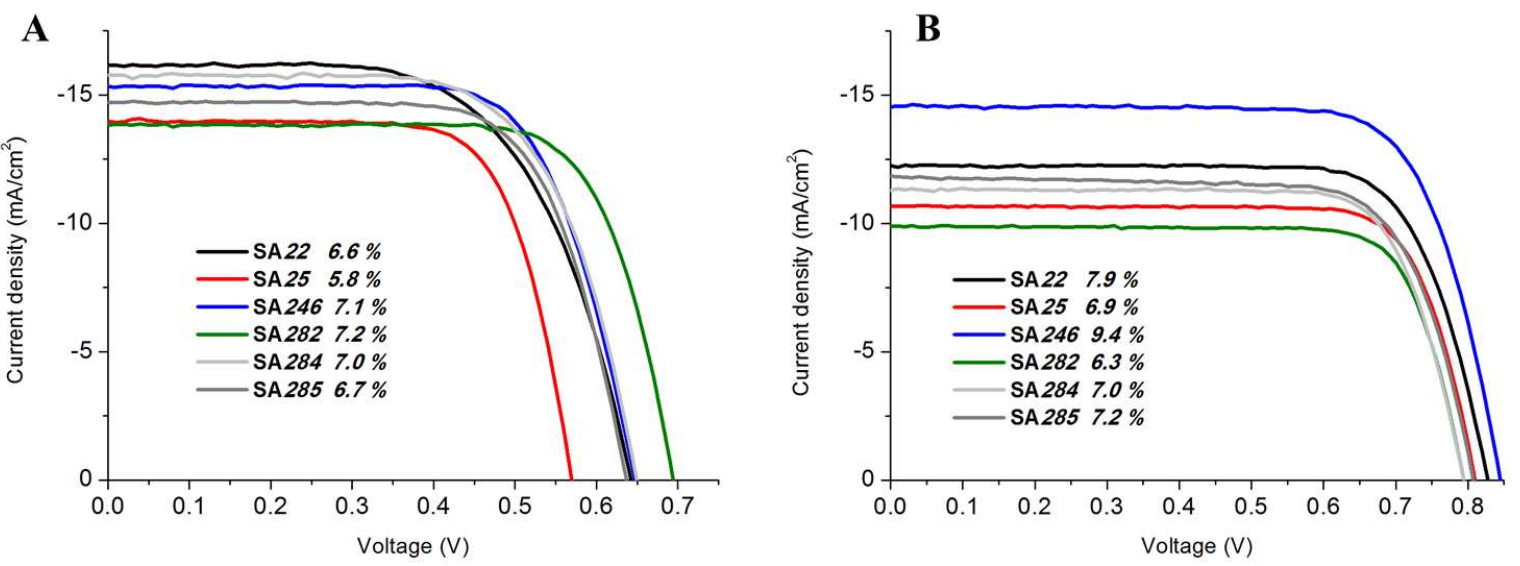

Figure S11. J-V curves of the devices with (A) iodine-based electrolyte and (B) cobalt-based electrolyte.

Table S7. Photovoltaic Performance of Iodine Based DSCs with SA Dyes

\begin{tabular}{|c|c|c|c|c|c|c|}
\hline${ }^{a}$ dye & Electrolyte & $\begin{array}{l}J_{S C} \\
\mathrm{~mA} / \mathrm{cm}^{2}\end{array}$ & $V_{O C}, \mathrm{mV}$ & $F F, \%$ & $\begin{array}{l}P C E(10 \\
\%)\end{array}$ & $\begin{array}{c}P C E \\
(100 \%)\end{array}$ \\
\hline SA22 & ${ }^{b} \mathrm{I}_{3}-/ \mathrm{I}^{-}$ & 16.16 & 642 & 62.4 & 6.8 & 6.6 \\
\hline SA25 & ${ }^{c} \mathrm{I}_{3}{ }^{-} / \mathrm{I}^{-}$ & 13.98 & 570 & 71.8 & 5.7 & 5.8 \\
\hline SA246 & ${ }^{c} \mathrm{I}_{3}^{-} / \mathrm{I}^{-}$ & 15.32 & 647 & 70.6 & 6.7 & 7.1 \\
\hline SA282 & ${ }^{c} \mathrm{I}_{3}^{-} / \mathrm{I}^{-}$ & 13.84 & 694 & 73.8 & 7.1 & 7.2 \\
\hline SA284 & ${ }^{b} \mathrm{I}_{3}^{-} / \mathrm{I}^{-}$ & 15.77 & 649 & 66.8 & 6.8 & 7.0 \\
\hline SA285 & ${ }^{c} \mathrm{I}_{3}{ }^{-} / \mathrm{I}^{-}$ & 14.71 & 634 & 69.9 & 6.9 & 6.7 \\
\hline \multicolumn{7}{|c|}{$\begin{array}{l}{ }^{a} \text { All cells were measured under AM 1,5 simulated solar light irradiation with power } 100 \mathrm{~mW} \mathrm{~cm}{ }^{-2} \text { at room temperature } \\
{ }^{b} \text { Iodine based electrolyte: } 1.0 \mathrm{M} \mathrm{1,3-propylmethylimidazolium} \mathrm{iodide} \mathrm{(PMII),} 100 \mathrm{mM} \mathrm{LiI}, 30 \mathrm{mM} \mathrm{I}, 0.5 \mathrm{M} \text { tert } \\
\text { butylpyridine (tBP) and } 0.1 \mathrm{M} \text { guanidinium thiocyanate (GNCS) in acetonitrile; }{ }^{c} \text { Iodine based electrolyte: } 1.0 \mathrm{M} \text { PMII, } 50 \\
\mathrm{mM} \mathrm{Lil,} 30 \mathrm{mM} \mathrm{I}, 20.5 \mathrm{M} \mathrm{tBP} \text { and } 0.1 \mathrm{M} \mathrm{GNCS} \mathrm{in} \mathrm{acetonitrile;}\end{array}$} \\
\hline
\end{tabular}




\section{References}

1. Polander, L. E.; Yella, A.; Curchod, B. F.; Ashari Astani, N.; Teuscher, J.; Scopelliti, R.; Gao, P.; Mathew, S.; Moser, J.-E. E.; Tavernelli, I.; Rothlisberger, U.; Grätzel, M.; Nazeeruddin, M. K.; Frey, J. Angew. Chem. Int. Ed. Engl. 2013, 52, 8731-8735.

2. Shavaleev, NM; Monti, F; Scopelliti, R; Baschieri, A., Sambri, L., Armaroli, N., Grätzel, M., Nazeeruddin, M. K.; Organometallics 2013, 32, 460-467.

3. Xia, C; Fan, X; Locklin, J; Advincula, RC. Organic letters 2002, 4, 2067-2070.

4. Tian, N.; Thiessen, A.; Schiewek, R.; Schmitz, O.J.; Hertel, D.; Meerholz, K.; Holder, E. J. Org. Chem. 2009, 74, 2718-2725.

5. Wu, K.L.; Li, C.H.; Chi, Y.; Clifford, J.N.; Cabau, L.; Palomares, E.; Cheng, Y-M.; Pan, H-A.; Chou, P-T. J. Am. Chem. Soc. 2012, 134, 7488-7496.

6. Yang, S.H.; Wu, K.L.; Chi, Y.; Cheng, Y-M.; Chou, P-T. Angew. Chem. Int. Ed. Engl. 2011, 50, 8270-8274.

7. Kim, J.-J. J.; Lim, K.; Choi, H.; Fan, S.; Kang, M.-S. S.; Gao, G.; Kang, H. S.; Ko, J. Inorg Chem. 2010, 49, 8357

8. Hai, J.; Zhu, E.; Bian, L.; Wang, J.; Wang, Z.; Li, Y.; Yin, L.; Zhang, F.; Tang, W. European Polymer Journal 2013, 49, 3610-3618.

9. Barlow, S.; Odom, S.A.; Lancaster, K.; Getmanenko, Y.A.; Mason, R.; Cocopceanu, V.; Brédas, J.-L.; Marder, S.R. J. Phys. Chem. B. 2010, 114, 14397-14407.

10. Brusso, J.; Hirst, O.; Dadvand, A.; Ganesan, S.; Cicoira, F.; Robertson, C.; Oakley, R.; Rosei, F.; Perepichka, D. Chemistry of Materials 2008, 20, 2484-2494.

11. Kawabata, K.; Takeguchi, M.; Goto, H. Macromolecules 2013, 46, 2078-2091.

12. Gao, F.; Wang, Y.; Zhang, J.; Shi, D.; Wang, M.; Humphry-Baker, R.; Wang, P.; Zakeeruddin, S.M.; Grätzel, M. Chem. Commun. 2008, 2635-2637.

13. Chen, C.-Y.; Wu, S.-J.; Wu, C.-G.; Chen, J.-G.; Ho, K.-C. Angew. Chem. Int. Ed. Engl. 2006, 45, $5822-5825$.

14. Ponomarenko, S.A.; Tatarinova, E.A.; Muzafarov, A.M.; Kirchmeyer, S.; Brassat, L.; Mourran, A.; Moeller, M.; Setayesh, S.; de Leeuw, D. Chem. Mater. 2006, 18, 4101-4108.

15. Kim, H.-S.; Kim, Y.-H.; Kim, T.-H.; Noh, Y.-Y.; Pyo, S.; Yi, M.H.; Kim, D.-Y.; Kwon, S.-K. Chem. Mater. 2007, 19, 3561-3567. 
16. Dudek, S.P.; Pouderoijen, M.; Abbel, R.; Schenning, A.P.H.J.; Meijer, E.W. J. Am. Chem. Soc. 2005, 127, 11763-11768.

17. Meng, Q.; Gao, J.; Li, R.; Jiang, L.; Wang, C.; Zhao, H.; Liu, C.; Li, H.; Hu, W. J. Mater. Chem. 2009, 19, 1477-1482.

18. Nusbaumer, H.; Zakeeruddin, S. M.; Moser, J. E.; Grätzel, M. Chemistry-A European Journal 2003, 9, 3756-3763.

19. Ito, S; Murakami, TN; Comte, P; Liska, P; Grätzel, C. Thin solid films 2009, 516, 4613-46119.

20. Frisch, M. J.; Trucks, G. W.; Schlegel, H. B.; Scuseria, G. E.; Robb, M. A.; Cheeseman, J. R.; Scalmani, G.; Barone, V.; Mennucci, B.; Petersson, G. A.; et. al., Gaussian, Inc., Wallingford CT, 2009.

21. Becke, A. D. J. Chem. Phys. 1993, 98, 1372-1377.

22. Binkley, J. S.; Pople, J. A.; Hehre, W. J. J. Am. Chem. Soc. 1980, 102, 939-947.

23. Godbout, N.; Salahub, D. R.; Andzelm, J.; Wimmer, E. Can. J. Chem. 1992, 70, 560-571.

24. Cossi, M.; Barone, V. J. Chem. Phys. 2001, 115, 4708-4717.

25. Cossi, M.; Barone, V.; Cammi, R.; Tomasi, J. Chem. Phys. Lett. 1996, 255, 327-335.

26. Mierts, S.; Scrocco, E.; Tomasi, J. J. Chem. Phys. 1981, 55, 117-129.

27. Isse, A. A.; Gennaro, A. J. Phys. Chem. B 2010, 114, 7894-7899. 